\title{
Analysis of the Lake Superior Watershed Seasonal Snow Cover
}

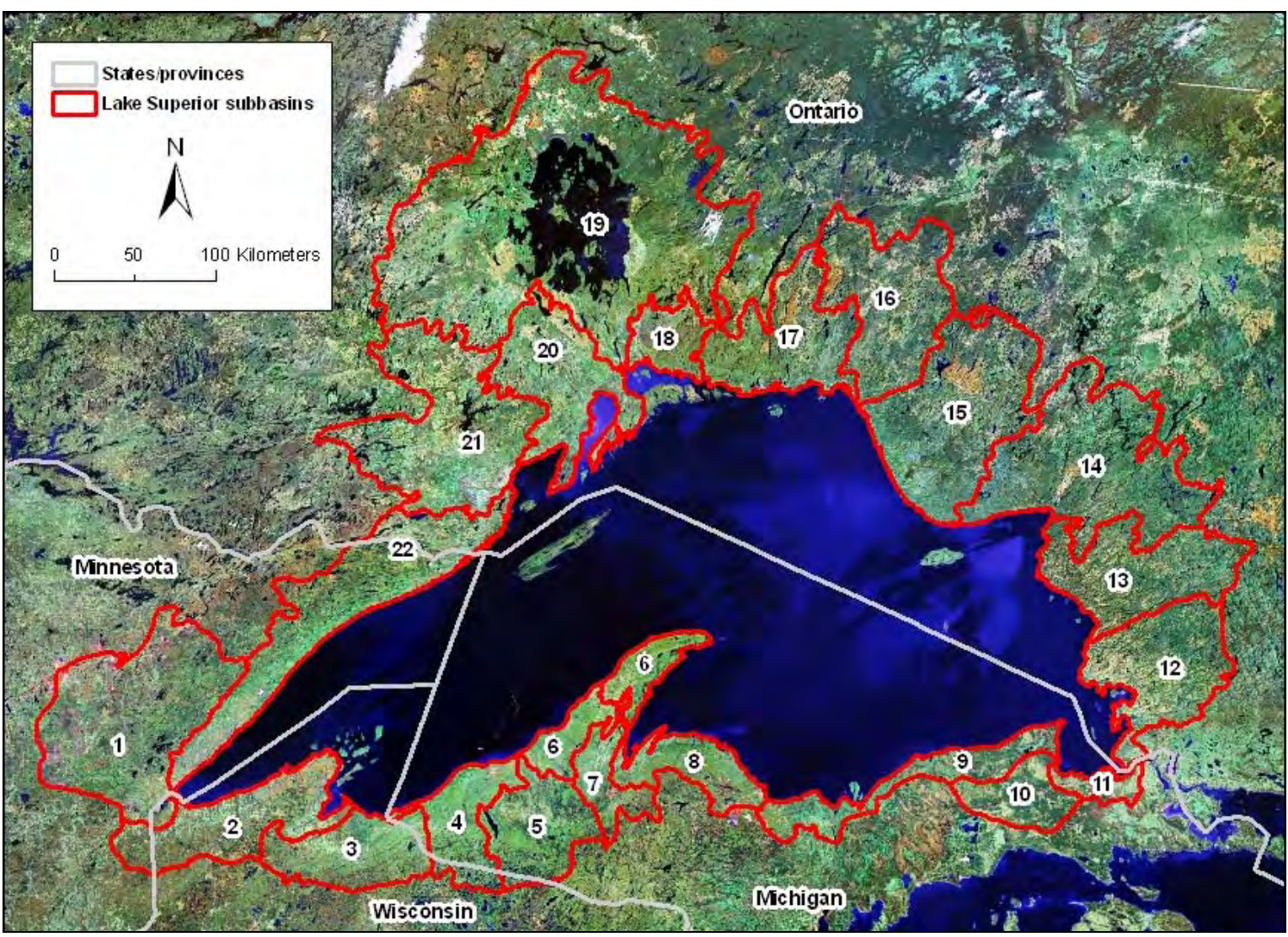




\section{Analysis of the Lake Superior Watershed Seasonal Snow Cover}

Steven F. Daly, Timothy B. Baldwin, and Patricia Weyrick

Cold Regions Research and Engineering Laboratory

U.S. Army Engineer Research and Development Center

72 Lyme Road

Hanover, NH 03755

Final report

Approved for public release; distribution is unlimited.

Prepared for Detroit District, U.S. Army Corps of Engineers 


\begin{abstract}
Daily estimates of the snow water equivalent (SWE) distribution for the period from 1 December through 30 April for each winter season from 1979- 80 through 2002- 03 were calculated for the entire Lake Superior watershed. The calculations were based on numerous groundbased daily observations collected and compiled by the National Weather Service in the United States and by the Meteorological Service of Canada in Canada. The daily estimates of SWE were then used to determine the annual accumulation and melt period characteristics of the Lake Superior watershed, along with the annual series of maximum SWE volume and the incremental accumulated SWE volume. Selected results are also shown for the individual sub-basins. Maps were also prepared of the mean SWE distributions on the $1^{\text {st }}$ and $15^{\text {th }}$ day of each winter month.
\end{abstract}

DISCLAIMER: The contents of this report are not to be used for advertising, publication, or promotional purposes. Citation of trade names does not constitute an official endorsement or approval of the use of such commercial products. All product names and trademarks cited are the property of their respective owners. The findings of this report are not to be construed as an official Department of the Army position unless so designated by other authorized documents. 


\section{Contents}

Figures and Tables................................................................................................................

Preface

1 Introduction

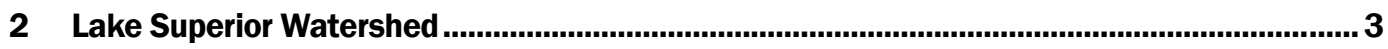

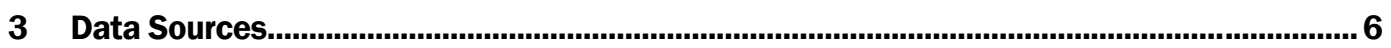

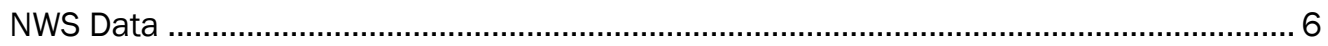

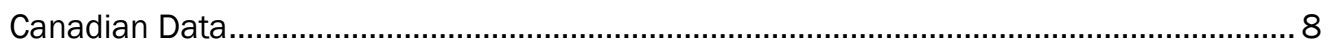

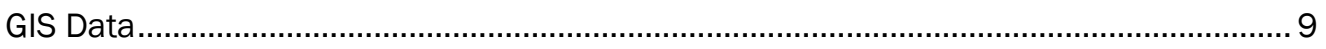

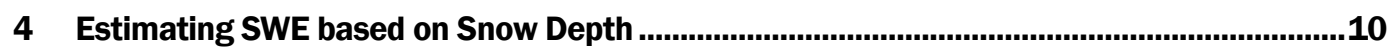

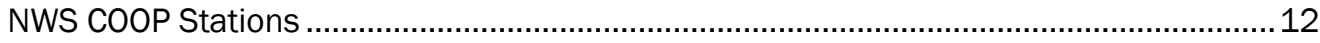

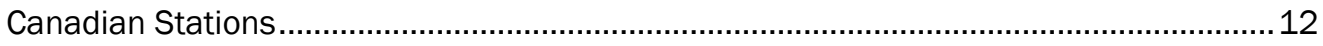

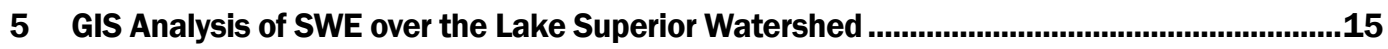

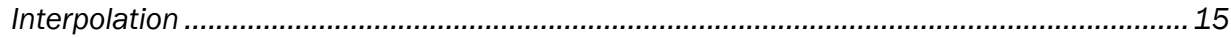

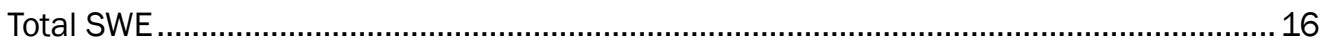

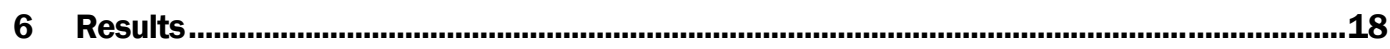

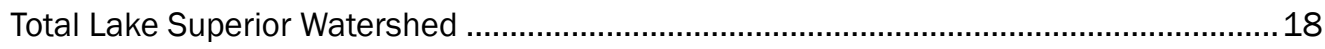

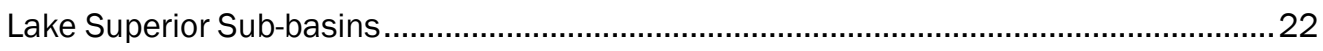

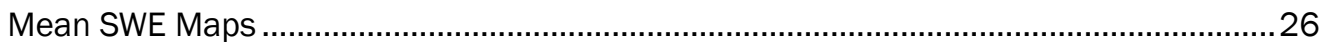

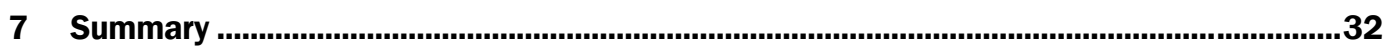

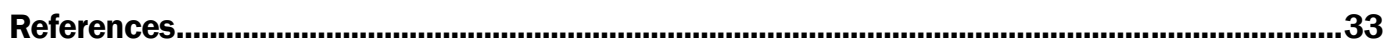

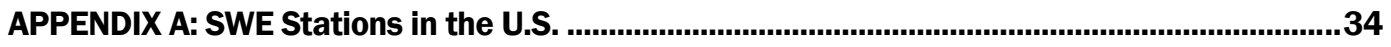

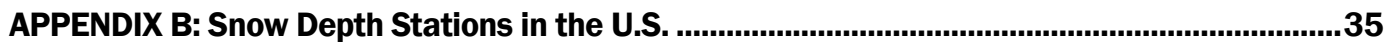

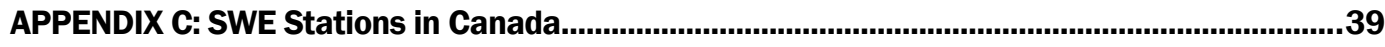

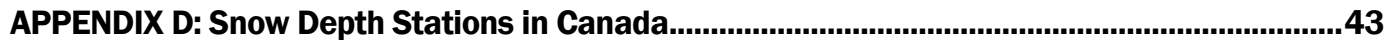

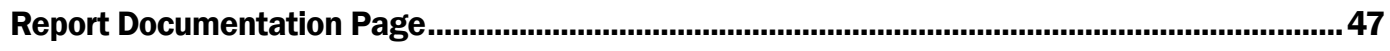




\section{Figures and Tables}

\section{Figures}

Figure 1. Lake Superior watershed ........................................................................................ 3

Figure 2. Lake Superior monthly water levels in meters from 1918 to 2005 .................................. 5

Figure 3. Stations providing snow information in the Lake Superior watershed ............................... 7

Figure 4. Number of observations stations reporting snow depth in the Lake Superior watershed and vicinity in Michigan, Minnesota, Wisconsin ......................................................... 7

Figure 5. Number of stations reporting snow information in the Lake Superior watershed and vicinity in Ontario, Canada.

Figure 6. Number of SWE observations by day of year in the Lake Superior watershed and vicinity in Ontario, Canada ................................................................................................ 9

Figure 7. Snow density by day of year at Sault Ste Marie, Duluth, and in the Lake Superior watershed and vicinity in Ontario, Canada

Figure 8. Snow density histogram for Sault Ste Marie, Ml; Duluth, MN; and in the Lake Superior watershed and vicinity in Ontario, Canada

Figure 9. ArcMap and the Gage Analyst extension were used to interpolate the March 15, 2001 SWE grid displayed in a grey-scale color ramp

Figure 10. Map showing SWE grid that is clipped to the Lake Superior watershed for 15 March 2001

Figure 11. Daily SWE volume for the entire Lake Superior watershed

Figure 12. Daily SWE statistics for the entire Lake Superior watershed 19

Figure 13. Maximum volume of SWE for the total Lake Superior watershed and the day of year when the maximum occurred

Figure 14. Accumulated SWE volume on the day of the maximum SWE volume, and accumulated SWE volume on 30 April plotted against the seasonal maximum SWE volume for each year

Figure 15. Maximum SWE volume, accumulated SWE volume on the day of the maximum SWE volume, and accumulated SWE volume on 30 April

Figure 16. Daily SWE volume for the Lake Superior sub-basins 22

Figure 17. Maximum SWE volume in $\mathrm{mm}$ for all 22 Lake Superior sub-basins 25 
Figure 18. Average and standard deviation of the maximum volume of SWE for the total Lake Superior watershed and the 22 sub-basins

Figure 19. Average day of year and standard deviation of the maximum volume of SWE for the total Lake Superior watershed and the 22 sub-basins

\section{Tables}

Table 1. Lake Superior sub-basin areas and maximum SWE values ................................................ 4

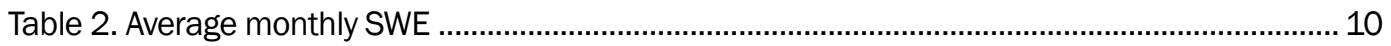

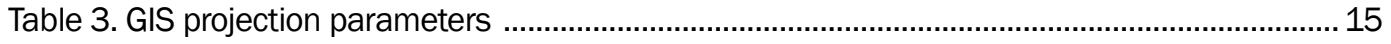

Table 4. Total Lake Superior and sub-basins annual maximum ........................................................ 23 


\section{Preface}

This report was prepared by Dr. Steven F. Daly, Timothy B. Baldwin, and Patricia Weyrick of the Remote Sensing/ GIS and Water Resources Branch of Cold Regions Research and Engineering Laboratory, U.S. Army Engineer Research and Development Center. This work was supported by the Detroit District of the Corps of Engineers. The participation of Keith Kompoltowicz of the Detroit District is gratefully acknowledged. Steven Newman and Elke Ochs of CRREL provided insight into available remote sensing technology and analysis.

The report was prepared under the general supervision of Timothy Pangburn, Chief, Remote Sensing/ GIS and Water Resources Branch; Dr. Lance Hansen, Deputy Director; and Dr. Robert E. Davis, Director, CRREL.

The Commander and Executive Director of ERDC is COL Richard B. J enkins. The Director is Dr. J ames R. Houston. 


\section{Introduction}

This report is an investigation of the historical spatial and temporal distribution of snow water equivalent (SWE) in the Lake Superior watershed. Lake Superior, the most upstream and largest of the Great Lakes, is an important water resource shared by Canada and the United States. The terrestrial and aquatic environments of the watershed, and the hydrology of the lake itself, are affected by the distribution of SWE and the rate of snow accumulation and ablation. Information on the volume of snowmelt inflow into Lake Superior is especially important in managing this valuable water resource. Snowmelt forms a portion of the total watershed runoff, which in turn, is a significant component of the total inflow into the lake, second only to the over-lake precipitation (Croley et al. 2001).

In this report we developed daily estimates of the SWE distribution each winter season from the winter of 1979- 80 through the winter of 2002- 03 for the entire Lake Superior watershed. Each winter season covered the period from 1 December through 30 April. These estimates were based on numerous ground-based daily observations collected and compiled by the National Weather Service (NOAA 2001, 2005) in the United States and compiled by the Meteorological Service of Canada in Canada (MSC 2000). The large majority of the observations were daily measurements of snow depth and not SWE. To make maximum use of the available snow observations, the SWE at each of these stations was estimated based on the observed snow depth and an estimated snow density. Different procedures were used to estimate the snow density in the U.S. and in Canada because of the very different observation protocols that were followed in each country. In both cases, if no observations of snow density were available within a specified distance and window of time around the snow depth observation, the long term monthly snow density was used. The long-term monthly snow density was estimated based on the historical data included in this study. Once the daily SWE had been estimated at every station the results could be interpolated throughout the Lake Superior watershed using inverse distance weighting. The end result was a series of gridded estimates of the daily SWE distribution covering the period of the study.

These gridded estimates of SWE were then used to estimate the total volume of SWE for each of the Lake Superior sub-basins and the entire wa- 
tershed for each day between 1 December and 30 April for the years 1980 through 2003. These results were then used to analyze the Lake Superior watershed seasonal snow cover. Results include the determining the annual accumulation and melt period characteristics, the annual series of maximum SWE volume, and comparing the annual maximum SWE volume with the incremental accumulated SWE volume. Selected results are also shown for the individual sub-basins. Maps were also prepared of the mean SWE distributions on the $1^{\text {st }}$ and $15^{\text {th }}$ day of each month. 


\section{Lake Superior Watershed}

Lake Superior is the largest of the Great Lakes, with a surface area of $83,400 \mathrm{~km}^{2}$ and a volume of approximately $12,100 \mathrm{~km}^{3}$ of water. This makes it the largest freshwater lake in the world by surface area and the third largest freshwater lake by volume. The Lake Superior watershed has an area of $211,400 \mathrm{~km}^{2}$ with $128,000 \mathrm{~km}^{2}$ of land surface (Fig. 1). The watershed covers portions of the province of Ontario, Canada, and portions of the states of Michigan, Wisconsin, and Minnesota in the United States. The Detroit District has conceptually divided the Lake Superior Watershed into 22 sub-basins with approximately half the sub-basins in each country. The area of each sub-basin is listed in Table 1.

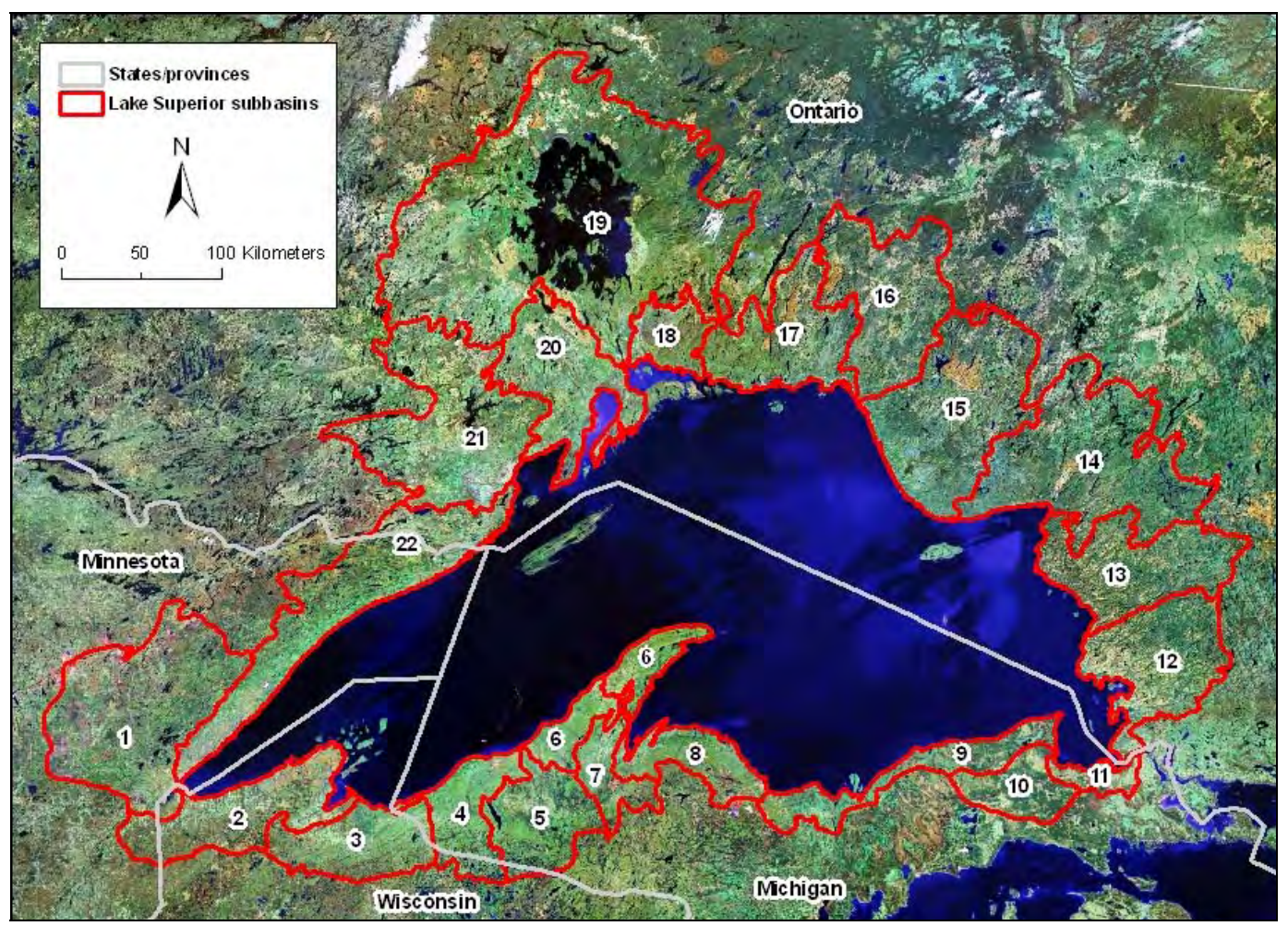

Figure 1. Lake Superior watershed.

The controlled outflow from Lake Superior is at the eastern end of the lake through the St. Marys River. The outflow from Lake Superior is controlled under stringent regulation plans agreed upon by Canada and the United States through the offices of the International J oint Commission (IJ C). Other components of the Lake Superior water balance, such as runoff, groundwater inflow, over-lake precipitation, and evaporation are not con- 
trolled (Neff and Nicholas 2004). The variations in these uncontrolled components, especially runoff, over-lake precipitation, and evaporation cause corresponding variations in the Lake Superior water levels. The record of monthly water levels for Lake Superior for the period from 1918 to the present is displayed in Figure 2. The water level of Lake Superior experiences short term, annual and long term changes. The short term changes, on the order of a few minutes to a few days, are caused by wind, waves, and seiches. The annual cycle is the result of the annual balance of inflows, outflows, and evaporation. The long term changes, on the order of years, result from the long term variations in the total precipitation, including snow fall, over the Lake Superior watershed (Croley et al. 2001).

Table 1. Lake Superior sub-basin areas and maximum SWE values.

\begin{tabular}{|c|c|c|c|}
\hline $\begin{array}{l}\text { Sub-Basin } \\
\text { Number }\end{array}$ & $\begin{array}{l}\text { Area } \\
\left(\mathrm{km}^{2}\right)\end{array}$ & $\begin{array}{l}\text { Average Annual Total Max. SWE } \\
\text { Volume } \times 10^{8}\left(\mathrm{~m}^{3}\right)\end{array}$ & $\begin{array}{l}\text { Average Annual Max. } \\
\text { SWE (mm) }\end{array}$ \\
\hline 1 & 9602 & 10.9 & 113.7 \\
\hline 2 & 4880 & 5.3 & 109.0 \\
\hline 3 & 3709 & 5.0 & 135.6 \\
\hline 4 & 2977 & 5.2 & 176.0 \\
\hline 5 & 3664 & 6.1 & 165.8 \\
\hline 6 & 2887 & 5.7 & 198.1 \\
\hline 7 & 1775 & 3.5 & 200.0 \\
\hline 8 & 2543 & 5.4 & 212.8 \\
\hline 9 & 3076 & 6.5 & 212.9 \\
\hline 10 & 2137 & 3.8 & 176.6 \\
\hline 11 & 842 & 1.4 & 166.9 \\
\hline 12 & 5299 & 11.5 & 217.7 \\
\hline 13 & 5579 & 12.0 & 215.4 \\
\hline 14 & 9516 & 18.1 & 190.3 \\
\hline 15 & 8350 & 12.1 & 145.2 \\
\hline 16 & 6439 & 8.8 & 136.4 \\
\hline 17 & 5079 & 6.8 & 133.2 \\
\hline 18 & 1894 & 2.4 & 126.5 \\
\hline 19 & 25601 & 32.3 & 126.0 \\
\hline 20 & 5389 & 5.8 & 107.2 \\
\hline 21 & 8775 & 10.1 & 115.3 \\
\hline 22 & 8011 & 10.6 & 132.2 \\
\hline
\end{tabular}




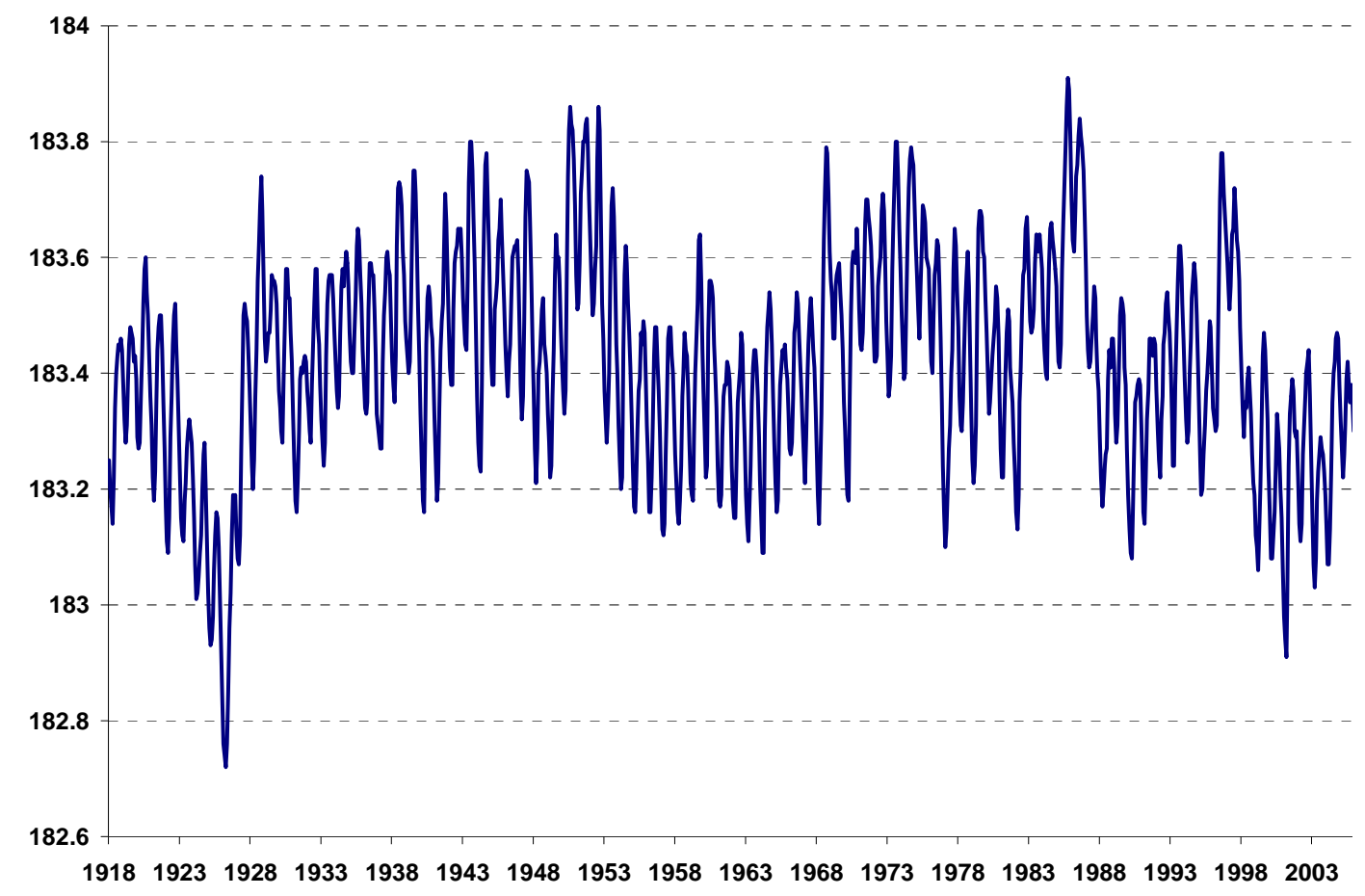

Figure 2. Lake Superior monthly water levels in meters from 1918 to 2005 (International Great Lakes Datum 1985).

The International Lake Superior Board of Control, with members from both countries, was established by the IJ C in 1914 to control and regulate the outflow of Lake Superior through the St Marys River. The regulations acknowledge the needs of various interest groups on Lake Superior and the St. Marys River, including navigation, hydropower, and riparian owners. As described by the Board:

"The main objective of the present regulation plan is to determining (sic) a flow that will bring the levels of Lake Superior and Lakes Michigan and Huron to nearly the same relative position within their respective ranges of actual historic levels. At the same time, the plan tries to prevent the level of Lake Superior from rising above or falling below certain water levels specified in the Order. The plan also contains provisions to safeguard against high levels in the harbor below the locks, provides a fixed minimum release, limits winter flows, and employs a forecast of future water supply conditions" (IJ C 2006). 


\section{Data Sources}

The total daily volume of SWE for the Lake Superior watershed was determined based on the observed snow data for the years 1979 through 2004. Canadian data were actually only available up to 2003 and determined the last year for which the total SWE for Lake Superior could be estimated. Data for the United States were collected and compiled by the NWS (NOAA 2001, 2005). Data for Canada was available from the Canadian Snow Data CD-ROM (MSC 2000). The overwhelming majority of U.S. and Canadian stations included in this study reported only a daily snow depth. These snow depths observations were used to estimate the corresponding daily SWE at each station by multiplying the observed snow depth by an estimated snow density. The procedure used to estimate the snow density is described in the next section. Once the daily SWE had been estimated at all the stations for which data were available in the Lake Superior watershed, the distribution of SWE over the entire Lake Superior watershed was estimated by interpolating the observed and estimated SWE data. The GIS coverages used in the interpolation process are described in this section and the GIS procedures used are described in a following section.

\section{NWS Data}

The NWS snow data (NOAA 2001, 2005) consisted of daily observations of snow depths at COOP stations and daily observations of snow water equivalent (SWE) and snow depth at the two first order stations located in the Lake Superior watershed (Fig. 3). This study included all COOP stations located within the Lake Superior watershed and within $60 \mathrm{~km}$ of the watershed boundary. The NWS stations used in this study are listed in Appendix A and Appendix B. Descriptive data available for each station included the latitude, longitude, elevation and period of record. The number of COOP stations providing snow depth data varied from day to day and year to year as shown in Figure 4. In general, more stations provided snow observation data in the winter than in the summer. The summer observations, when available, were uniformly zero depth, as expected. The number of stations providing data on any one day ranged from a maximum of about 100 to a low of about 65. The number of COOP stations providing useable snow depth observations dropped sharply in the winter of 200102. The number of stations recovered somewhat by the winter of 2003- 04 . 


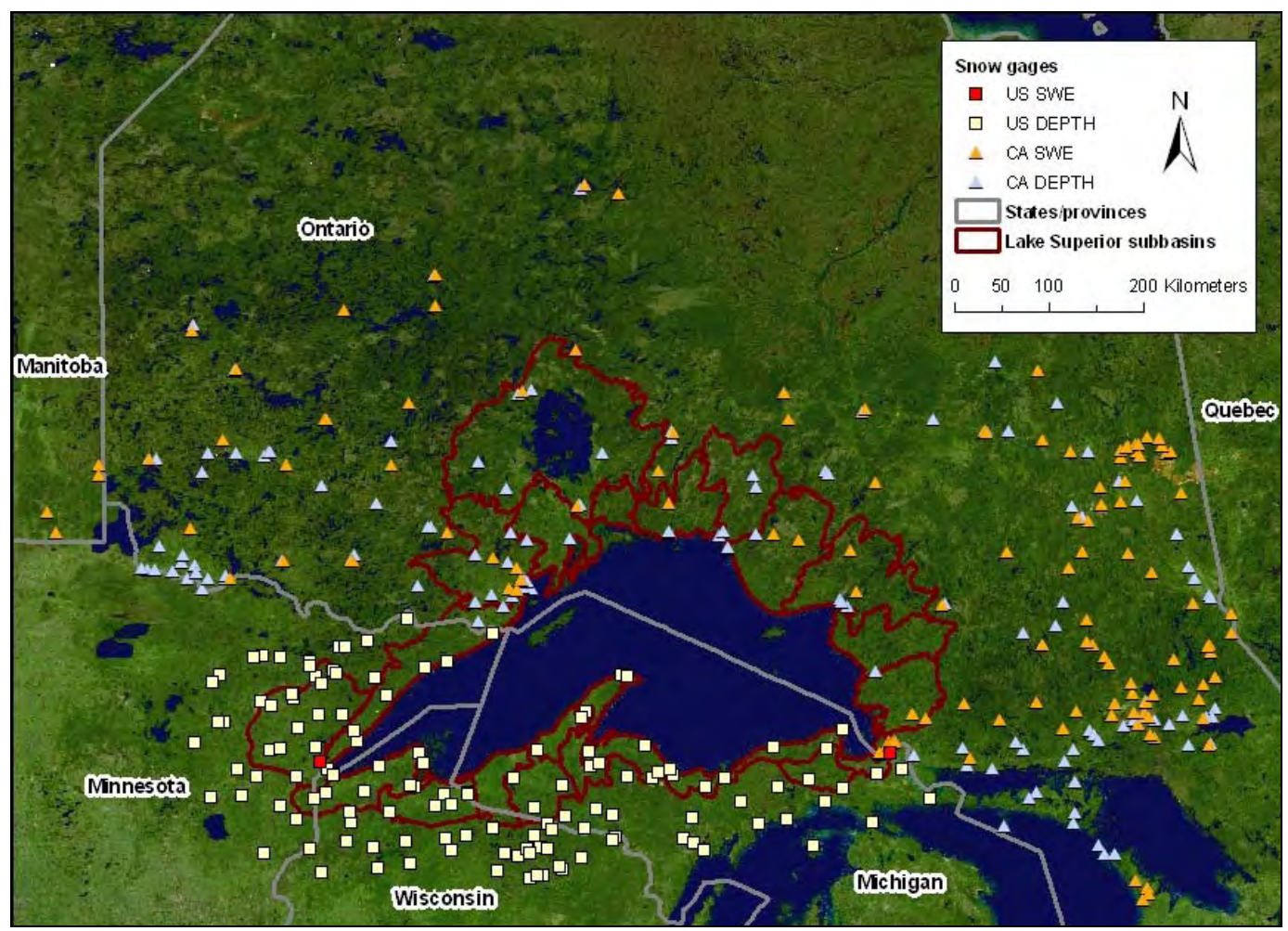

Figure 3. Stations providing snow information in the Lake Superior watershed.

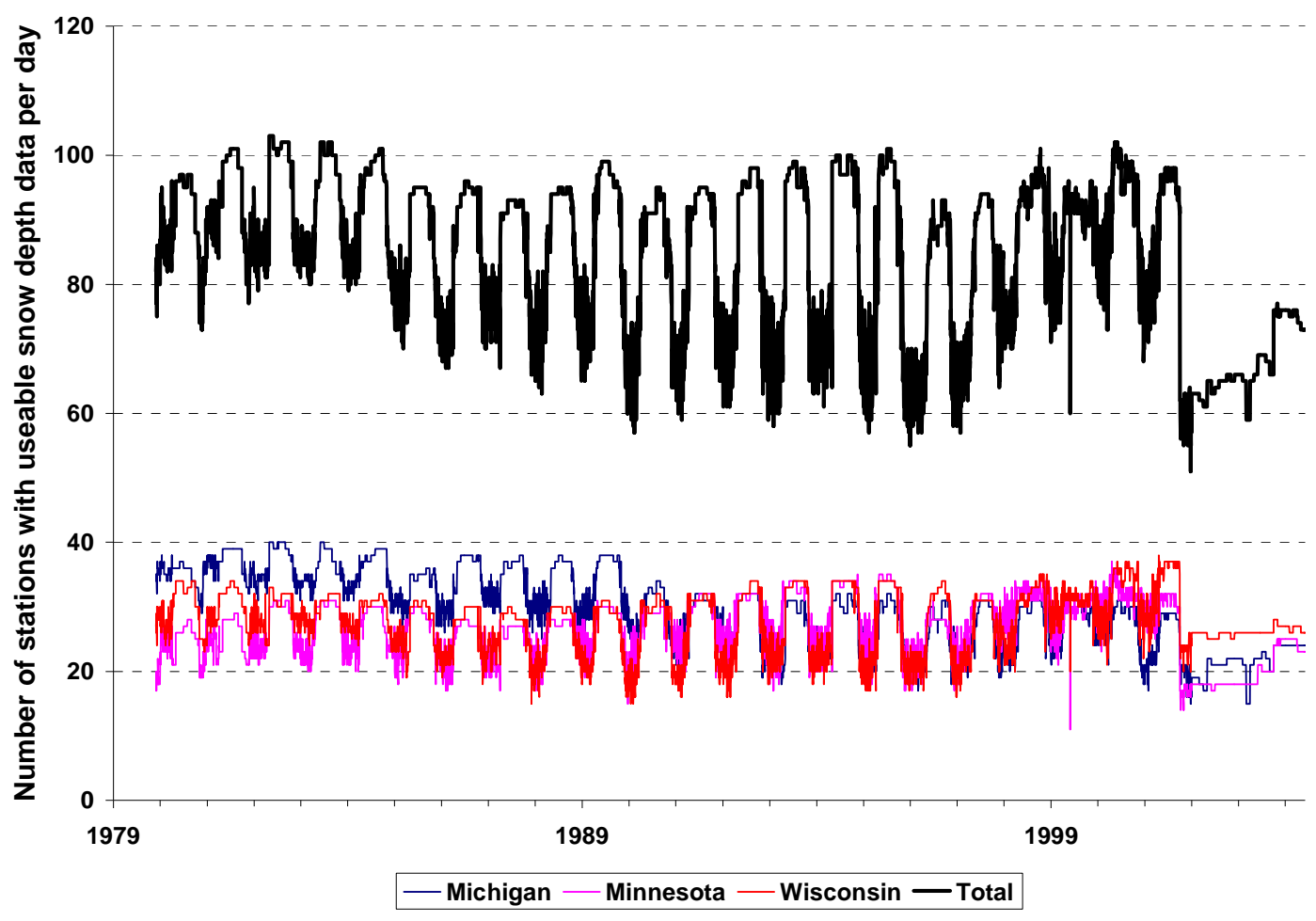

Figure 4. Number of observations stations reporting snow depth in the Lake Superior watershed and vicinity in Michigan, Minnesota, Wisconsin 


\section{Canadian Data}

The Canadian Snow Data CD-ROM included the Canadian Daily Snow Depth Database and the Canadian Snow Water Equivalent Database (MSC 2000). The Daily Snow Depth Database consists of daily and weekly snow depth observations taken by the Meteorological Service of Canada. The Snow Water Equivalent Database contains SWE and snow depth measurements from snow surveys taken by more than 20 agencies weekly, biweekly or monthly. It also contains biweekly SWE estimates at Meteorological Service of Canada snow depth observing stations. Descriptive data available for each station in both databases included the latitude, longitude, elevation, and period of record. This study included all snow depth and SWE observations located within the Lake Superior watershed and within $300 \mathrm{~km}$ of the watershed boundary (Fig. 5). The Canadian stations used in this study are listed in Appendix C and Appendix D. The number of snow depth observations varied from day to day and year to year, as shown in Figure 5. The number of daily observations reported declined steadily since the early 1980s. The snow observations included in the Snow Water Equivalent Database were generally not made daily but rather on the $1^{\text {st }}$ and $15^{\text {th }}$ day of each winter month (Fig. 6).

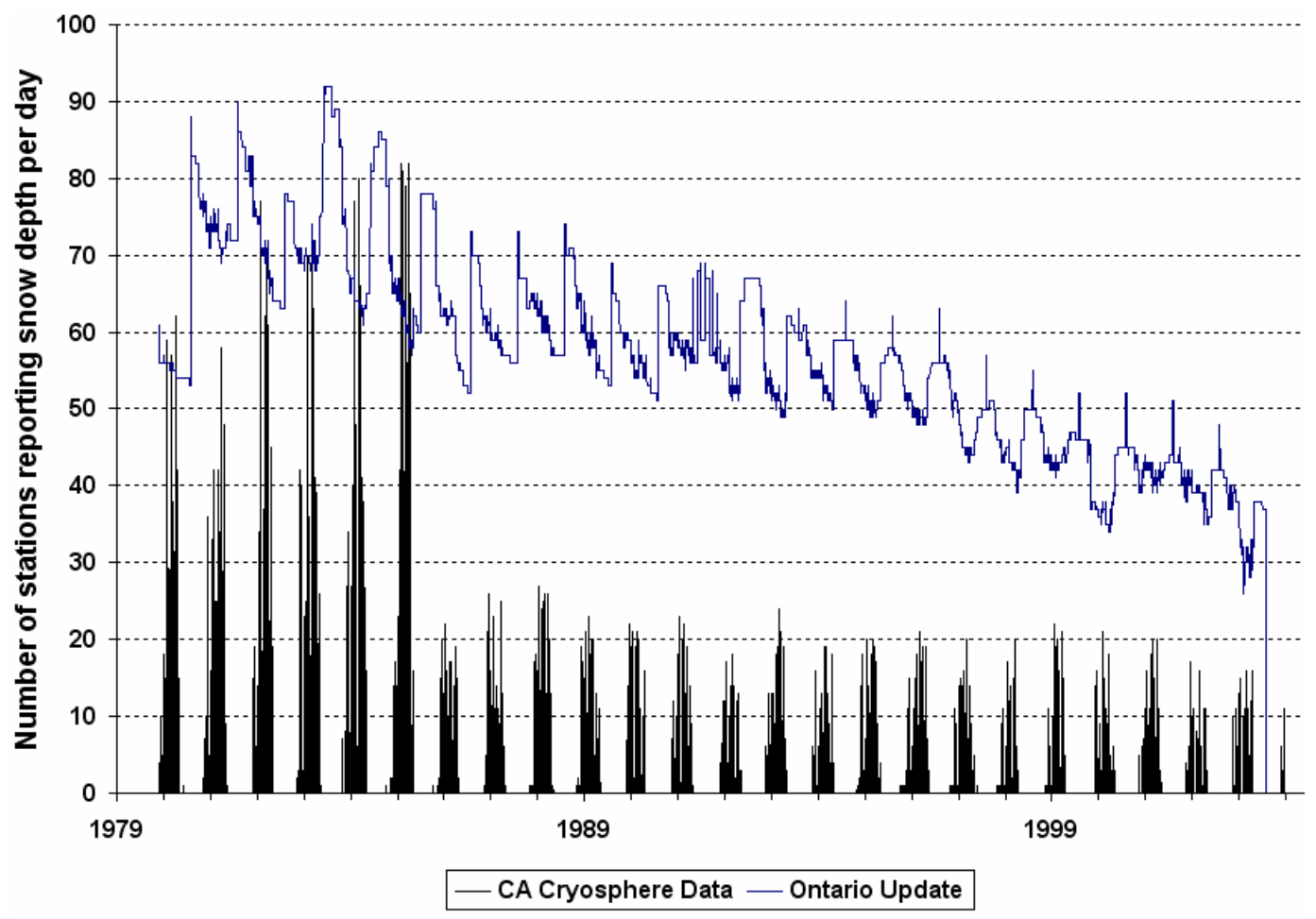

Figure 5. Number of stations reporting snow information in the Lake Superior watershed and vicinity in Ontario, Canada. 


\section{GIS Data}

The two main GIS layers that were used in the analysis were a gage layer and a sub-basin layer. A gage GIS layer was created from the latitude and longitude values that came with the Canadian and United States gage snow observation data. On the US side, gages were only used if they were located within $60 \mathrm{~km}$ of the Lake Superior Basin. For the Canadian side, gages were kept if they were within $300 \mathrm{~km}$ of the basin. The gage layer was used to interpolate values across the study area.

The second GIS layer used in computations represented the 22 sub-basins in the Lake Superior basin. This sub-basin layer was obtained from U.S. Army Engineer District, Detroit. It was used to clip the interpolated SWE grids that were created to the Lake Superior basin boundary. Additionally, it was used to calculate the total SWE in each sub-basin for each day that was run.

In addition to the layers used in the GIS analysis itself, additional background data were used in the figures and maps that were created. Most of these layers came from ESRI (ESRI 2005). In addition to the ESRI data, a political boundaries layer of North America was used that was downloaded from the USGS (USGS 2006).

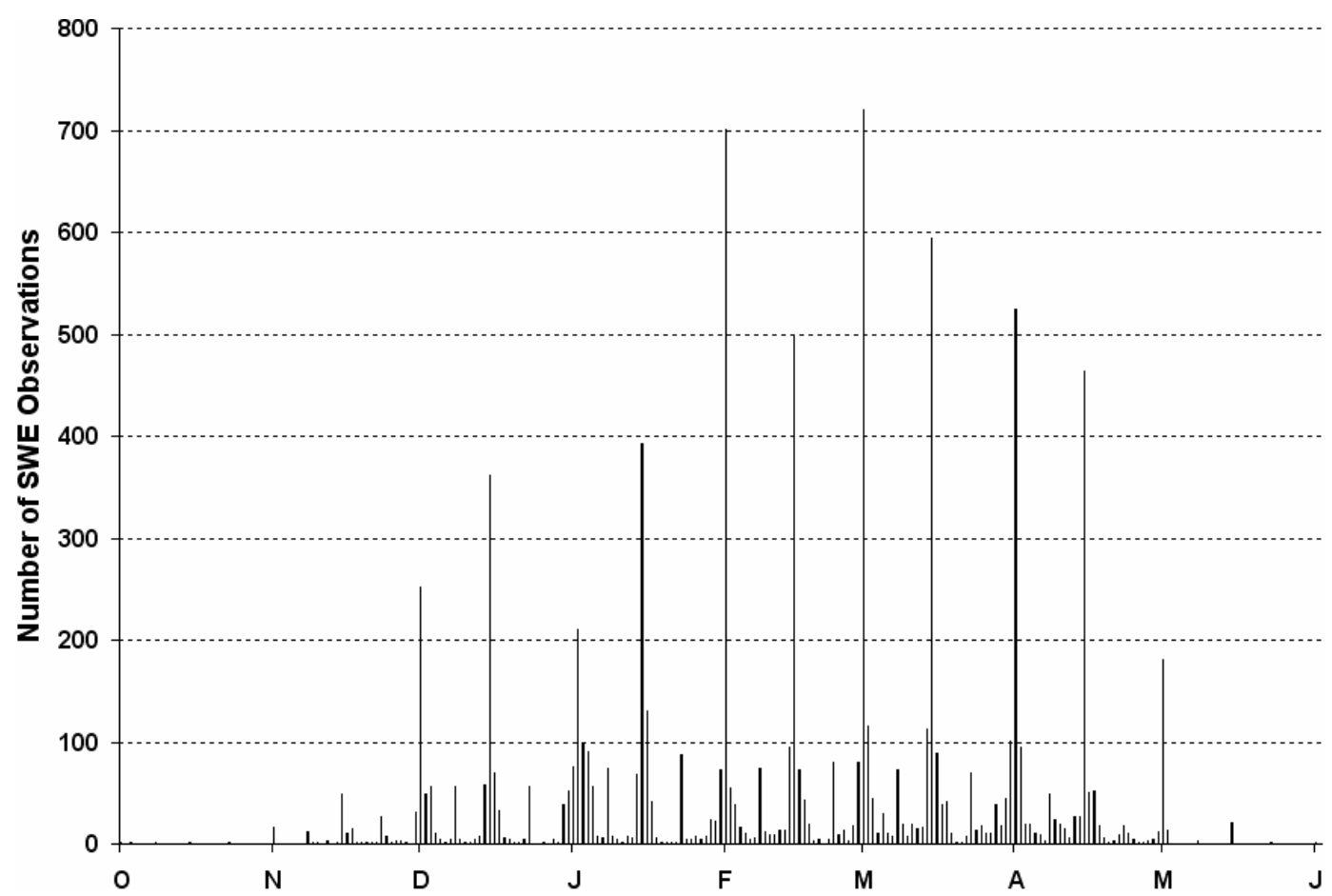

Figure 6. Number of SWE observations by day of year in the Lake Superior watershed and vicinity in Ontario, Canada. 


\section{Estimating SWE based on Snow Depth}

The large majority of observations included in this study were of snow depth and not SWE. Estimations of SWE can be made based on snow depth if the snow density can be estimated. Snow density (the ratio of the snow mass to volume) can vary widely and it is not appropriate to use a fixed value. The density of new-fallen snow depends on the air temperature, humidity, and wind speed. Once on the ground, the density of snow increases via crystal metamorphism, settlement, and wind packing. Snow density can also vary with depth, with snow near the bottom of snowpacks tending to be denser than that near the top. Daily estimates of the depthaveraged snow density can be made at observation stations that report both the snow depth and SWE based on the conservation of total water

$$
\bar{\rho}_{\mathrm{s}}=\rho_{\mathrm{w}} \frac{S W E}{d_{\mathrm{s}}}
$$

where

$$
\begin{aligned}
\bar{\rho}_{\mathrm{s}} & =\text { depth-averaged snow density } \\
\rho_{\mathrm{w}} & =\text { water density } \\
\mathrm{SWE} & =\text { observed SWE depth } \\
\mathrm{d}_{\mathrm{s}} & =\text { snow depth. }
\end{aligned}
$$

Table 2. Average monthly SWE $\left(\mathrm{kg} / \mathrm{m}^{3}\right)$.

\begin{tabular}{|l|c|c|c|}
\hline Month & Duluth, MN & Sault Ste. Marie, MI & Canadian Data \\
\hline NOV & 150 & 110 & 180 \\
\hline DEC & 170 & 130 & 180 \\
\hline JAN & 160 & 190 & 190 \\
\hline FEB & 190 & 240 & 210 \\
\hline MAR & 280 & 330 & 250 \\
\hline APR & 350 & 430 & 300 \\
\hline
\end{tabular}

The monthly average snow densities, based on all years of record, for Duluth, Sault Ste. Marie, and Canada are listed in Table 2. The observed snow density at all the stations where SWE and snow depth observations were available are shown in Figures 7, based on the day of the winter. A histogram of the distribution of snow density values throughout the year is 
shown in figure 8. In general, the observations of SWE at Duluth and Sault Ste. Marie in the U.S. and at all the Canadian observation stations are consistent. All show a general increase throughout the winter.

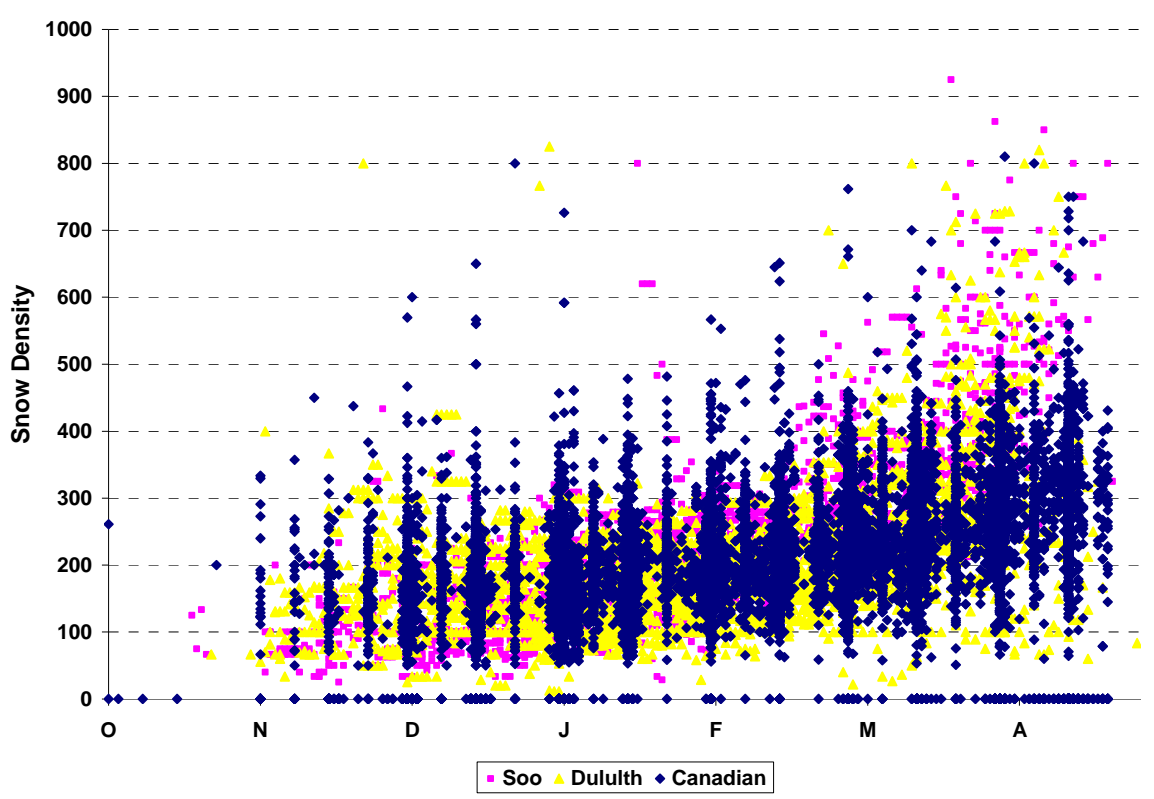

Figure 7. Snow density $\left(\mathrm{kg} / \mathrm{m}^{3}\right)$ by day of year at Sault Ste Marie (Soo), Duluth, and in the Lake Superior watershed and vicinity in Ontario, Canada.

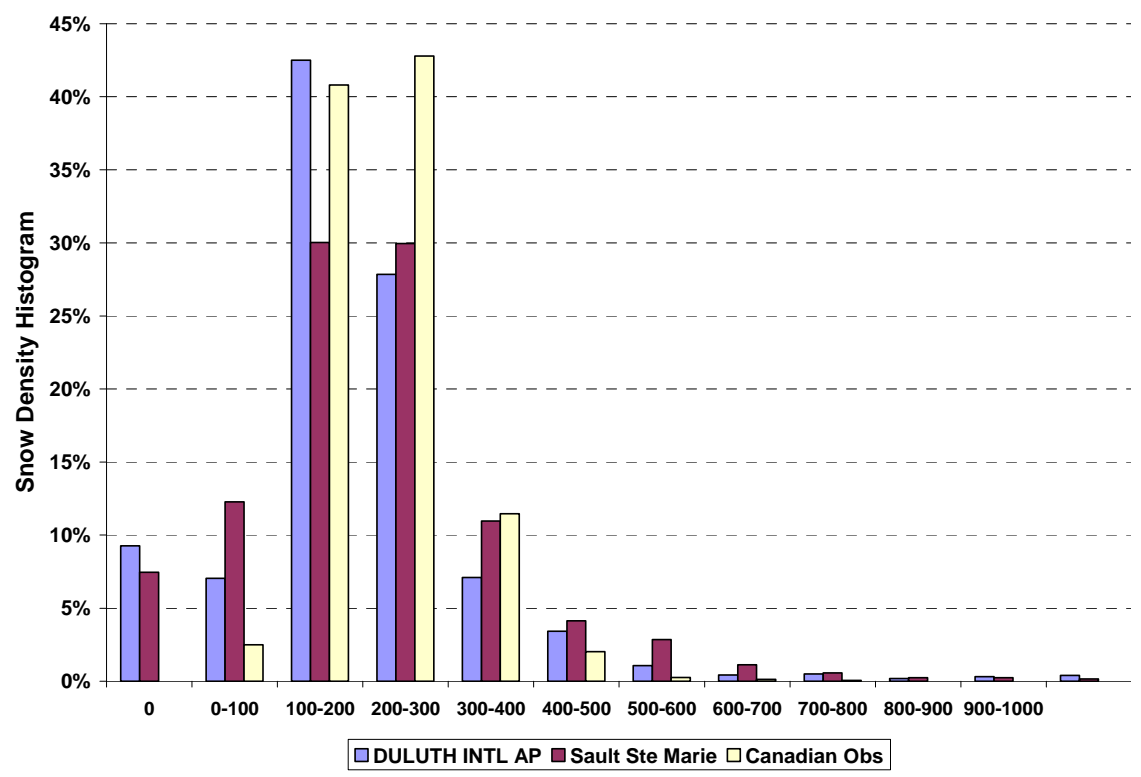

Figure 8. Snow density histogram $\left(\mathrm{kg} / \mathrm{m}^{3}\right)$ for Sault Ste Marie (Soo), MI; Duluth, MN; and in the Lake Superior watershed and vicinity in Ontario, Canada.

The following procedure was followed to estimate SWE at all the gages where snow depth observations were available. 


\section{NWS COOP Stations}

The SWE at the NWS COOP stations was estimated by assuming that the snow density at each COOP station could be approximated by the observed snow density at the closer of the two U.S. NWS stations where SWE was observed on the same date. To start, the distance between each COOP station and the two U.S. NWS stations where SWE was observed, Duluth or Sault Ste. Marie, was calculated and the closest station selected. Then the $S W E$ at a COOP station number $k$ on day $j, S W E_{j}^{k}$, was estimated by rearranging eq 1 for SWE and then substituting the observed snow density

$$
S W E_{\mathrm{j}}^{\mathrm{k}}=d_{\mathrm{sj}}^{\mathrm{k} j} \frac{\bar{\rho}_{\mathrm{sj}}^{\mathrm{k}}}{\rho_{\mathrm{w}}}=d_{\mathrm{sj}}^{\mathrm{k}} \frac{S W E_{\mathrm{j}}}{d_{\mathrm{sj}}}
$$

where

$$
\begin{aligned}
d_{\mathrm{s} j}^{\mathrm{k}}= & \text { snow depth observation at COOP station number } \mathrm{k} \text { on day } \mathrm{j} \\
\bar{\rho}_{\mathrm{s} j}^{\mathrm{k}}= & \text { unknown snow density at COOP station number } \mathrm{k} \text { on day } \mathrm{j} \\
\mathrm{d}_{\mathrm{sj}}= & \text { snow depth at the closer SWE observation station, either } \\
& \text { Duluth or Sault Ste. Marie, on day } \mathrm{j} \\
\mathrm{SWE}_{\mathrm{j}}= & \text { SWE at the closer SWE observation station, either Duluth or } \\
& \text { Sault Ste. Marie, on day j. }
\end{aligned}
$$

If the snow depth observation at the COOP station was missing, the corresponding SWE observation was set as missing as well. If either the SWE observation or the snow depth observation was missing at the SWE observation station, or if the ratio of SWE to snow depth was greater than 0.8 at the SWE observation station, the appropriate monthly mean snow density at the snow observation station (Table 2) was used to estimate $S W E_{\mathrm{j}}^{\mathrm{k}}$ as

$$
S W E_{\mathrm{j}}^{\mathrm{k}}=d_{\mathrm{s} \mathrm{j}}^{\mathrm{k}} \frac{\bar{\rho}_{\text {smonthly }}}{\rho_{\mathrm{w}}} .
$$

\section{Canadian Stations}

The Canadian observations differed from the U.S. observation in that there were many more stations that measured SWE directly, but almost all of these SWE observations were done bi-monthly or monthly and not daily. These stations are included in the Canadian Snow Water Equivalent Database did not need to have SWE estimated because the SWE had been 
measured in the field. These measurements also included snow depth and, as a result, these data could be used to estimate the depth-averaged snow density using eq 1 . The density could be estimated on each day that measurements had been made, generally once or twice a month. Only at the stations where snow depth alone was measured was it necessary to estimate SWE. These stations are included in the Canadian Daily Snow Depth Database and the large majority of these stations had daily observations of snow depth.

The following procedure was used to estimate SWE. First, the distances between each snow depth station and all the stations where SWE had been measured were calculated and the three closest SWE stations selected. Each of the three closest SWE stations generally provided only one or two estimates of snow density a month, and usually the measurements were not made at all three stations on the same day. A centered 15-day moving average of SWE and snow depth for each of these stations was used to compensate for the sparseness in time of the measurements and the lack of synchronicity between stations. These three averaged SWE and snow depths were then used to estimate the snow density at each snow depth station. The snow density on day $\mathrm{j}$ at the snow depth observation station $\mathrm{k}, \rho_{\mathrm{snowj}}^{\mathrm{k}}$, was estimated using inverse distance squared weighting

$$
\rho_{\text {snow j }}^{\mathrm{k}}=\rho_{\mathrm{w}} \frac{\sum_{m=1}^{n} \frac{1}{L_{\mathrm{k}-\mathrm{m}}^{2}} \frac{S W E_{15 \mathrm{j}}^{\mathrm{m}}}{d_{15 \mathrm{j}}^{\mathrm{m}}}}{\sum_{m=1}^{n} \frac{1}{L_{\mathrm{k}-\mathrm{m}}^{2}}}
$$

where

$\mathrm{L}_{\mathrm{k}-\mathrm{m}}=$ distance from the snow depth observation station $\mathrm{k}$ to SWE observation station $\mathrm{m}$

$S W E_{15 \mathrm{j}}^{\mathrm{m}}=15$-day moving average SWE at station $\mathrm{m}$ on day $\mathrm{j}$

$d_{15 \mathrm{j}}^{\mathrm{m}}=15$-day moving average snow depth at station $\mathrm{m}$ on day $\mathrm{j}$

$\mathrm{n}=$ the number of SWE observation stations with valid information $(0 \leq n \leq 3)$.

The snow density was not allowed to change by more than 0.05 from one day to the next. The SWE was then estimated as 


$$
S W E_{\mathrm{j}}^{\mathrm{k}}=d_{\mathrm{sj}}^{\mathrm{k}} \frac{\rho_{\text {snow j }}^{\mathrm{k}}}{\rho_{\mathrm{w}}}=d_{\mathrm{s} \mathrm{j}}^{\mathrm{k}} \frac{\sum_{m=1}^{n} \frac{1}{L_{\mathrm{k}-\mathrm{m}}^{2}} \frac{S W E_{15 \mathrm{j}}^{\mathrm{m}}}{d_{15 \mathrm{j}}^{\mathrm{m}}}}{\sum_{m=1}^{n} \frac{1}{L_{\mathrm{k}-\mathrm{m}}^{2}}}
$$

Once the snow density had been calculated, it was assumed to hold for 32 days, unless another valid snow density was estimated. After 32 days or if no valid snow densities had been estimated, the appropriate Canadian monthly mean snow density (Table 2) was used to estimate $S W E_{\mathrm{j}}^{\mathrm{k}}$ as

$$
S W E_{\mathrm{j}}^{\mathrm{k}}=d_{\mathrm{sj}}^{\mathrm{k}} \frac{\rho_{\mathrm{s} \text { monthly }}}{\rho_{\mathrm{w}}}
$$

As with the U.S. stations, if the daily snow depth observation was missing, the corresponding SWE observation was set as missing as well. If either the 15-day moving average SWE observation or the 15-day moving average snow depth observation was missing at the SWE observation station, or if the ratio of 15-day moving average SWE to 15-day moving average snow depth was greater than 0.8 at the SWE observation station, then the SWE observation was set to missing. 


\section{GIS Analysis of SWE over the Lake Superior Watershed}

After the SWE had been calculated for all stations that only had snow depth measurements, the next step was to interpolate the SWE for these stations along with the stations that directly measured SWE across the study area. The GIS software used to perform the GIS analysis was ESRI's ArcGIS software package, version 9.1. The projection that was used for this study was an Albers equal area projection that ESRI refers to as “USA_Contiguous_Albers_Equal_Area_Conic_USGS_version." The parameters of this projection are as given in Table 3.

Table 3. GIS projection parameters.

\begin{tabular}{|l|l|}
\hline Projection & Albers Equal Area \\
\hline Units & meters \\
\hline \multicolumn{2}{|c|}{ Parameters } \\
\hline First standard parallel & $29^{\circ} 30^{\prime} 0.0^{\prime \prime}$ \\
\hline Second standard parallel & $45^{\circ} 30^{\prime} 0.0^{\prime \prime}$ \\
\hline Central meridian & $-96^{\circ} 0^{\prime} 0.00^{\prime \prime}$ \\
\hline Latitude of origin & $23^{\circ} 0^{\prime} 0.00^{\prime \prime}$ \\
\hline False easting $(\mathrm{m})$ & 0.00 \\
\hline False northing $(\mathrm{m})$ & 0.00 \\
\hline Datum: & $\mathrm{NAD} 83$ \\
\hline
\end{tabular}

\section{Interpolation}

Once the SWE had been calculated for all sites using the procedures described above, the SWE was interpolated over the study area (Ochs 2005). The interpolation resulted in an Albers equal-area SWE grid with 1-km grid cells covering a rectangular area encompassing all of the stations that were used in the study (Fig. 9). The SWE in each grid cell was estimated using an inverse distance weighting (IDW) procedure. In this case the square of the distance was chosen as the weighting parameter: 


$$
\overline{S W E}_{\mathrm{m}}=\frac{\sum_{i=1}^{5} \frac{1}{d_{\mathrm{m} \_\mathrm{i}}^{2}}\left(S W E_{\mathrm{i}}\right)}{\sum_{i=1}^{5} \frac{1}{d_{\mathrm{m} \_\mathrm{i}}^{2}}}
$$

where $\overline{S W E}_{\mathrm{m}}$ is the SWE in the $\mathrm{m}^{\text {th }}$ grid cell; $\mathrm{d}_{\mathrm{m}_{-} \mathrm{i}}$ is the distance to the $\mathrm{i}^{\text {th }}$ station where SWE information is available; and $\mathrm{SWE}_{\mathrm{i}}$ is the SWE estimated or observed at the $i^{\text {th }}$ station. . A grid containing the interpolated SWE values in millimeters was created for every day between December 1 and April 30 for the winter of 1979- 1980 to the winter of 2002-2003. After the interpolations, the grids were than clipped to the Lake Superior watershed and the SWE values for each grid cell were rounded to the nearest whole millimeter. The end result was a grid with approximately 128,000 cells with SWE values (Fig. 10). This interpolation process took about one and a half hours of computer processing time for each winter period on a 3.4 GHz PC.

\section{Total SWE}

Once the SWE had been interpolated for each of the grid cells, the water volume over the entire watershed and each sub-basin was calculated. First, the grids were clipped to the Lake Superior basin. The interpolated SWE values for each grid cell were then rounded to the nearest whole millimeter (Fig. 9 and 10). The volume over the entire watershed was found as

$$
V o l_{\text {watershed }}=\sum_{i=1}^{n} \overline{S W E_{\mathrm{i}}} \cdot \text { Area }_{\mathrm{i}}
$$

where $n$ is the number of grid cells in a watershed; Area is the area of the grid cell. The total SWE in cubic meters for each sub-basin was found in this way for every day between 1 December and 30 April for the winter of 1979- 1980 to the winter of 2002- 2003. 


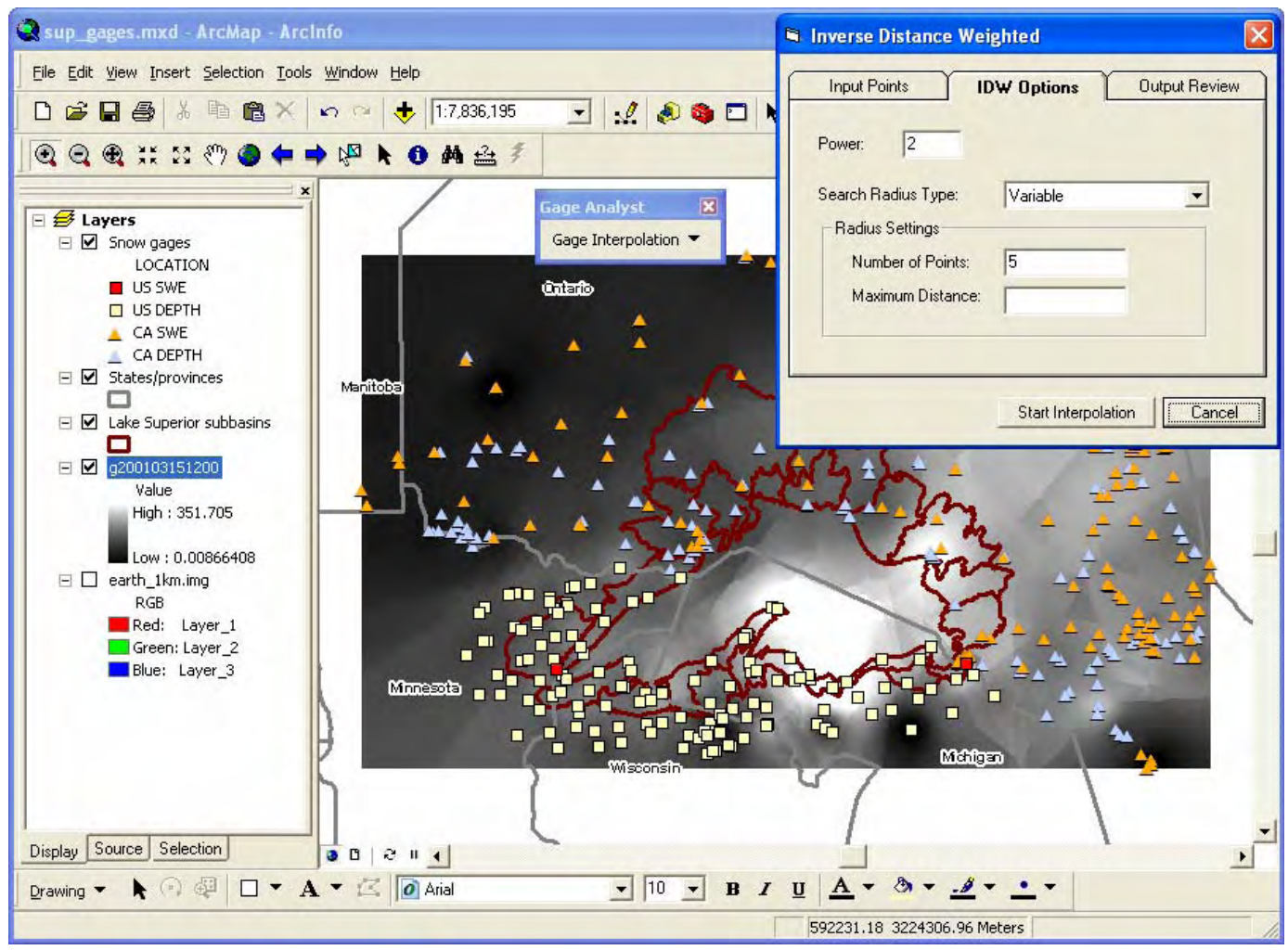

Figure 9. ArcMap and the Gage Analyst extension were used to interpolate the March 15, 2001 SWE grid displayed in a grey-scale color ramp.

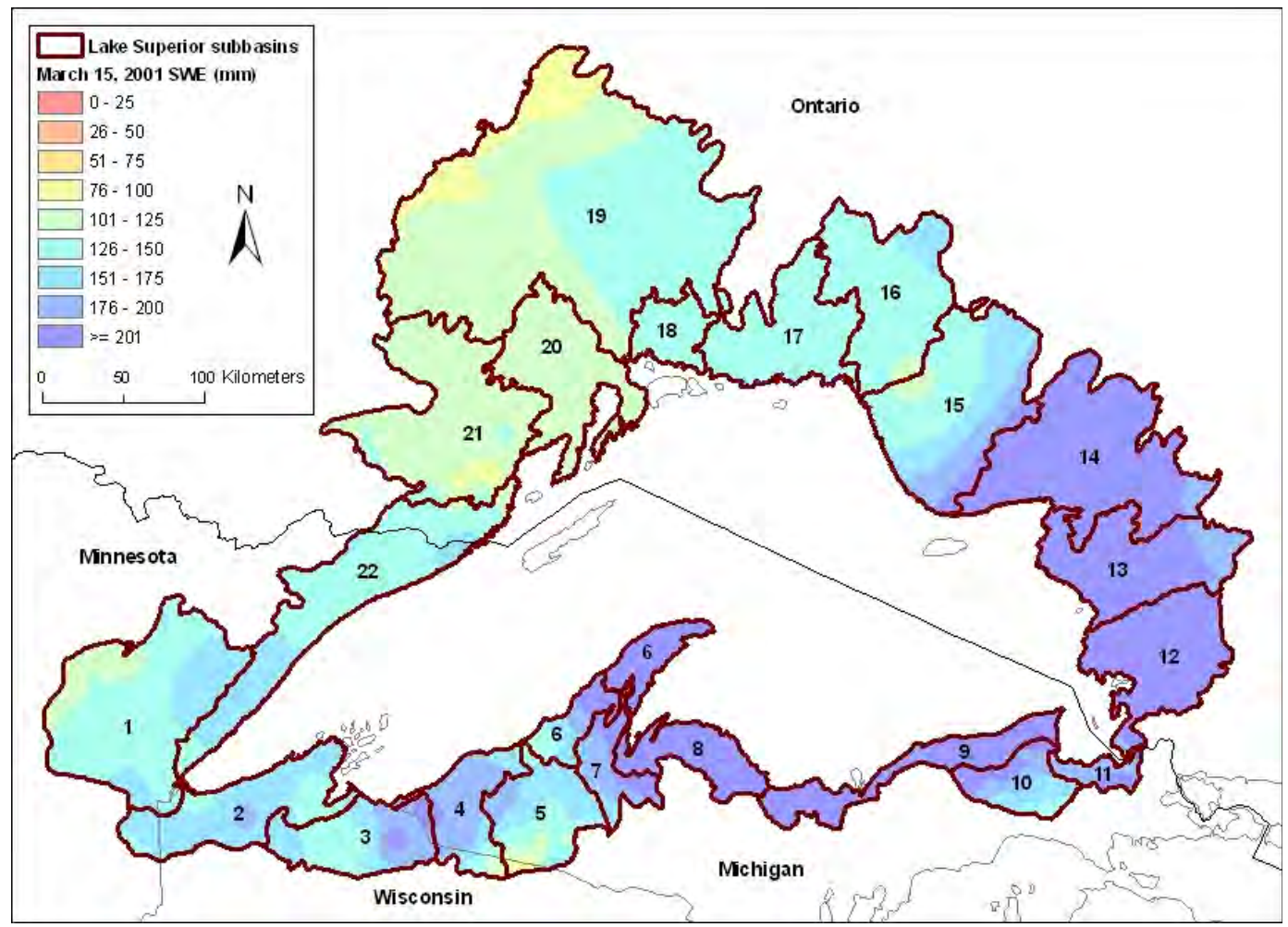

Figure 10. Map showing SWE grid that is clipped to the Lake Superior watershed for 15 March 2001. 


\section{Results}

\section{Total Lake Superior Watershed}

In this section we will concentrate on the results for the total Lake Superior watershed. The calculations described above resulted in an estimate of the total volume of SWE for each of the 22 sub-basins of the Lake Superior watershed for each day between 1 December and 30 April starting in 1979 through 2003. Figure 11 displays the daily time series of the total SWE volume for the Lake Superior watershed for the period of record found by summing the daily totals of the 22 sub-basins. As can be seen, while the SWE volume displays some variation from winter to winter, there is a consistent form to the seasonal variation of SWE. To focus in on this characteristic form, the statistics of the SWE volume were calculated for each day of the winter season between 1 December and 30 April for the entire Lake Superior watershed. For each day of the winter season, Figure 12 displays the average SWE volume, the average plus and minus the standard deviation, and the maximum and minimum SWE volume. This information can be used to describe the characteristics of the SWE volume of the watershed. First, the winter season in can be divided into two distinct periods: a snow accumulation period characterized by increasing SWE, and a snow melt (ablation) period characterized by decreasing SWE; these are separated by the day of the seasonal maximum SWE volume. That day generally occurred in early March, although there was considerable year-to-year variation. The actual day varied between the middle of February and early April; the later in the winter season that the day of the seasonal maximum SWE volume occurred, the larger the value of the SWE maximum tended to be (Fig. 13).

On 1 December, the starting day of the calculations for each winter season, the volume of SWE was greater than zero for all the years of the study, with an average volume of SWE of $2.53 \times 10^{9} \mathrm{~m}^{3}$. This SWE was probably accumulated in the preceding November, indicating a consistent accumulation prior to 1 December. On 30 April, the final day of the calculations for each winter season, the volume of SWE was greater than zero for 17 years of the study period and had reached zero for 7 years. The average volume of SWE on 30 April was $1.01 \times 10^{9} \mathrm{~m}^{3}$ for the non-zero years. 


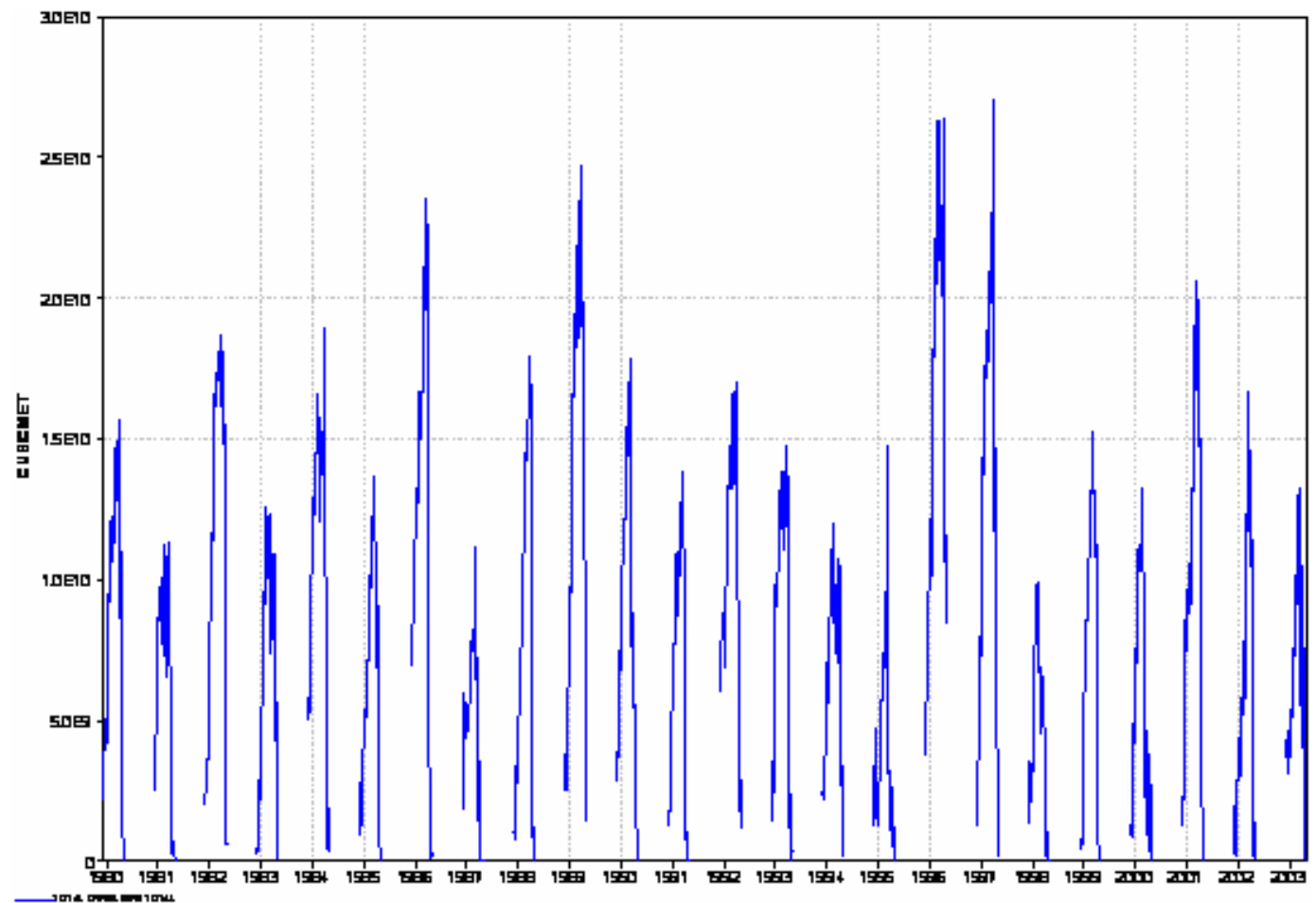

Figure 11. Daily SWE volume for the entire Lake Superior watershed.

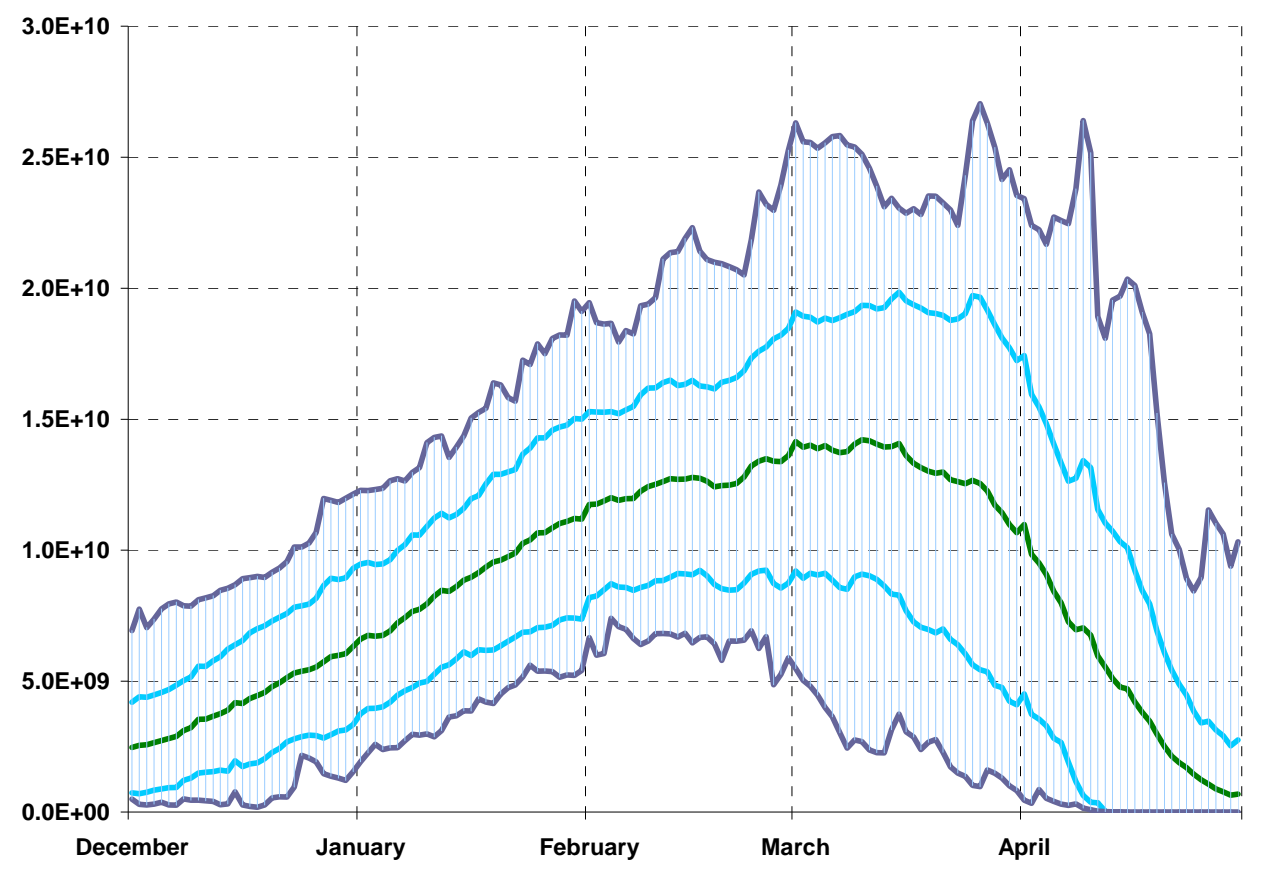

Figure 12. Daily SWE statistics for the entire Lake Superior watershed. Shown are the daily average (green), daily average plus and minus one standard deviation (blue), and the daily historical maximums and minimums. 


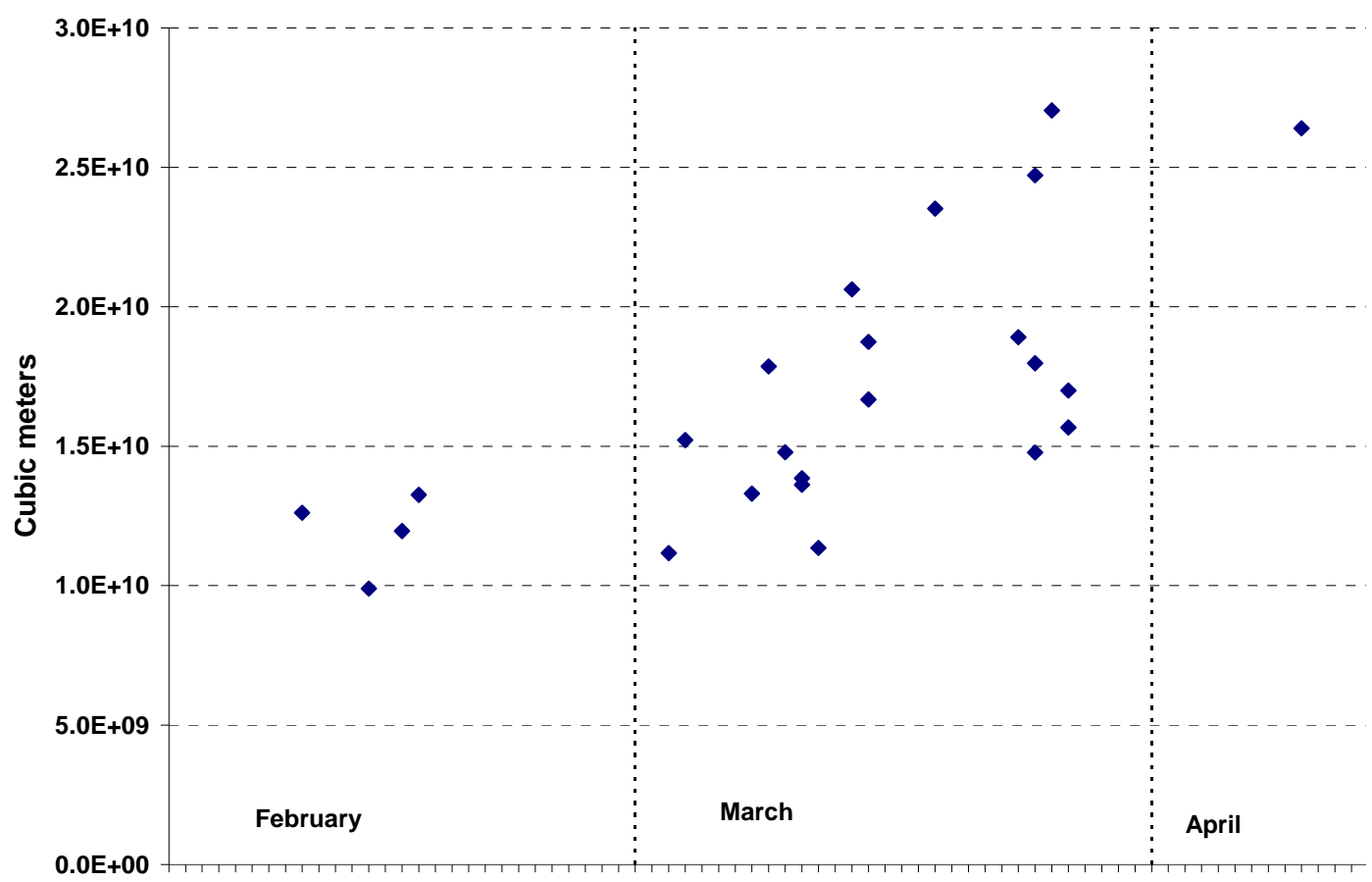

Figure 13. Maximum volume of SWE for the total Lake Superior watershed and the day of year when the maximum occurred.

The snow accumulation and melt periods are times when the overall trend is for either accumulation or melt, but there was not a monotonic increase during the accumulation period or a monotonic decrease during the snow melt period in any year. In fact, episodes of accumulation and melt occurred during each period. These periods can be complex, as snow can accumulate on one portion of the watershed on the same day it is melting in another portion. However, if we take the Lake Superior watershed as a whole, and ignore these sub-watershed spatial variations, we can roughly estimate the total snow accumulation that occurred prior to the day of the maximum SWE volume. The accumulated total SWE volume on each day can be estimated as the seasonal sum of the incremental change in the daily SWE volume, $\mathrm{SWE}_{\mathrm{j}}$, when the change is positive, as

$$
S W E_{\text {acci }}=\sum_{j=2}^{i}\left(S W E_{j}-S W E_{j-1}\right) \text { only when }\left(S W E_{j} \geq S W E_{j-1}\right)
$$

where SWE $E_{\text {acci }}$ is the total accumulated snowfall on day $i$ of the winter season. The calculations are started on 1 December of each year, with the total on that date taken as the accumulation in the previous months. SWE $\mathrm{E}_{\mathrm{acc} i}$ increases monotonically throughout the winter season and reaches a maximum on or before 30 April, the last day for which daily volumes are available. It is clear that $S W E_{a c c i m a x} \geq S W E_{\text {imax }}$, where imax is the day on 
which the seasonal maximum SWE volume occurs. If $\mathrm{SWE}_{j}$ were a monotonically increasing with time, then $\mathrm{SWE}_{\text {acc imax }}$ would be identical to SWEimax. However, in the case of the Lake Superior watershed, the seasonal maximum SWE volume is related to, but always less than, the accumulated total SWE volume that occurred on the day of the seasonal maximum. In fact, $\mathrm{SWE}_{\mathrm{imax}}$ is equal to $68 \%$ of $\mathrm{SWE}_{\mathrm{accimax}}$ on average, indicating that, typically, there was considerable melting during the accumulation periods. Figure 14 plots $S W E_{i m a x}$ against $S W E_{\text {acc imax }}$ for each year and SWE imax against SWEacc 30Apr, the accumulated total seasonal SWE volume on 30 April for year. The 30 April accumulated total can used to represent the accumulated total SWE volume for the entire winter season. The results are presented in terms of SWE depth in millimeters, found by dividing the total volume of SWE in cubic meters by the land area of the Lake Superior watershed.

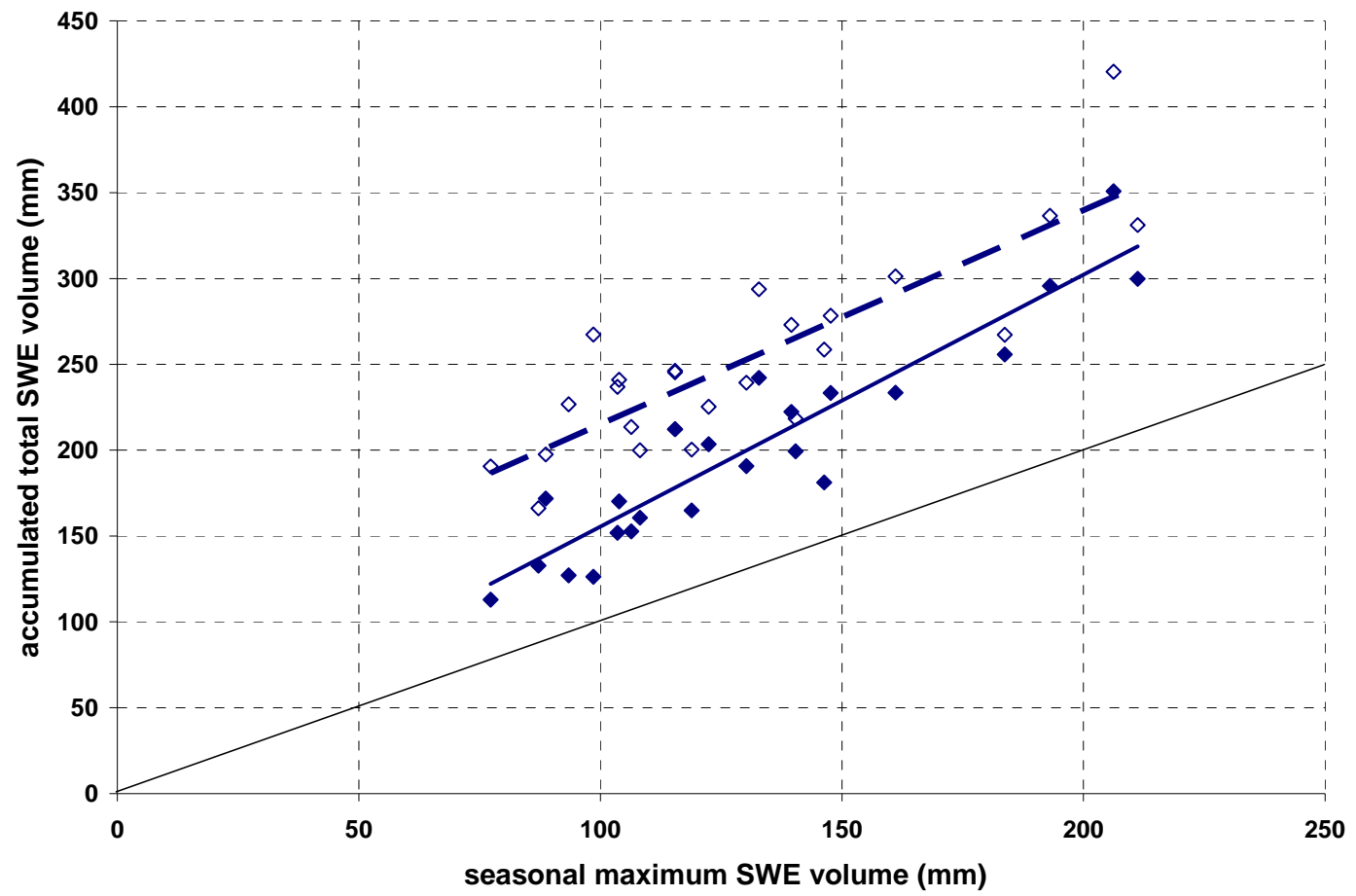

Figure 14. Accumulated SWE volume on the day of the maximum SWE volume (solid diamonds), and accumulated SWE volume on 30 April (open diamonds) plotted against the seasonal maximum SWE volume for each year.

The annual series of the seasonal maximum SWE is shown in Figure 15, along with the total snow accumulation that occurred up to and including the day of the maximum SWE volume, and the accumulated total seasonal SWE volume on 30 April each year. It can be seen that there is no overall trend in these values. The largest SWE volumes occurred in 1996 and 1997. 


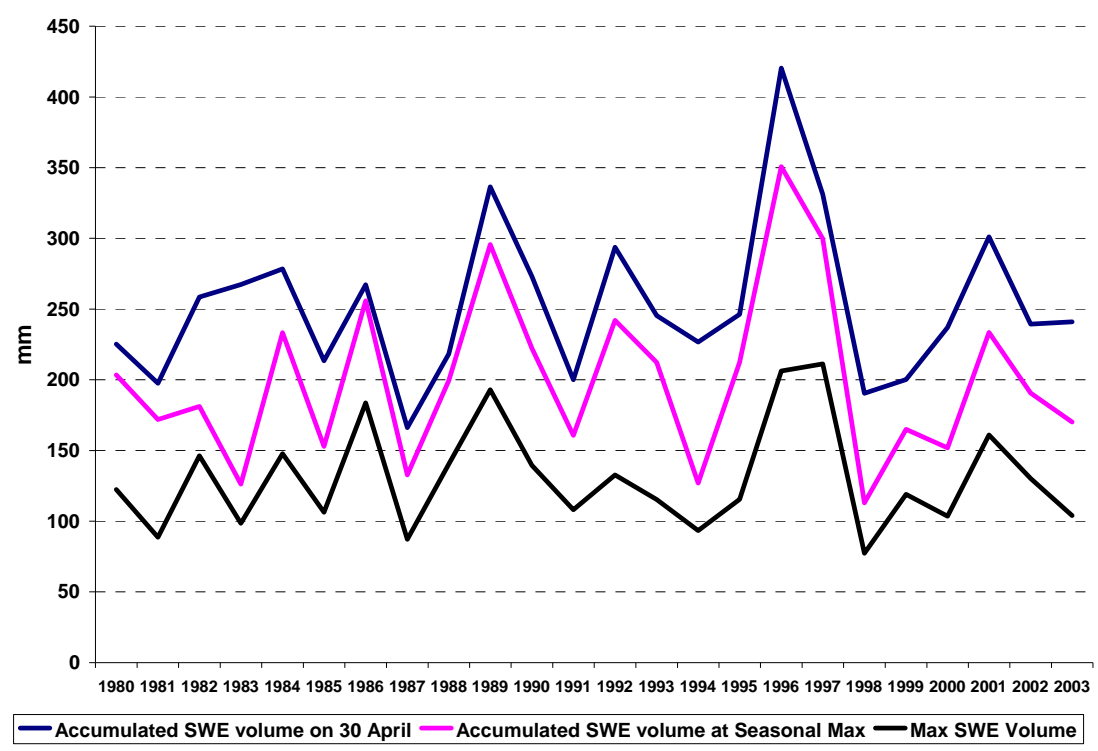

Figure 15. Maximum SWE volume, accumulated SWE volume on the day of the maximum SWE volume, and accumulated SWE volume on 30 April.

\section{Lake Superior Sub-basins}

Figure 16 displays the daily time series of SWE volume for the 22 Lake Superior sub-basins. The annual maximum SWE volume for each sub-basin for each year of the study is listed in Table $4 a$ and $b$. The average annual maximum SWE volume and the average annual SWE depth for each subbasin are listed in Table 1.

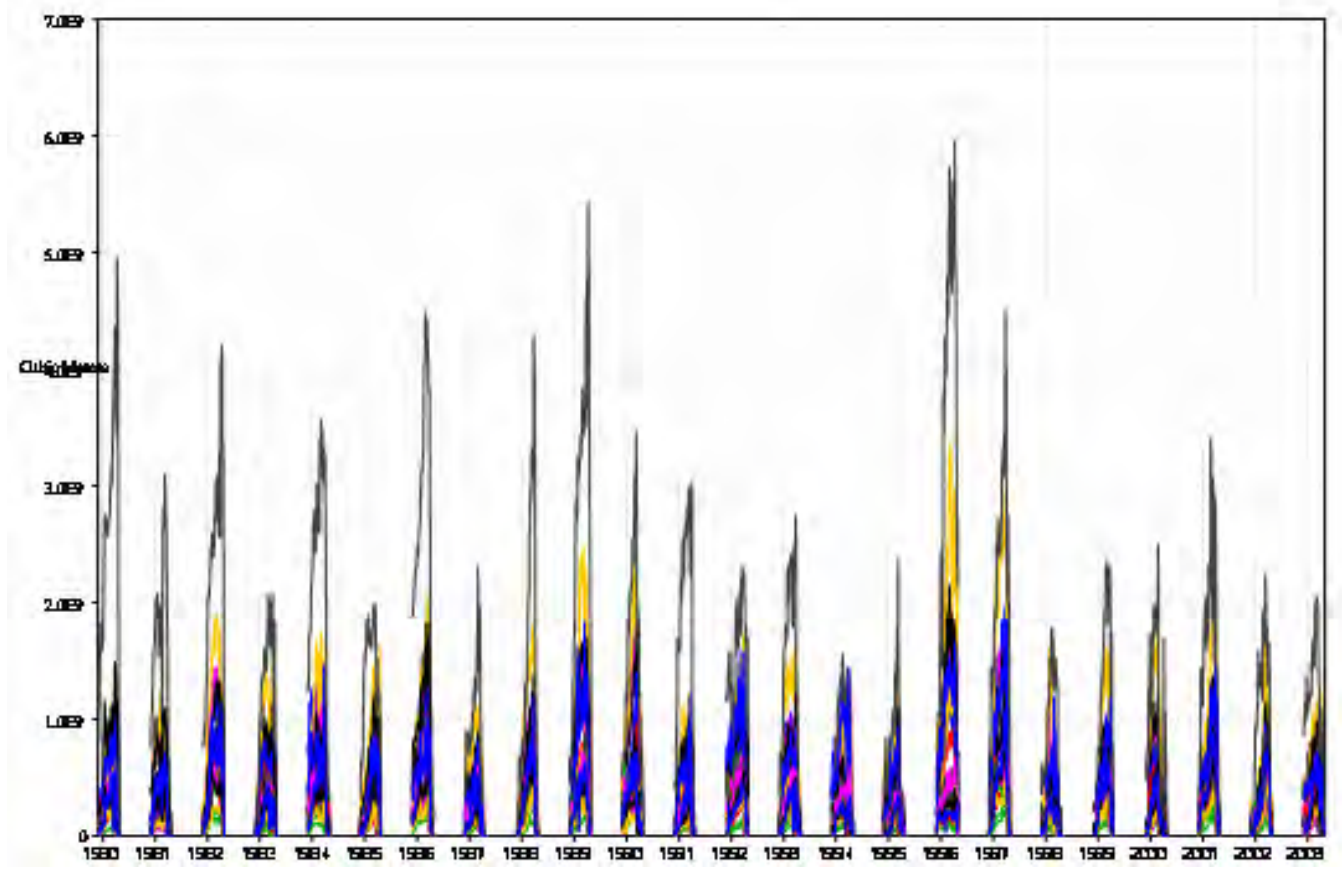

Figure 16. Daily SWE volume for the Lake Superior sub-basins. 
Table 4. Total Lake Superior and sub-basins annual maximum. SWE $\times 10^{8}\left(\mathrm{~m}^{3}\right)$ (maximum year in POR is in bold).

a. Sub-basins 1-11

\begin{tabular}{|c|c|c|c|c|c|c|c|c|c|c|c|c|}
\hline \multirow{2}{*}{ Year } & \multicolumn{12}{|l|}{ Basins } \\
\hline & Total & 1 & 2 & 3 & 4 & 5 & 6 & 7 & 8 & 9 & 10 & 11 \\
\hline 1980 & 56.73 & .02 & 3.45 & .43 & 4.02 & 4.49 & 5.41 & 2.24 & 4.25 & 5.69 & 3.63 & 1.19 \\
\hline 1981 & 13.53 & 3.78 & 1.79 & 2.40 & 3.98 & 4.43 & 3.74 & 2.06 & 4.22 & 7.24 & 4.13 & 1.59 \\
\hline 1982 & 37.33 & 3.06 & 5.83 & 4.91 & 4.85 & 6.79 & 5.97 & 3.29 & 6.28 & .33 & 5.74 & 1.83 \\
\hline 1983 & 26.14 & 2.55 & 6.31 & .25 & 5.15 & 5.87 & 5.29 & 3.79 & 4.70 & .58 & 1.93 & 0.85 \\
\hline 1984 & 189.08 & 13.07 & 6.41 & 5.87 & 5.95 & 7.57 & 9.76 & 4.37 & 11.23 & 14.61 & 4.33 & 1.19 \\
\hline 1985 & 36.17 & 8.59 & 3.86 & 4.44 & 5.46 & 6.61 & 6.05 & 4.39 & 6.00 & 8.39 & 4.92 & 1.76 \\
\hline 1986 & 35.16 & 2.08 & 5.75 & 5.27 & 6.06 & 7.54 & 6.35 & 4.28 & 8.24 & 9.29 & 5.15 & 2.01 \\
\hline 1987 & 111.61 & 6.32 & 2.78 & 3.18 & 2.94 & 3.51 & 2.82 & 1.84 & 2.55 & 3.44 & 2.39 & 0.87 \\
\hline 1988 & 9.76 & 01 & 5.60 & 30 & 5.68 & 46 & 6.91 & 00 & 69 & .98 & 5.35 & 1.42 \\
\hline 1989 & 247.15 & 2.24 & 9.61 & 8.20 & 7.63 & 8.87 & 7.26 & 4.42 & 5.85 & 6.44 & 4.86 & 1.79 \\
\hline 1990 & 178.62 & 6.09 & 3.39 & 3.85 & 4.96 & 5.28 & 4.62 & 2.84 & 3.76 & 5.21 & 3.97 & 1.74 \\
\hline 1991 & 8.49 & 55 & 5.71 & 58 & 5.31 & .44 & 4.22 & 2.91 & 3.48 & .2 & 2.58 & 0.71 \\
\hline 1992 & 169.99 & 5.87 & 6.79 & 5.53 & 7.29 & 7.40 & 6.04 & 4.34 & 5.67 & 4.82 & 3.57 & 1.49 \\
\hline 1993 & 147.76 & 10.55 & 4.35 & 3.87 & 4.11 & 5.22 & 5.89 & 3.39 & 4.98 & 4.79 & 4.04 & 1.03 \\
\hline 1994 & 9.59 & 3.43 & 5.01 & 22 & 5.09 & 73 & 6.03 & .85 & 2.67 & 3.51 & .91 & 0.85 \\
\hline 1995 & 147.79 & 9.65 & 4.57 & 3.55 & 4.11 & 4.67 & 3.85 & 2.52 & 3.48 & 3.49 & 2.14 & 1.68 \\
\hline 1996 & 3.97 & 5.29 & 6.90 & .78 & 4.78 & 5.81 & 6.48 & 4.31 & 4.11 & 2.7 & 1.74 & 1.22 \\
\hline 1997 & 270.44 & 19.58 & 9.18 & 7.51 & 6.30 & 8.16 & 7.59 & 5.19 & 8.33 & 10.81 & 6.38 & 2.23 \\
\hline 1998 & 98.92 & 7.60 & 3.03 & 2.86 & 3.03 & 3.90 & 3.14 & 1.97 & 3.59 & 3.51 & 1.97 & 0.92 \\
\hline 1999 & 2.22 & 80 & 4.33 & 4.21 & 5.61 & 6.90 & 5.66 & 3.64 & 5.86 & 0.50 & 2.92 & 1.32 \\
\hline 2000 & 1 & 02 & 3.90 & 21 & 3.96 & 66 & 3.69 & 58 & 4.09 & .9 & 2.93 & 1.19 \\
\hline 2001 & 206.21 & 14.30 & 7.95 & 6.52 & 7.51 & 6.92 & 7.61 & 4.71 & 7.03 & 8.94 & 4.60 & 1.70 \\
\hline 2002 & 166.71 & 11.62 & 7.53 & 7.87 & 7.37 & 8.92 & 7.14 & 5.09 & 7.78 & 7.45 & 3.82 & 1.50 \\
\hline 2003 & 133.02 & 5.87 & 3.57 & 3.91 & 4.60 & 5.63 & 5.72 & 3.18 & 5.03 & 7.1 & 4.58 & 1.0 \\
\hline
\end{tabular}


b. Sub-basins 12-22.

\begin{tabular}{|c|c|c|c|c|c|c|c|c|c|c|c|}
\hline \multirow{2}{*}{ Year } & \multicolumn{11}{|l|}{ Basins } \\
\hline & 12 & 13 & 14 & 15 & 16 & 17 & 18 & 19 & 20 & 21 & 22 \\
\hline 1980 & 9.91 & 52 & 11.56 & 0.19 & 0.23 & 8.05 & 3.78 & 49.51 & 7.48 & 14.93 & 8.76 \\
\hline 1981 & 12.57 & .04 & 12.58 & 7.44 & 4.15 & 3.06 & 1.34 & 30.97 & 3.58 & 10.98 & 5.47 \\
\hline 1982 & 14.30 & 14.46 & 19.18 & 13.38 & 9.66 & 10.37 & 2.97 & 42.17 & 5.73 & 11.16 & 1.37 \\
\hline 1983 & 8.83 & 8.45 & 14.65 & .18 & 8.98 & 6.70 & 1.70 & 2.76 & 3.90 & 8.91 & .97 \\
\hline 1984 & 13.90 & 12.49 & 17.47 & 1.30 & 61 & 7.52 & 2.45 & 5.77 & .67 & 3.20 & .97 \\
\hline 1985 & 10.18 & 8.78 & 16.29 & 12.37 & 7.51 & 5.22 & 1.53 & 24.72 & 4.04 & 7.55 & 8.61 \\
\hline 1986 & 18.76 & 16 & 20.34 & 3.27 & 2.82 & .61 & 3.54 & 4.84 & 10.35 & 16.10 & 0.39 \\
\hline 1987 & 6.46 & 6.88 & 11.33 & 8.98 & 8.13 & 3.37 & 1.39 & 23.09 & 3.43 & 4.96 & 5.15 \\
\hline 1988 & 10.38 & 12.20 & 18.02 & 13.77 & 11.96 & 8.69 & 2.80 & 42.90 & 4.45 & 5.77 & 7.69 \\
\hline 1989 & .40 & 16.51 & 24.70 & 6.99 & 2.66 & 9.69 & 3.78 & 54.29 & 9.47 & 16.12 & 16.84 \\
\hline 1990 & 16.94 & 16.63 & 23.22 & 17.94 & 14.06 & 9.57 & 3.42 & 34.67 & 6.53 & 9.04 & 7.12 \\
\hline 1991 & 9.36 & 9.27 & 12.24 & 9.99 & 7.59 & 5.74 & 2.69 & 30.36 & 6.58 & 8.58 & 12.06 \\
\hline 1992 & 11.40 & 11.78 & 1 & 9 & 97 & 6.82 & 1.08 & 4 & 3.99 & 43 & 5.82 \\
\hline 1993 & 8.73 & 10.32 & 16.76 & 12.46 & 9.11 & 7.73 & 2.76 & 27.46 & 5.75 & 9.69 & 8.85 \\
\hline 1994 & .51 & 12.94 & 13.68 & 6.33 & 97 & 3.55 & 1.40 & 5.58 & 3.68 & 6.89 & 14.28 \\
\hline 1995 & 9.15 & 11.63 & 16 & 7 & 82 & 6.20 & 1.55 & 23.73 & 4.75 & 10.77 & 9.3 \\
\hline 1996 & 16.63 & 19.74 & 33.54 & 19.51 & 12.28 & 9.85 & 4.79 & 59.68 & 13.16 & 21.46 & 16.68 \\
\hline 1997 & 13.96 & 17.57 & 29.47 & 4 & 6 & 8 & 3.51 & 45.05 & 9.14 & 4.15 & 18.59 \\
\hline 1998 & 8.23 & 10.82 & 16.04 & 5.05 & 3.13 & 2.63 & 1.17 & 17.86 & 3.49 & 6.13 & 11.98 \\
\hline 1999 & 10.20 & 10.41 & 16.03 & 9.50 & 6.41 & 5.40 & 1.81 & 23.57 & 5.49 & 10.14 & 11.74 \\
\hline 2000 & 9.42 & 11.44 & 21.15 & 2.12 & 7 & 6.55 & 2.17 & 25.03 & 4.64 & 6.49 & 5.4 \\
\hline 2001 & 11.20 & 13.57 & 23.95 & 13.70 & 9.76 & 8.13 & 2.91 & 4.02 & 7.46 & 12.38 & 14.54 \\
\hline 2002 & 9.50 & 10.36 & 16.45 & 11.46 & 6.55 & 3.98 & 1.57 & 22.47 & 3.84 & 5.93 & 9.54 \\
\hline 2003 & 10.89 & 8.52 & 12.37 & 9.91 & 6.97 & 4.24 & 1.35 & 20.46 & 3.01 & 5.07 & 5.95 \\
\hline
\end{tabular}

Figure 17 displays the annual maximum SWE volume converted to a depth in millimeters, and shows that the range of annual maximums depths can vary from year to year. It is interesting to note that the years of maximum SWE for the Lake Superior basin, 1996 and 1997, do not necessarily have the maximum SWE depths for the sub-basins. The maximum years are 1996 and 1997 because nearly all the sub-basins had large SWE values but only twelve sub-basins had record high values in those two years. In abso- 
lute terms, 1984 had the largest sub-basin SWE depths on record, but in that year only three sub-basins had record values and many had relatively modest SWE depths.

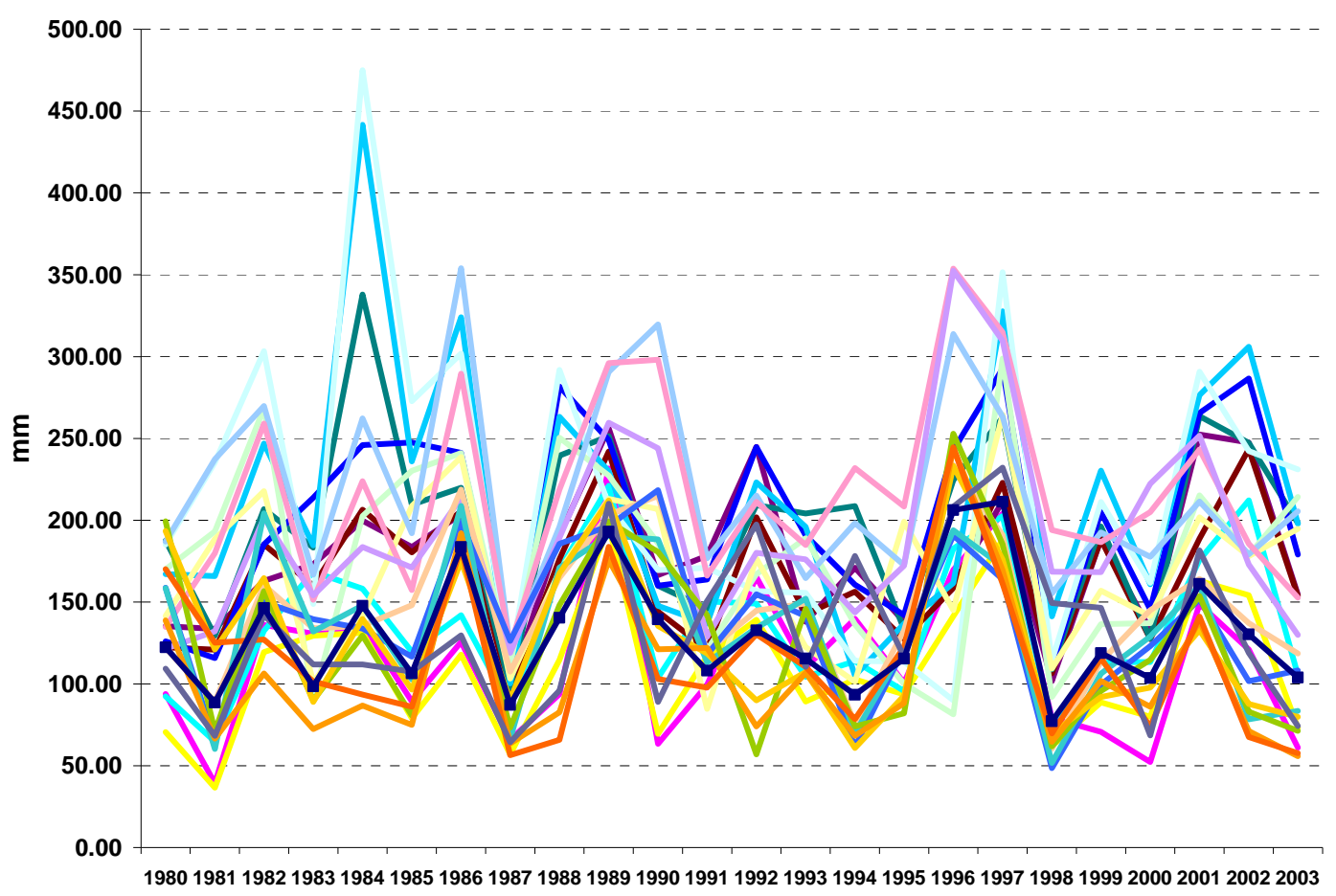

Figure 17. Maximum SWE volume in $\mathrm{mm}$ for all 22 Lake Superior sub-basins. The line with rectangular markers is for the entire Lake Superior watershed.

The average SWE depth for each sub-basin is displayed in Figures 18 and 19, along with the standard deviation of the SWE depths. Sub-basins 6, 7, 8, and 9 along the south coast of Lake Superior in Michigan's Upper Peninsula have the largest average SWE depths along with sub-basins 12 and 13, which are at the eastern end of Lake Superior in Ontario, Canada, with sub-basin 12 abutting the United States. Lake effect snows probably account for the larger average SWE depths in all cases. The average day of year when the maximum SWE volume occurs is generally in early to midMarch for all the sub-basins, with the most northern basins-16, 17, and 18-occurring later. There is also a tendency for sub-basins located in the western end of the watershed to reach their maximums earlier in the winter. 


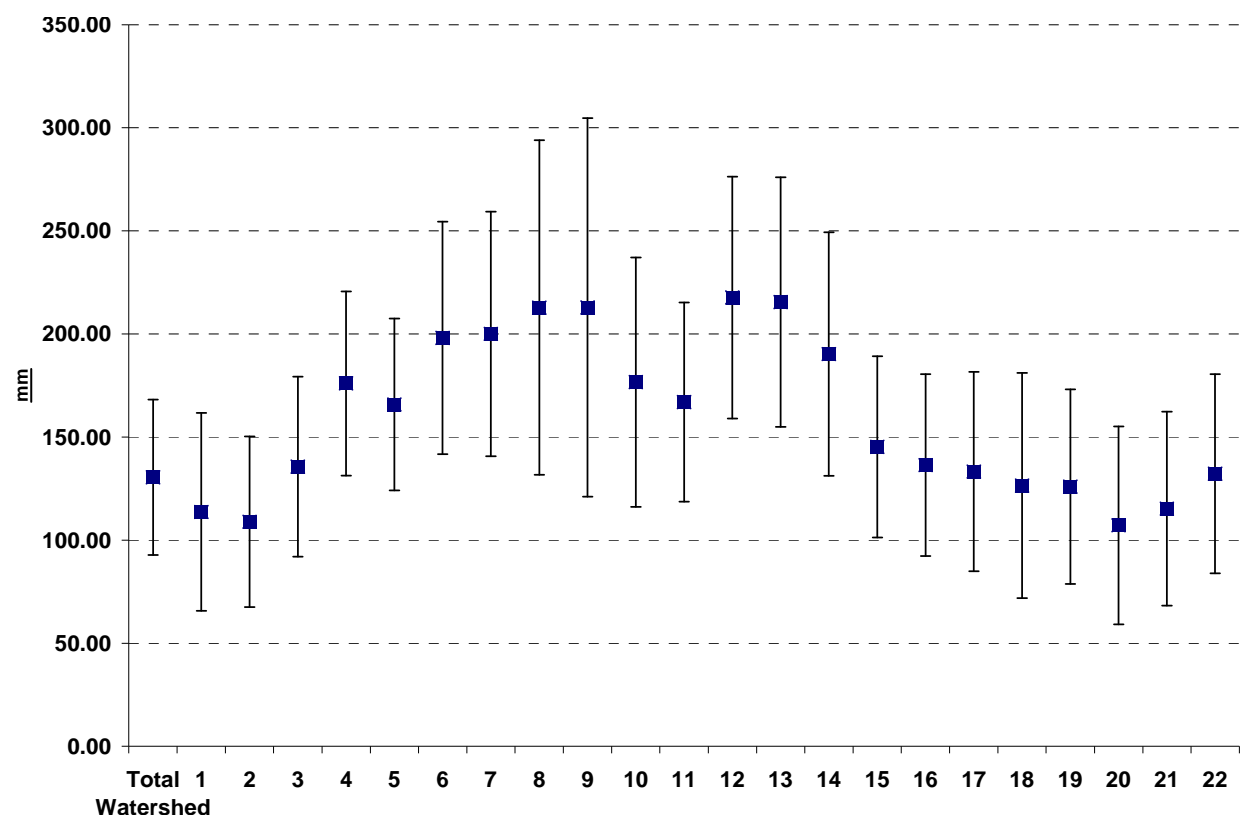

Figure 18. Average and standard deviation of the maximum volume of SWE for the total Lake Superior watershed and the 22 sub-basins.

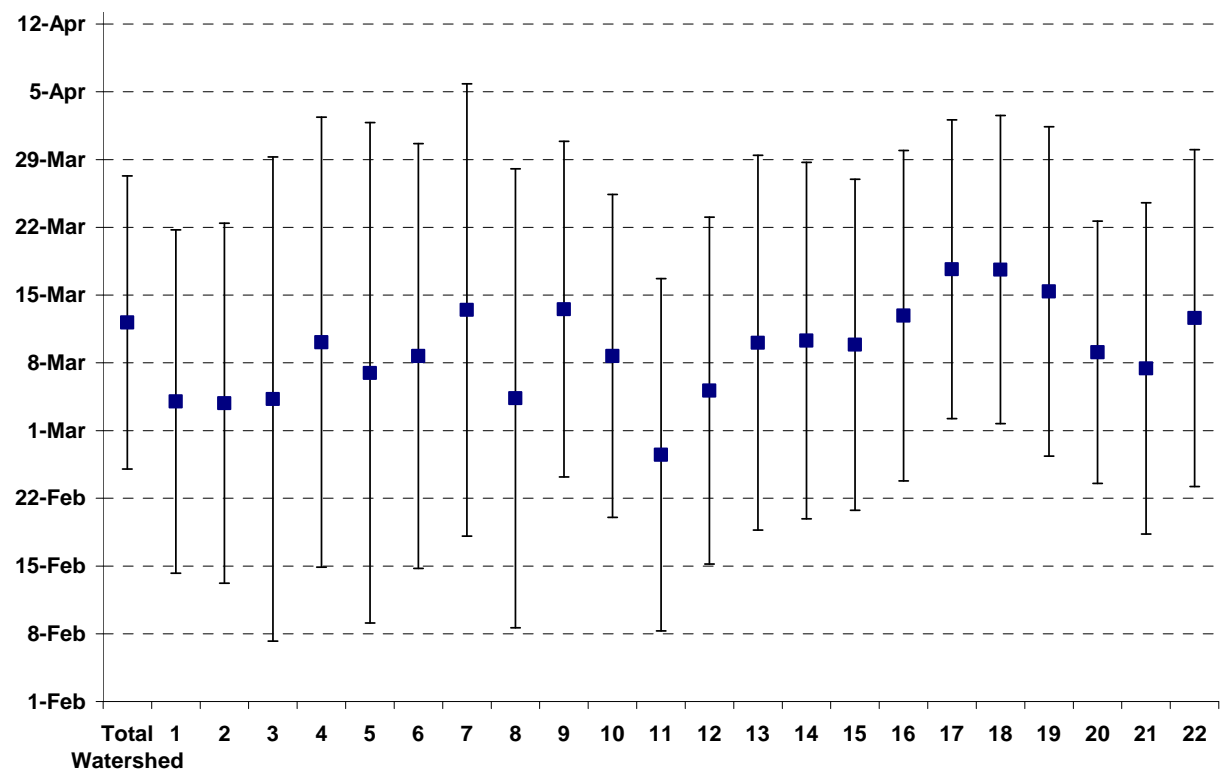

Figure 19. Average day of year and standard deviation of the maximum volume of SWE for the total Lake Superior watershed and the 22 sub-basins.

\section{Mean SWE Maps}

To estimate the areal distribution of SWE throughout the winter, a grid representing the mean SWE for the 1st and 15th of each winter month was calculated. First all the daily grids that represented 1 December of each year were collected from 1979-2002 and then were averaged on a cell by cell basis. A map was then created to present the final mean results. This 
process was then repeated for the 15th of December, 1st of J anuary (using the years 1980-2003), etc, through the 15th of April. The end result was a series of maps displaying the mean SWE for the 1st and 15th of each month. (Fig. 20).

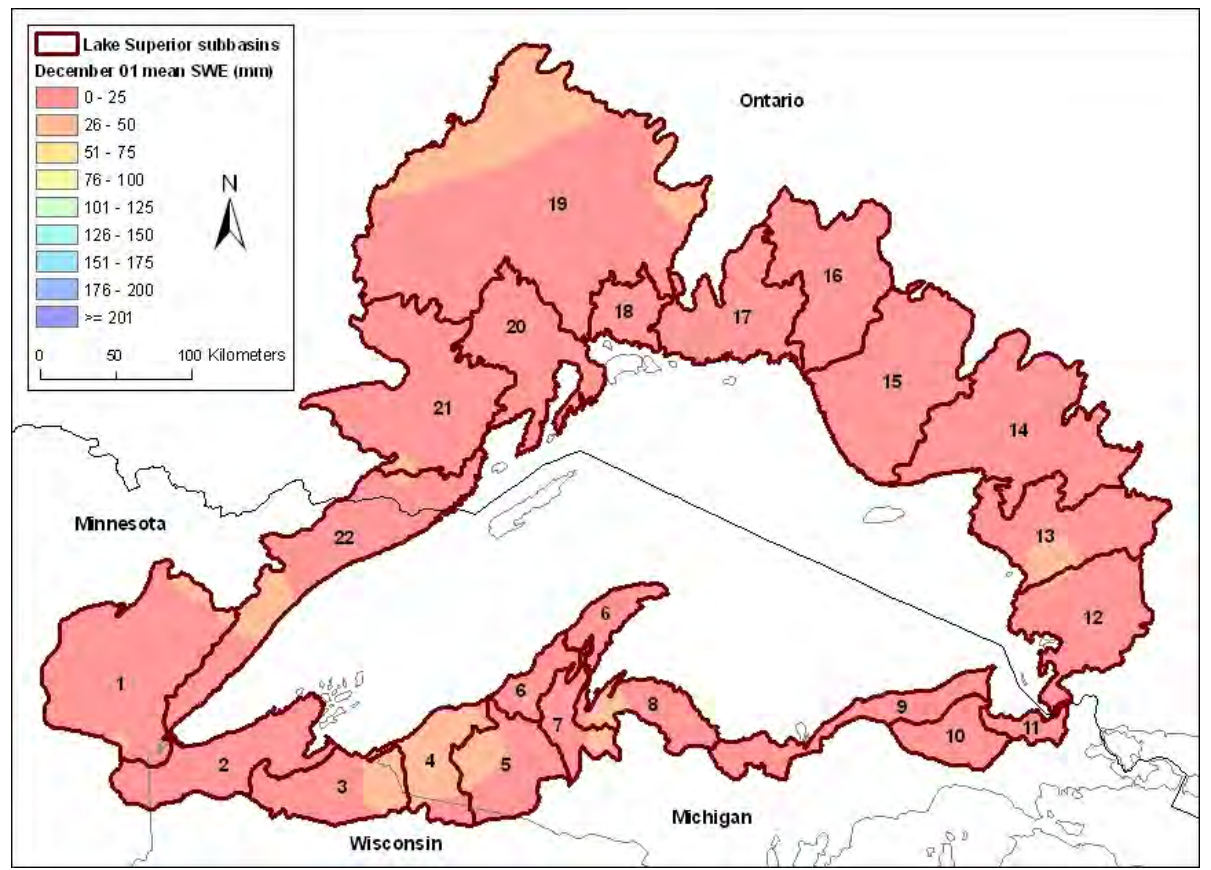

a. 1 December.

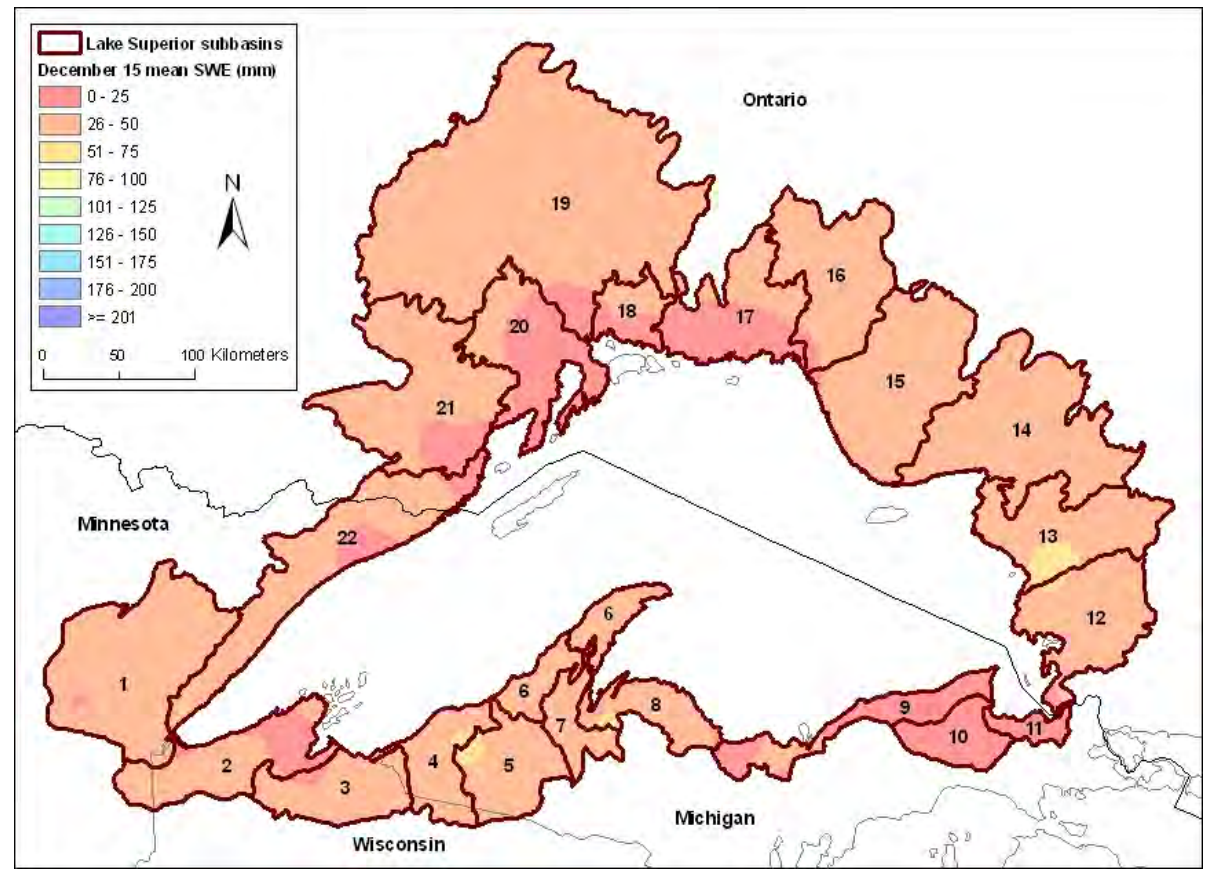

b. 15 December.

Figure 20. Mean SWE Distribution for the entire Lake Superior watershed for the $1^{\text {st }}$ and $15^{\text {th }}$ of each month throughout the winter season. 


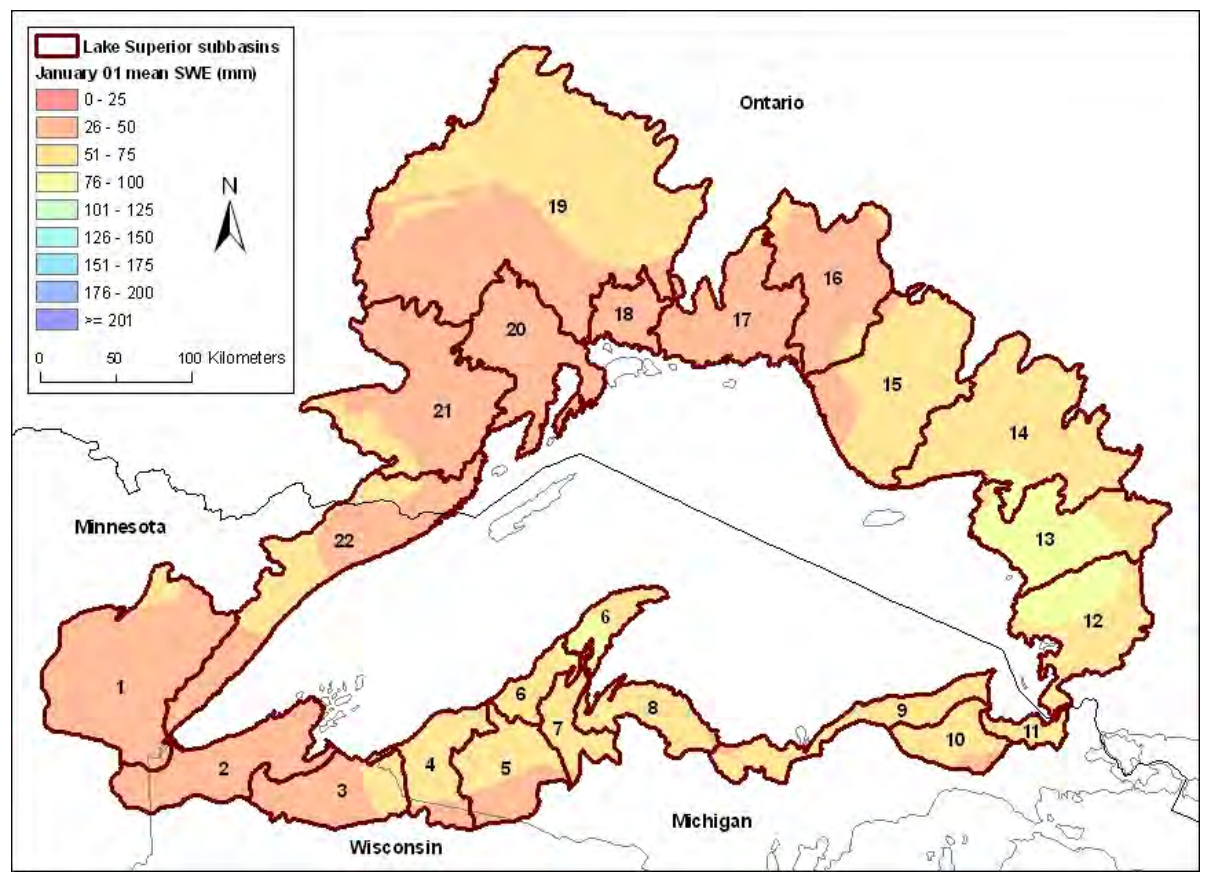

c. 1 January.

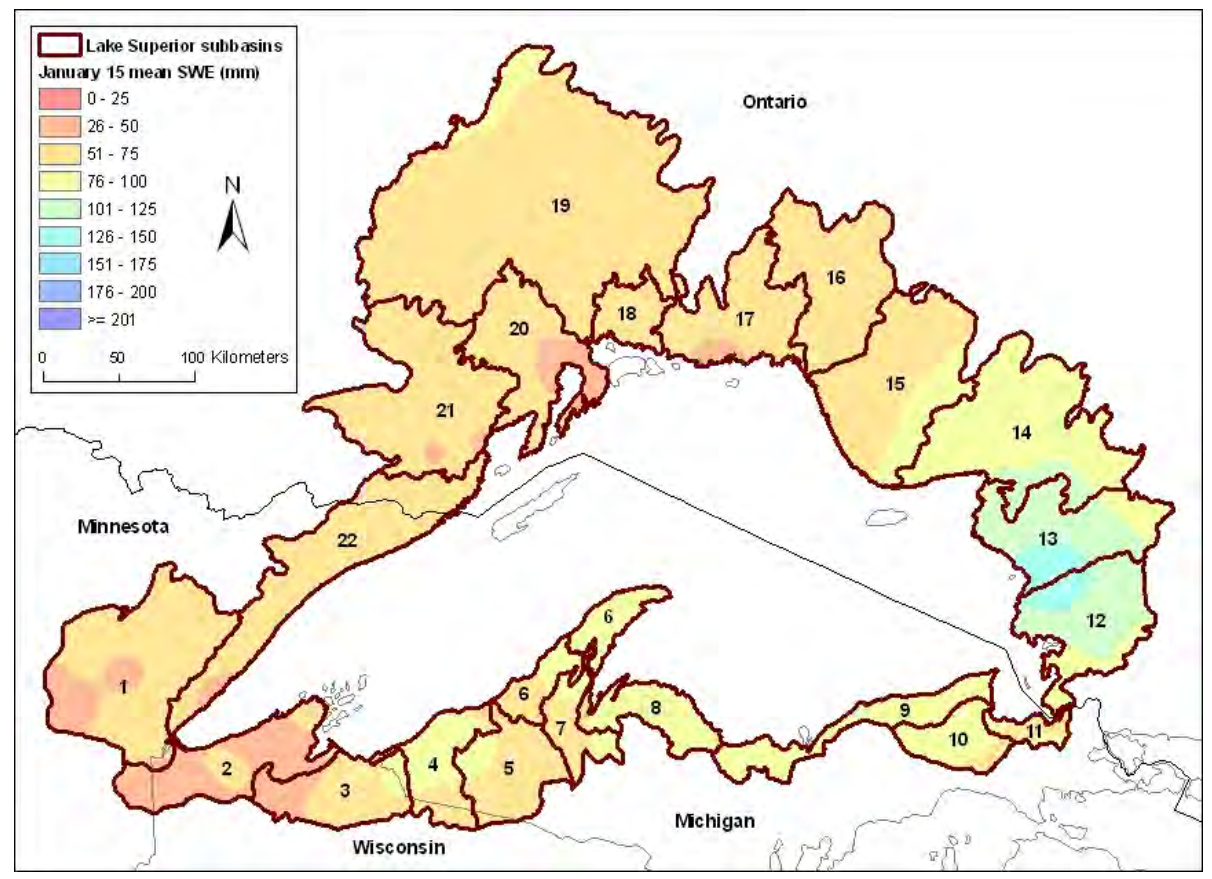

d. 15 January.

Figure 20 (cont'd). Mean SWE Distribution for the entire Lake Superior watershed for the $1^{\text {st }}$ and $15^{\text {th }}$ of each month throughout the winter season. 


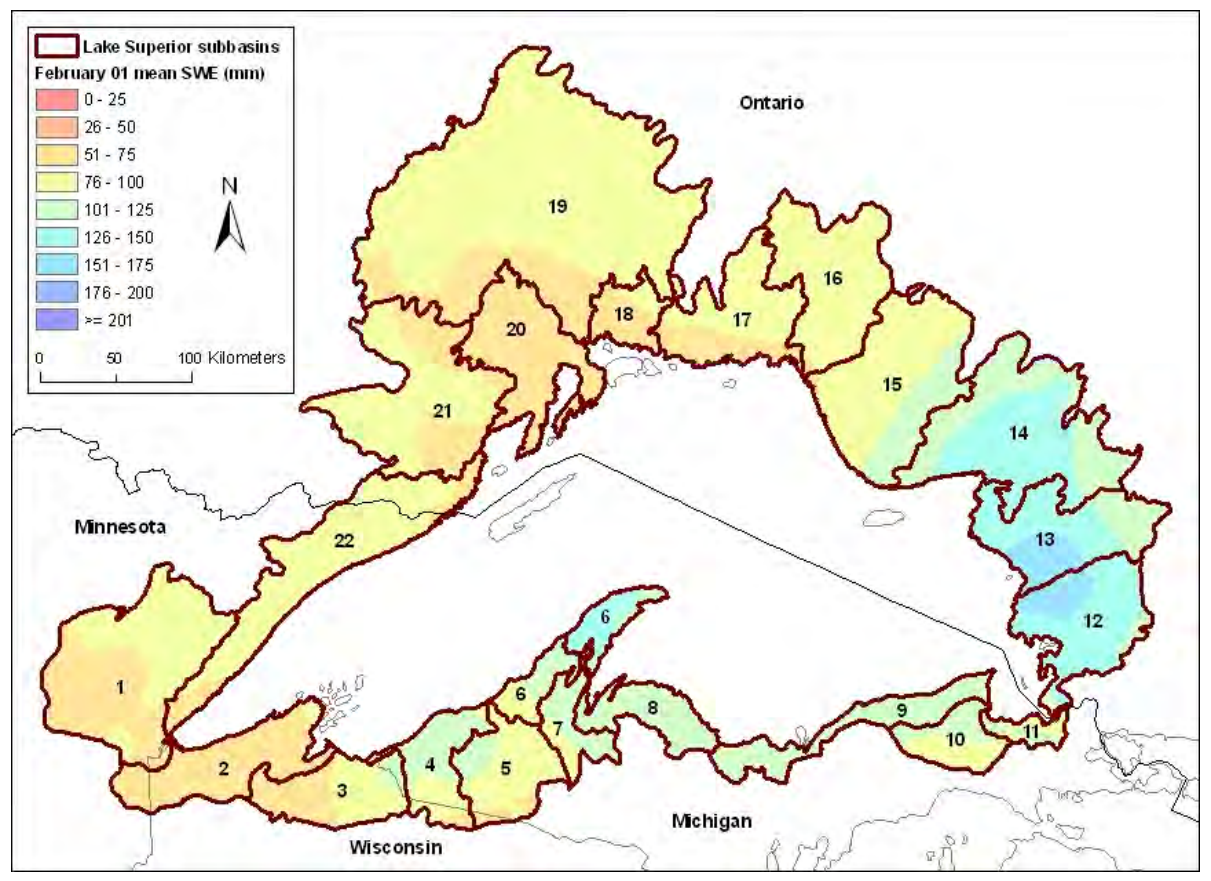

e. 1 February.

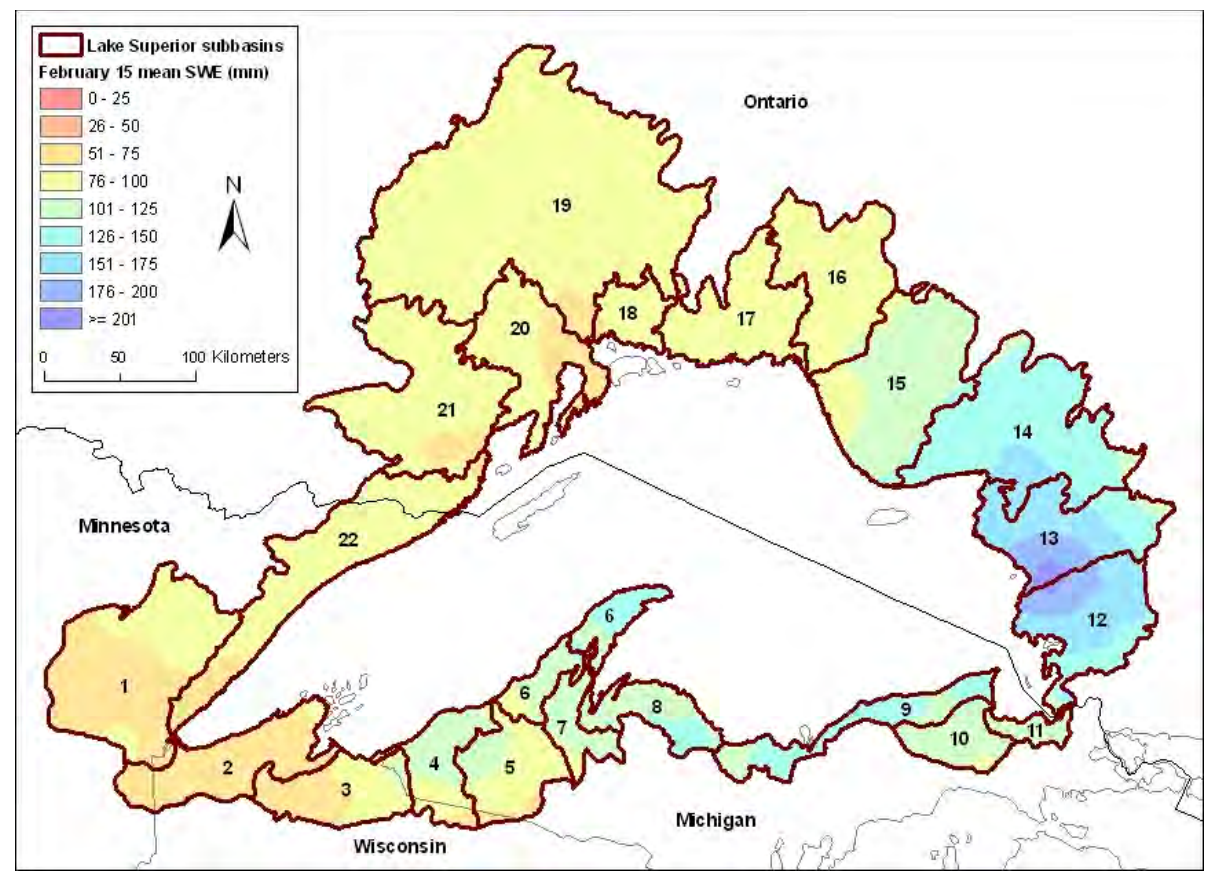

f. 15 February.

Figure 20 (cont'd). Mean SWE Distribution for the entire Lake Superior watershed for the $1^{\text {st }}$ and $15^{\text {th }}$ of each month throughout the winter season. 


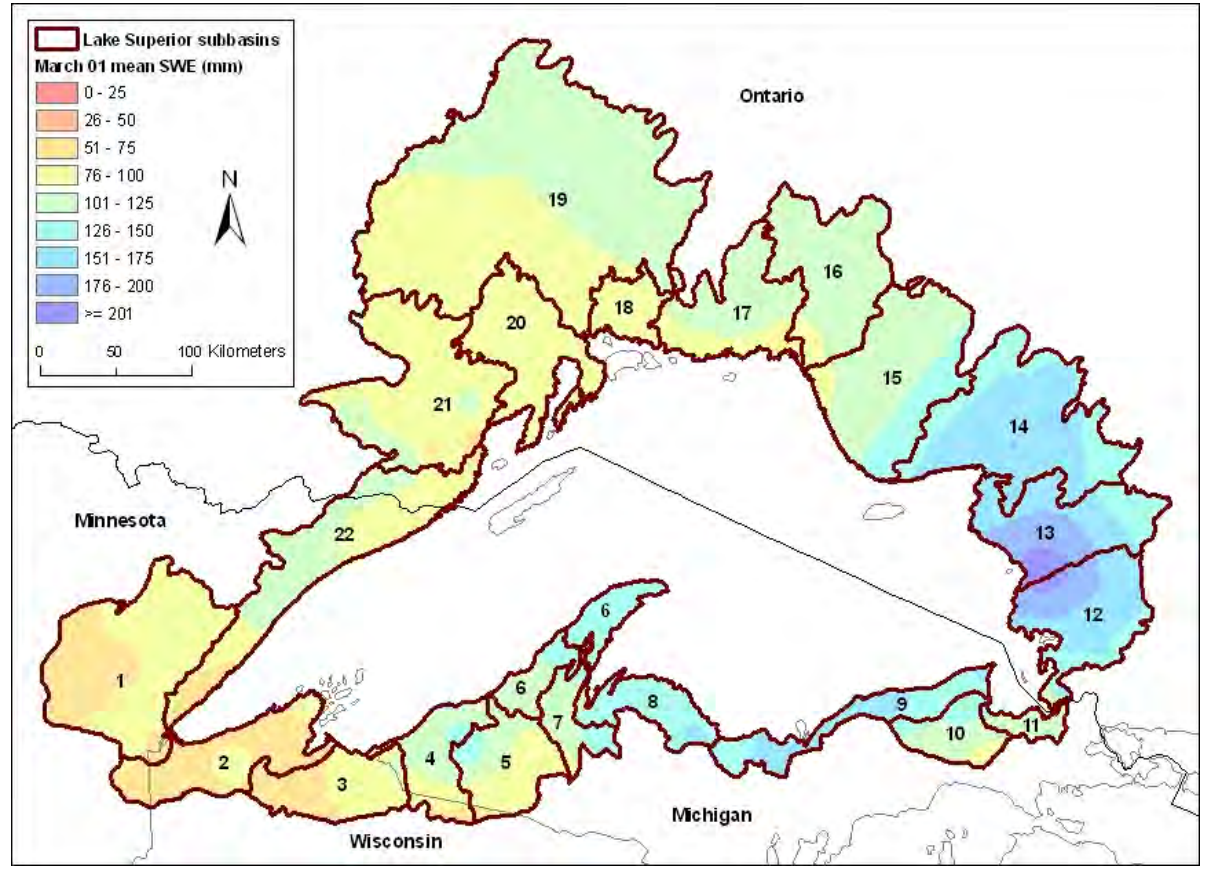

g. 1 March.

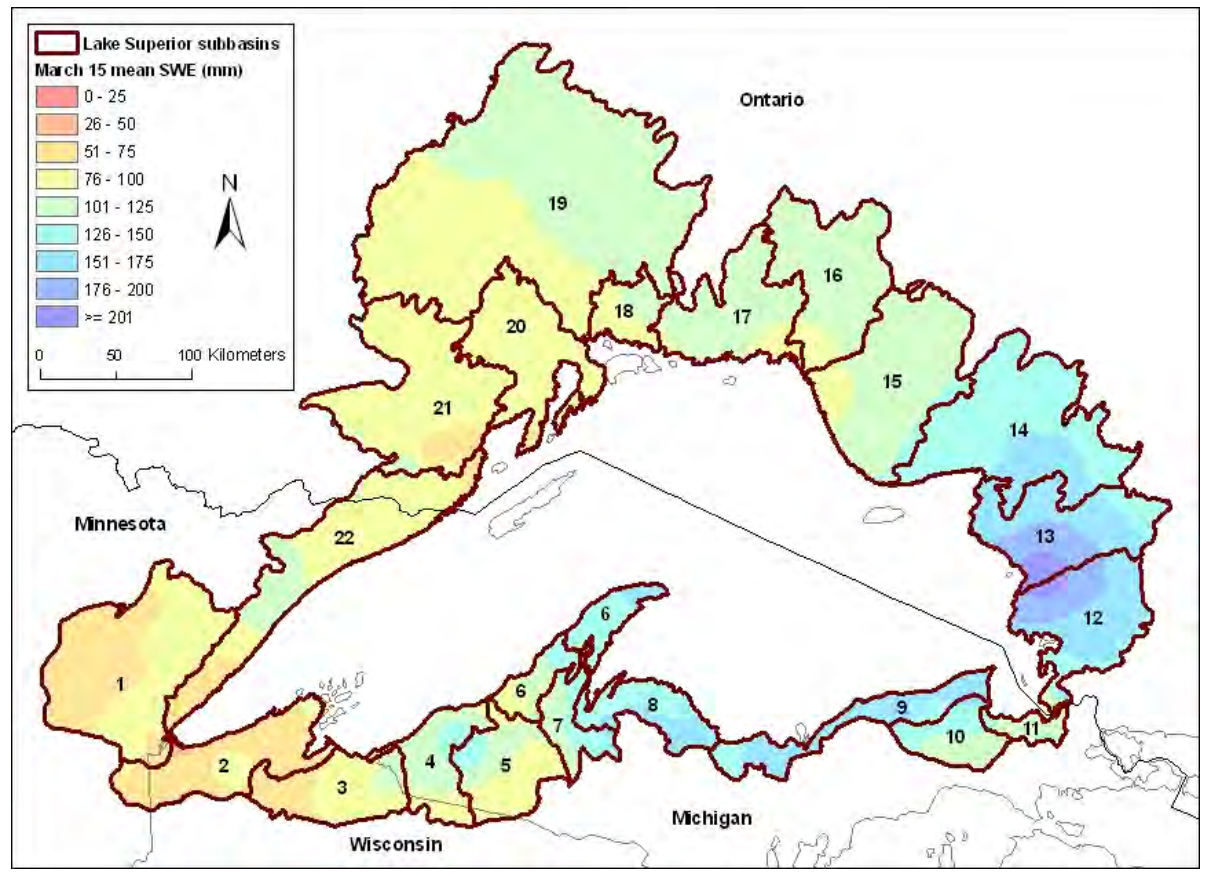

i. 15 March.

Figure 20 (cont'd). Mean SWE Distribution for the entire Lake Superior watershed for the $1^{\text {st }}$ and $15^{\text {th }}$ of each month throughout the winter season. 


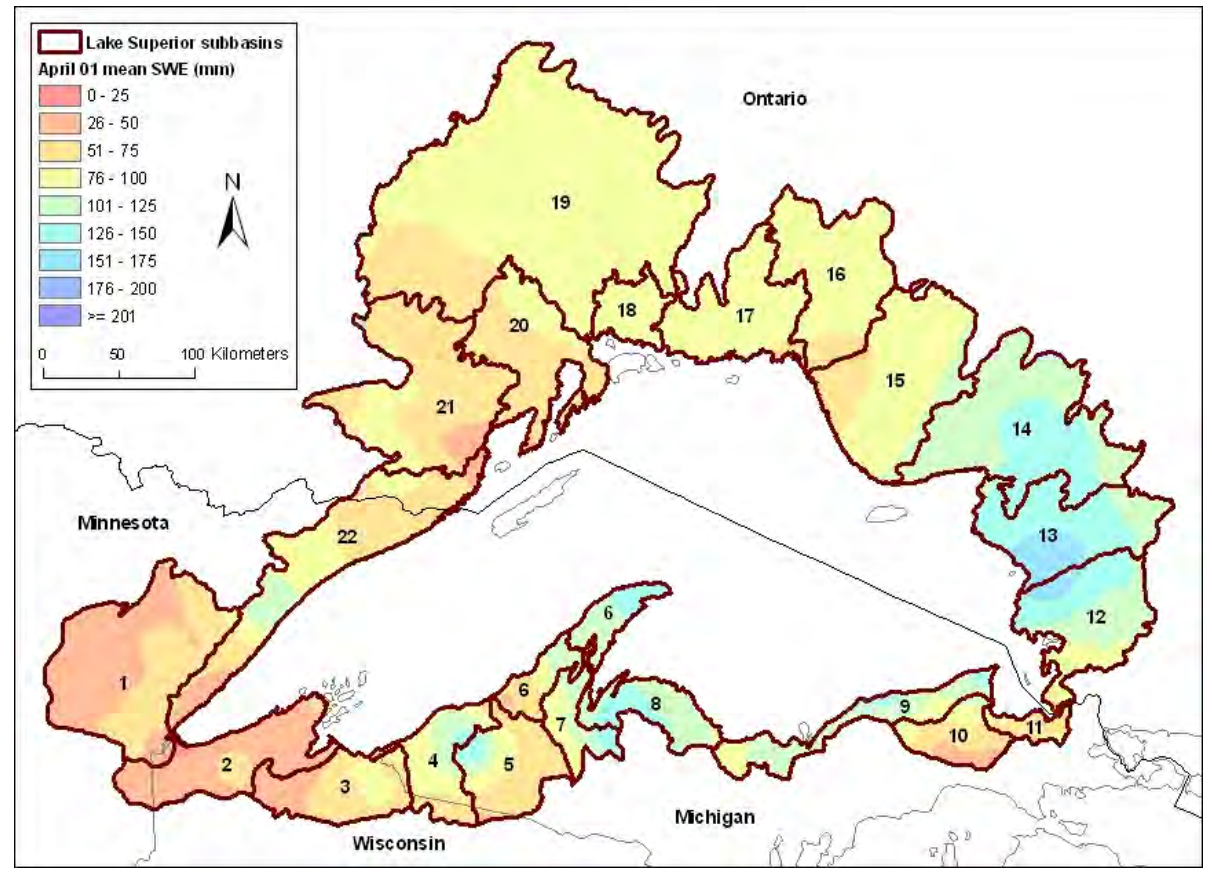

j. 1 April.

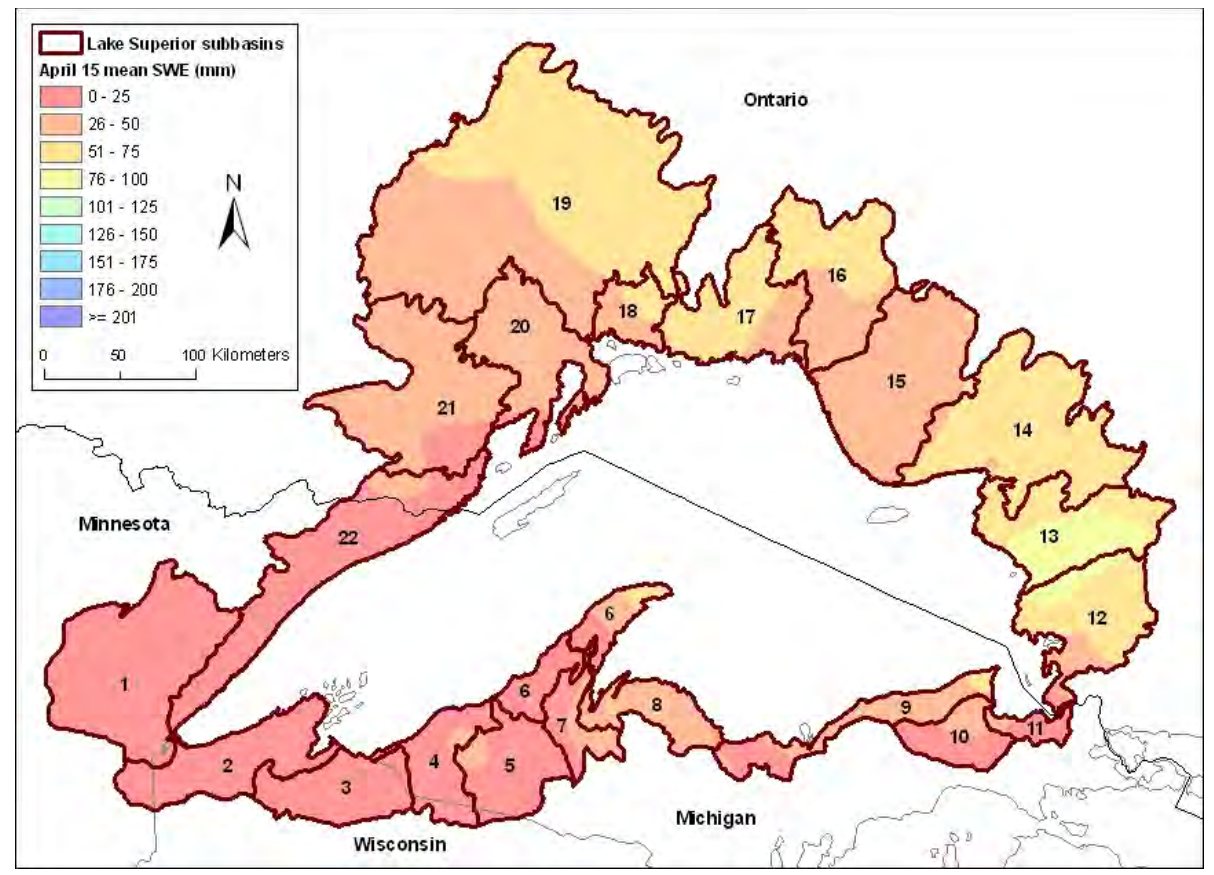

k. 15 April.

Figure 20 (cont'd). Mean SWE Distribution for the entire Lake Superior watershed for the $1^{\text {st }}$ and $15^{\text {th }}$ of each month throughout the winter season. 


\section{Summary}

This report investigated the historical spatial and temporal distribution of snow water equivalent (SWE) in the Lake Superior watershed using ground based measurements and GIS techniques. This report covers the winter seasons from the 1979- 80 through 2002- 03. Each winter season covered the period from 1 December through 30 April. These estimates were made on the basis of numerous ground-based daily observations collected and compiled by the National Weather Service (NOAA 2001, 2005) in the United States and compiled by the Meteorological Service of Canada (MSC 2000). The large majority of the observations were daily measurements of snow depth and not SWE. To make maximum use of the available snow observations, the SWE at each of these stations was estimated from the observed snow depth and an estimated snow density. Different procedures were used to estimate the snow density in the U.S. and in Canada because of the very different observation protocols that were followed in each country. In both cases, if no observations of snow density were available within a specified distance and window of time around the snow depth observation, the long term monthly snow density was used. The long-term monthly snow density was estimated on the basis of historical data included in this study. Once the daily SWE had been estimated at every station, the results could be interpolated throughout the Lake Superior watershed using inverse distance weighting. The end result was a series of gridded estimates of the daily SWE distribution covering the period of the study.

These gridded estimates of SWE were then used to estimate the total volume of SWE for each of the Lake Superior sub-basins and the entire watershed for each day between 1 December and 30 April for 1980 through 2003. These results were then used to analyze the Lake Superior watershed seasonal snow cover. Results include determining the annual accumulation and melt period characteristics, the annual series of maximum SWE volume, and comparing the annual maximum SWE volume with the incremental accumulated SWE volume. Selected results are also shown for the individual sub-basins. Maps were also prepared of the mean SWE distributions on the $1^{\text {st }}$ and $15^{\text {th }}$ day of each month. 


\section{References}

Croley, T. E., II, Hunter, T. S., and Martin, S. K. 2001. Great Lakes monthly hydrologic data. National Oceanic and Atmospheric Administration. NOAA Technical Report TM-083. [Update from Croley, T. E. II, and Hunter, T. S. 1994. Great Lakes monthly hydrologic data. NOAA Technical Report TM-083.]

ESRI. 2005. ESRI Data and Maps 2005 (DVDs).

International J oint Commission. 2006. Lake Superior Board of Control Mandate. Washington, D.C. Digital Media.

http:// www.ijc.org/ conseil_board/superior_lake/ en/superior_mandate_manda t.htm

MSC. 2000. Canadian snow data CD-ROM. CRYSYS Project, Climate Processes and Earth Observation Division, Meteorological Service of Canada, Downsview, Ontario.

Neff, B. P., and Nicholas, J . R. 2005. Uncertainty in the Great Lakes water balance. U.S. Geological Survey, Scientific Investigations Report 2004-5100.

NOAA. 2001. Cooperative summary of the day data POR- 2001. Asheville, NC: National Climatic Data Center.

http:// www.ncdc.noaa.gov/ oa/ climate/ climatedata.html

NOAA. 2005. U.S. summary of day data (DS3200/3210) 2002-2004. Asheville, NC:

National Climatic Data Center.

http:// www.ncdc.noaa.gov/ oa/ climate/ climatedata.html

Ochs, E. S. 2005. CRREL ArcGIS Tools: Gage Analyst and Storm Transform [computer software]. U.S. Army Engineer Research and Development Center, Cold Regions Research and Engineering Laboratory, Hanover, New Hampshire.

USGS. 2006. North American Atlas-Political Boundaries. U.S. Geological Survey, Instituto Nacional de Estadística Geografía e Informática, and Government of Canada. 


\section{APPENDIX A: SWE Stations in the U.S.}

$\begin{array}{lllllll}\text { STATION ID } & \text { STATION NAME } & \text { START YEAR } & \text { END YEAR } & \text { LAT } & \text { LONG } & \text { ELEV }(\mathrm{m}) \\ 207366 & \text { SAULT STE MARIE WSO } & 1979 & 1994 & 46.487 & -84.403 & 220.1 \\ 212248 & \text { DULUTH INTL AP } & 1979 & 2004 & 46.837 & -92.183 & 436.8\end{array}$




\section{APPENDIX B: Snow Depth Stations in the U.S.}

$\begin{array}{ll}\text { STATION ID } & \text { STATION NAME } \\ 200089 & \text { ALBERTA FORD FOR CEN } \\ 200197 & \text { AMASA 1 W } \\ 200485 & \text { BARAGA } \\ 200647 & \text { BEECHWOOD 7 WNW } \\ 200718 & \text { BERGLAND DAM } \\ 200770 & \text { BIG BAY 2 SE } \\ 201439 & \text { CHAMPION VAN RIPER P } \\ 201484 & \text { CHATHAM EXPERIMENT F } \\ 201486 & \text { CHATHAM EXP FARM 2 } \\ 201777 & \text { COPPER HARBOR 3 WNW } \\ 201780 & \text { COPPER HARBOR FT WIL } \\ 201800 & \text { CORNELL 4 WSW } \\ 201802 & \text { CORNELL 5 SE } \\ 201922 & \text { CRYSTAL FALLS 6 NE } \\ 202094 & \text { DETOUR VILLAGE } \\ 202298 & \text { DUNBAR FOREST EXP ST } \\ 202626 & \text { ESCANABA } \\ 203319 & \text { GRAND MARAIS 2 E } \\ 203639 & \text { HARVEY } \\ 203744 & \text { HERMAN } \\ 203908 & \text { HOUGHTON FAA AIRPORT } \\ 203917 & \text { HOUGHTON MTU } \\ 204104 & \text { IRONWOOD } \\ 204127 & \text { ISHPEMING } \\ 204328 & \text { KENTON } \\ 205073 & \text { MANISTIQUE } \\ 205178 & \text { MARQUETTE } \\ 205184 & \text { MARQUETTE WSO AP } \\ 205637 & \text { MOTT ISLAND ISLE ROY } \\ 205690 & \text { MUNISING } \\ 205759 & \text { NAUBINWAY 6 E } \\ 205816 & \text { NEWBERRY 3 S } \\ 206220 & \text { ONTONAGON 6 SE } \\ 206686 & \text { PORT INLAND } \\ 207068 & \text { ROCK 1 E } \\ 207190 & \text { RUDYARD 4N } \\ & \\ 2019 & \\ 2019 & \end{array}$

$\begin{array}{lllll}\text { START } & \text { END } & & & \\ \text { YEAR } & \text { YEAR } & \text { LAT } & \text { LONG } & \text { ELEV (m) } \\ 1957 & 1997 & 46.650 & -88.483 & 399.3 \\ 1999 & 2004 & 46.235 & -88.454 & 448.1 \\ 1967 & 1987 & * 46.783 & -88.483 & 195.1 \\ 1949 & 1990 & 46.183 & -88.883 & 506.0 \\ 1948 & 2004 & 46.587 & -89.548 & 396.2 \\ 1965 & 1999 & 46.798 & -87.707 & 198.1 \\ 1949 & 2004 & 46.519 & -87.986 & 487.4 \\ 1948 & 1988 & 46.350 & -86.933 & 268.2 \\ 1987 & 2004 & 46.347 & -86.929 & 265.2 \\ 1979 & 1984 & 47.483 & -87.950 & 192.0 \\ 1948 & 2004 & * 47.468 & -87.867 & 190.5 \\ 1963 & 1991 & 45.883 & -87.300 & 268.2 \\ 1991 & 2004 & 45.827 & -87.159 & 243.5 \\ 1948 & 1989 & * 46.167 & -88.233 & 414.5 \\ 1948 & 2004 & 45.998 & -83.901 & 181.4 \\ 1948 & 1990 & 46.317 & -84.233 & 182.9 \\ 1948 & 2004 & * 45.750 & -87.033 & 180.1 \\ 1948 & 2004 & 46.667 & -85.950 & 190.2 \\ 2002 & 2004 & 46.491 & -87.355 & \text { missing } \\ 1968 & 2004 & 46.667 & -88.350 & 530.4 \\ 1952 & 2000 & 47.168 & -88.489 & 327.4 \\ 1993 & 2003 & 47.117 & -88.550 & 259.1 \\ 1948 & 2004 & 46.467 & -90.183 & 435.9 \\ 1948 & 1987 & 46.483 & -87.650 & 438.9 \\ 1948 & 2002 & * 46.483 & -88.883 & 355.7 \\ 1948 & 2004 & 45.951 & -86.251 & 189.0 \\ 1948 & 2004 & 46.550 & -87.383 & 202.7 \\ 1959 & 2004 & * 46.531 & -87.549 & 431.3 \\ 1948 & 2004 & * 48.100 & -88.550 & 185.9 \\ 1948 & 2004 & 46.412 & -86.663 & 207.3 \\ 2000 & 2000 & 46.091 & -85.322 & 179.5 \\ 1948 & 2004 & 46.313 & -85.511 & 259.1 \\ 1977 & 2004 & 46.833 & -89.200 & 240.8 \\ 1953 & 1989 & 45.967 & -85.867 & 185.9 \\ 1948 & 1990 & 46.067 & -87.150 & 286.5 \\ 1978 & 2004 & 46.296 & -84.576 & 229.8\end{array}$




\begin{tabular}{|c|c|c|c|c|c|c|c|}
\hline STATION ID & STATION NAME & $\begin{array}{l}\text { START } \\
\text { YEAR }\end{array}$ & $\begin{array}{l}\text { END } \\
\text { YEAR }\end{array}$ & & LAT & LONG & $\operatorname{ELEV}(\mathrm{m})$ \\
\hline 207274 & ST IGNACE MACKINAC B & 1974 & 2004 & & 45.849 & -84.723 & 181.4 \\
\hline 207277 & ST JAMES 4SSW BEAVER & 1952 & 2004 & * & 45.691 & -85.546 & 204.8 \\
\hline 207364 & SAULT STE MARIE & 1998 & 2004 & & 46.487 & -84.403 & 192.0 \\
\hline 207366 & SAULT STE MARIE SNDR & 1948 & 2000 & * & 46.479 & -84.357 & 220.1 \\
\hline 207515 & SENEY WILDLIFE REFUG & 1961 & 2000 & & 46.283 & -85.950 & 216.4 \\
\hline 207812 & STAMBAUGH 2 SSE & 1948 & 2004 & & 46.056 & -88.628 & 442.0 \\
\hline 207880 & STEUBEN & 1948 & 1989 & & 46.183 & -86.467 & 225.6 \\
\hline 208043 & TAHQUAMENON FALLS ST & 1968 & 2004 & & 46.601 & -85.224 & 227.1 \\
\hline 208293 & TROUT LAKE 2 WNW & 1948 & 2004 & * & 46.199 & -85.073 & 265.5 \\
\hline 208680 & WATERSMEET 5 W & 1948 & 1999 & & 46.289 & -89.284 & 495.3 \\
\hline 208920 & WHITEFISH POINT & 1952 & 2004 & & 46.753 & -84.979 & 184.4 \\
\hline 210059 & AITKIN 2E & 1948 & 2004 & & 46.534 & -93.703 & 370.3 \\
\hline 210387 & BABBITT & 1999 & 2004 & & 47.710 & -91.944 & 454.8 \\
\hline 210390 & BABBITT 2 SE & 1948 & 1986 & & 47.683 & -91.917 & 192.0 \\
\hline 210754 & BIGFORK 5 ESE & 1948 & 1980 & * & 47.700 & -93.550 & 430.1 \\
\hline 210989 & BRIMSON 1E & 1948 & 2004 & * & 47.285 & -91.858 & 461.8 \\
\hline 211074 & BRUNO 7ENE & 1990 & 2004 & & 46.301 & -92.541 & 257.6 \\
\hline 211630 & CLOQUET & 1949 & 2004 & & 46.705 & -92.525 & 385.6 \\
\hline 211771 & $\mathrm{COOK}$ & 1999 & 2004 & & 47.851 & -92.693 & 413.0 \\
\hline 211773 & $\operatorname{coOK} 12 \mathrm{~W}$ & 1997 & 1999 & & 47.879 & -92.933 & 399.9 \\
\hline 211776 & COOK $18 \mathrm{~W}$ & 1959 & 1995 & & 47.867 & -93.067 & 400.8 \\
\hline 211840 & COTTON & 1962 & 2002 & & 47.170 & -92.467 & 405.1 \\
\hline 212246 & DULUTH HARBOR STA & 1960 & 1997 & & 46.768 & -92.090 & 185.9 \\
\hline 212248 & DULUTH INTL AP & 1948 & 2004 & & 46.837 & -92.183 & 436.8 \\
\hline 212543 & ELY & 1997 & 2004 & & 47.924 & -91.859 & 421.2 \\
\hline 212555 & ELY $25 \mathrm{E}$ & 1998 & 2004 & & 47.975 & -91.456 & 425.2 \\
\hline 212576 & EMBARRASS & 1994 & 2004 & & 47.658 & -92.196 & 426.7 \\
\hline 212645 & EVELETH WASTE WATER & 1986 & 2004 & & 47.458 & -92.530 & 440.4 \\
\hline 212842 & FLOODWOOD 3 NE & 1986 & 2004 & & 46.973 & -92.870 & 384.0 \\
\hline 213282 & GRAND MARAIS & 1948 & 2004 & & 47.739 & -90.361 & 186.5 \\
\hline 213296 & GRAND PORTAGE RNG ST & 1958 & 2004 & * & 47.971 & -89.691 & 222.5 \\
\hline 213303 & GRAND RAPIDS FORESTR & 1948 & 2004 & & 47.244 & -93.498 & 399.3 \\
\hline 213417 & GUNFLINT LAKE 10 NW & 1961 & 2004 & * & 48.160 & -90.877 & 443.5 \\
\hline 213727 & HIBBING POWER SUBSTN & 1948 & 1981 & * & 47.433 & -92.967 & 467.0 \\
\hline 213730 & HIBBING FAA AIRPORT & 1962 & 2000 & & 47.387 & -92.839 & 410.6 \\
\hline 213793 & HINCKLEY & 1948 & 2004 & & 45.992 & -92.993 & 315.5 \\
\hline 213921 & HOYT LAKES $5 \mathrm{~N}$ & 1958 & 1984 & & 47.583 & -92.133 & 463.9 \\
\hline 214068 & ISABELLA $1 \mathrm{~W}$ & 1957 & 2004 & * & 47.618 & -91.375 & 612.6 \\
\hline 214096 & ISLAND LAKE RESERVOI & 1948 & 1995 & * & 46.983 & -92.233 & 418.2 \\
\hline 214918 & LUTSEN 3NNE & 1986 & 2004 & & 47.698 & -90.666 & 396.2 \\
\hline
\end{tabular}




\begin{tabular}{|c|c|c|c|c|c|c|}
\hline STATION ID & STATION NAME & $\begin{array}{l}\text { START } \\
\text { YEAR }\end{array}$ & $\begin{array}{l}\text { END } \\
\text { YEAR }\end{array}$ & LAT & LONG & $\operatorname{ELEV}(\mathrm{m})$ \\
\hline 215175 & MARCELL 5 NE & 1981 & 2004 & * 47.631 & -93.652 & 422.8 \\
\hline 215298 & MEADOWLANDS $9 \mathrm{~S}$ & 1948 & 1985 & 46.983 & -92.733 & 386.8 \\
\hline 215598 & MOOSE LAKE 1 SSE & 1948 & 2004 & 46.438 & -92.758 & 338.3 \\
\hline 216612 & POKEGAMA DAM & 1948 & 2004 & 47.251 & -93.586 & 390.1 \\
\hline 216849 & REMER NO 2 & 1957 & 2000 & * 47.062 & -93.915 & 410.0 \\
\hline 216929 & RICE LAKE NWR & 1992 & 2004 & 46.538 & -93.284 & 381.0 \\
\hline 217460 & SANDY LAKE DAM LIBBY & 1948 & 2004 & 46.795 & -93.321 & 376.1 \\
\hline 218307 & TOWER DNR & 1994 & 2004 & 47.794 & -92.279 & 432.8 \\
\hline 218311 & TOWER $3 \mathrm{~S}$ & 1948 & 2004 & 47.755 & -92.286 & 445.0 \\
\hline 218419 & TWO HARBORS & 1948 & 2004 & 47.026 & -91.665 & 190.5 \\
\hline 218421 & TWO HARBORS 7 NW & 1998 & 2004 & 47.125 & -91.707 & 413.0 \\
\hline 218543 & VIRGINIA & 1948 & 1987 & * 47.500 & -92.550 & 438.9 \\
\hline 218939 & WHITEFACE RESERVOIR & 1948 & 1995 & * 47.283 & -92.183 & 454.8 \\
\hline 219101 & WINTON POWER PLANT & 1948 & 1995 & * 47.933 & -91.767 & 407.5 \\
\hline 219134 & WOLF RIDGE E L C & 1993 & 2004 & 47.450 & -91.217 & 426.7 \\
\hline 219173 & WRIGHT 4 NW & 1961 & 2004 & 46.718 & -93.070 & 394.7 \\
\hline 470347 & ASHLAND $3 \mathrm{~S}$ & 1998 & 2004 & 46.552 & -90.916 & 251.8 \\
\hline 470349 & ASHLAND EXP FARM & 1948 & 2004 & 46.573 & -90.971 & 198.1 \\
\hline 470603 & BAYFIELD $6 \mathrm{~N}$ & 1948 & 2004 & 46.883 & -90.817 & 249.9 \\
\hline 471131 & BRULE R S & 1948 & 2004 & 46.538 & -91.592 & 304.8 \\
\hline 471139 & BRULE ISLAND & 1948 & 1989 & 45.950 & -88.217 & 381.0 \\
\hline 471155 & BUCKATABON & 1948 & 2004 & 46.023 & -89.308 & 502.9 \\
\hline 471249 & BUTTERNUT $3 \mathrm{~N}$ & 1997 & 2004 & 46.054 & -90.522 & 474.6 \\
\hline 471618 & CLAM LAKE 10SW & 1998 & 2004 & 46.046 & -91.070 & 419.7 \\
\hline 471847 & COUDERAY $7 \mathrm{~W}$ & 1948 & 2004 & * 45.800 & -91.459 & 396.2 \\
\hline 471978 & DANBURY & 1948 & 2004 & 46.008 & -92.370 & 281.9 \\
\hline 472240 & DRUMMOND & 1948 & 2004 & * 46.333 & -91.267 & 408.4 \\
\hline 472314 & EAGLE RIVER & 1948 & 2004 & * 45.909 & -89.253 & 501.4 \\
\hline 472814 & FLAMBEAU RESERVOIR & 1948 & 1981 & 46.067 & -90.233 & 478.8 \\
\hline 472826 & FLORENCE & 1997 & 2004 & 45.925 & -88.257 & 397.8 \\
\hline 472889 & FOXBORO & 1963 & 2004 & * 46.486 & -92.288 & 284.1 \\
\hline 473186 & GORDON & 1951 & 2004 & 46.245 & -91.805 & 317.0 \\
\hline 473332 & GURNEY & 1952 & 2004 & 46.474 & -90.511 & 295.7 \\
\hline 473511 & HAYWARD RANGER STA & 1948 & 2004 & 46.000 & -91.508 & 365.8 \\
\hline 473636 & HILES & 1999 & 2004 & 45.681 & -88.960 & 497.7 \\
\hline 473800 & HURLEY & 1987 & 2004 & 46.462 & -90.193 & 295.7 \\
\hline 474383 & LAC VIEUX DESERT & 1948 & 2004 & 46.121 & -89.119 & 515.1 \\
\hline 474829 & LONG LAKE DAM & 1948 & 2001 & 45.888 & -89.139 & 496.8 \\
\hline 474953 & MADELINE ISLAND & 1948 & 2004 & 46.783 & -90.767 & 201.2 \\
\hline 475286 & MELLEN 4 NE & 1948 & 2004 & 46.369 & -90.642 & 396.2 \\
\hline
\end{tabular}




$\begin{array}{ll}\text { STATION ID } & \text { STATION NAME } \\ 475516 & \text { MINOCQUA DAM } \\ 475525 & \text { MINONG 5 WSW } \\ 475863 & \text { NEWALD 4 N } \\ 476122 & \text { NORTH PELICAN } \\ 476398 & \text { PARK FALLS DNR HQ } \\ 476413 & \text { PATTISON STATE PARK } \\ 476518 & \text { PHELPS } \\ 476772 & \text { PORT WING } \\ 476939 & \text { RAINBOW RSVR-LK TOMA } \\ 477092 & \text { REST LAKE } \\ 477113 & \text { RHINELANDER } \\ 477115 & \text { RHINELANDER 4 NE } \\ 477480 & \text { ST GERMAIN 2 E } \\ 477892 & \text { SOLON SPRINGS } \\ 478288 & \text { SUGAR CAMP } \\ 478349 & \text { SUPERIOR } \\ 478478 & \text { THREE LAKES 10 SE } \\ 478750 & \text { UPSON } \\ 479012 & \text { WEBSTER 9 SE } \\ 479236 & \text { WILLOW RESERVOIR } \\ 479304 & \text { WINTER }\end{array}$

\begin{tabular}{|c|c|c|c|c|c|}
\hline $\begin{array}{l}\text { START } \\
\text { YEAR }\end{array}$ & $\begin{array}{l}\text { END } \\
\text { YEAR }\end{array}$ & & LAT & LONG & $\operatorname{ELEV~(m)~}$ \\
\hline 1948 & 2004 & & 45.875 & -89.728 & 481.6 \\
\hline 1961 & 2004 & * & 46.067 & -91.867 & 327.7 \\
\hline 1959 & 1996 & & 45.783 & -88.700 & 469.4 \\
\hline 1948 & 2004 & & 45.636 & -89.242 & 490.7 \\
\hline 1948 & 2004 & & 45.934 & -90.451 & 464.8 \\
\hline 1998 & 2004 & & 46.537 & -92.119 & 335.3 \\
\hline 1948 & 2004 & & 46.066 & -89.076 & 541.3 \\
\hline 1948 & 2004 & * & 46.778 & -91.386 & 198.4 \\
\hline 1948 & 1996 & & 45.834 & -89.549 & 487.7 \\
\hline 1948 & 2004 & & 46.121 & -89.876 & 490.7 \\
\hline 1948 & 2004 & & 45.622 & -89.423 & 481.6 \\
\hline 2001 & 2004 & & 45.646 & -89.305 & 483.1 \\
\hline 1971 & 2004 & & 45.907 & -89.436 & 501.4 \\
\hline 1948 & 2004 & & 46.350 & -91.817 & 329.2 \\
\hline 1948 & 2003 & & 45.865 & -89.382 & 489.2 \\
\hline 1948 & 2004 & & 46.700 & -92.017 & 192.0 \\
\hline 1948 & 1997 & * & 45.713 & -89.003 & 524.3 \\
\hline 1998 & 2004 & & 46.368 & -90.412 & 456.3 \\
\hline 1998 & 2004 & & 45.788 & -92.233 & 306.3 \\
\hline 1948 & 2004 & & 45.709 & -89.853 & 475.5 \\
\hline 1948 & 2004 & & 45.823 & -91.014 & 425.8 \\
\hline
\end{tabular}

*Indicates non-continuous record. 


\section{APPENDIX C: SWE Stations in Canada}

\begin{tabular}{|c|c|c|c|c|c|c|c|c|c|}
\hline STATION ID & STATION NAME & LAT & LONG & $\begin{array}{l}\text { ELEV } \\
(\mathrm{m})\end{array}$ & $\begin{array}{l}\text { START } \\
\text { YR }\end{array}$ & $\begin{array}{l}\text { END } \\
\text { YR }\end{array}$ & & $\begin{array}{l}\text { ACTUAL } \\
\text { START }\end{array}$ & $\begin{array}{l}\text { ACTUAL } \\
\text { END }\end{array}$ \\
\hline ONR-0608 & ADAMSVILLE & 44.8667 & -81.1667 & 229.0 & 1981 & 1982 & & 27-Nov-81 & 2-Apr-82 \\
\hline ONR-0609 & COLPOY BAY 2 & 44.8000 & -81.1667 & 213.0 & 1982 & 2003 & & 1-Dec-82 & 16-Feb-04 \\
\hline ONR-1401 & HAZELWOOD L & 48.5833 & -89.3000 & 442.0 & 1973 & 2003 & & 9-Feb-73 & 16-Feb-04 \\
\hline ONR-1501 & THUNDER BAY & 48.4667 & -89.2500 & 244.0 & 1973 & 2003 & & 9-Feb-73 & 16-Feb-04 \\
\hline ONR-1601 & ROSSLYN & 48.3833 & -89.4333 & 229.0 & 1973 & 2003 & & 9-Feb-73 & 16-Feb-04 \\
\hline ONR-1701 & FORT CREEK & 46.5333 & -84.3500 & 213.0 & 1973 & 1981 & & 4-Feb-73 & 15-Apr-81 \\
\hline ONR-1702 & SHERWOOD FOR & 46.5500 & -84.3500 & 229.0 & 1973 & 1980 & & 4-Feb-73 & 15-Dec-80 \\
\hline ONR-1703 & FOURTH LINE & 46.5667 & -84.3333 & 243.0 & 1980 & 2003 & & 15-Dec-80 & 16-Feb-04 \\
\hline ONR-1801 & RED PINE & 46.5833 & -84.2833 & 282.0 & 1973 & 2003 & & 4-Feb-73 & 16-Feb-04 \\
\hline ONR-1802 & WISHART PARK & 46.5667 & -84.2833 & 221.0 & 1973 & 1980 & & 4-Feb-73 & 15-Dec-80 \\
\hline ONR-1901 & W. CEMETARY & 46.5667 & -84.4000 & 229.0 & 1973 & 1980 & & 6-Feb-73 & 1-Apr-80 \\
\hline ONR-1902 & EAST KORAH & 46.5500 & -84.4000 & 221.0 & 1973 & 2003 & & 18-Dec-73 & 16-Dec-03 \\
\hline ONR-1903 & E.DAVIGON CR & 46.5500 & -84.3667 & 198.0 & 1980 & 1981 & & 14-Dec-79 & 15-Apr-81 \\
\hline ONR-1904 & BENNET CR & 46.5333 & -84.4000 & 191.0 & 1980 & 1981 & & 14-Dec-79 & 15-Apr-81 \\
\hline ONR-1905 & BRULE ROAD & 46.5833 & -84.3667 & 274.0 & 1980 & 2003 & & 15-Dec-80 & 16-Dec-03 \\
\hline ONR-1906 & LEIGH'S BAY & 46.5500 & -84.3667 & 198.0 & 1980 & 2003 & & 15-Dec-80 & 2-Dec-03 \\
\hline ONR-1907 & WALLS ROAD & 46.5000 & -84.5167 & 213.0 & 1980 & 2003 & & 15-Dec-80 & 16-Dec-03 \\
\hline ONR-6001 & MARTEN RIVER & 46.7333 & -79.8000 & 305.0 & 1980 & 2003 & & 1-Mar-80 & 15-Apr-03 \\
\hline ONR-6002 & AFTON & 46.9667 & -80.3333 & 351.0 & 1980 & 2003 & * & 14-Mar-80 & 15-Apr-03 \\
\hline ONR-6003 & DANA TWP & 46.7000 & -80.2833 & 259.0 & 1981 & 2003 & * & 13-Jan-81 & 15-Apr-03 \\
\hline ONR-6004 & FELIX & 47.2333 & -81.4000 & 411.0 & 1981 & 2003 & * & 2-Mar-81 & 15-Apr-03 \\
\hline ONR-6007 & THOR LAKE & 47.1000 & -81.2667 & 427.0 & 1989 & 1989 & & 1-Mar-89 & 1-May-89 \\
\hline ONR-6008 & GIBBONS TWP & 46.5500 & -80.0667 & 256.0 & 1989 & 2003 & * & 3-Mar-89 & 15-Apr-03 \\
\hline ONR-6101 & CHAUDIERE D & 46.1167 & -80.0333 & 198.0 & 1981 & 2003 & * & 15-Dec-81 & 16-Dec-03 \\
\hline ONR-6102 & BURWASH & 46.2667 & -80.7500 & 241.0 & 1987 & 1989 & & $16-F e b-87$ & 1-May-89 \\
\hline ONR-6201 & GORDON CHUTE & 46.4833 & -81.9667 & 366.0 & 1980 & 1986 & & 4-Mar-80 & 14-Mar-86 \\
\hline ONR-6202 & SEARCHMONT & 46.8167 & -84.0000 & 281.0 & 1983 & 2003 & & 28-Feb-83 & 16-Dec-03 \\
\hline ONR-6203 & RITCHIE FALL & 46.7667 & -82.2833 & 465.0 & 1985 & 1993 & & 16-Dec-85 & 1-May-93 \\
\hline ONR-6301 & TEMAGAMI & 47.0500 & -79.8167 & 298.0 & 1982 & 2003 & * & 15-Jan-82 & 15-Apr-03 \\
\hline ONR-6302 & HERRIDGE & 46.9833 & -79.8000 & 321.0 & 1987 & 1988 & & 15-Dec-87 & 15-Apr-88 \\
\hline ONR-6401 & MCFARLANE LAKE & 46.4167 & -80.9500 & 230.0 & 1982 & 1993 & & 1-Feb-82 & 30-Dec-93 \\
\hline ONR-6402 & CAPREOL PARK & 46.7167 & -80.9500 & 310.0 & 1982 & 2003 & & 14-Dec-82 & 1-Apr-03 \\
\hline ONR-6403 & NIKLEDALE & 46.5333 & -80.9833 & 270.0 & 1982 & 1984 & & 15-Dec-82 & 15-Apr-84 \\
\hline ONR-6404 & OFFSET RD. & 46.6500 & -81.2167 & 270.0 & 1982 & 1997 & & 15-Dec-82 & 16-Dec-97 \\
\hline ONR-6405 & STOBIE DAM & 46.5333 & -81.2833 & 260.0 & 1982 & 2003 & & 15-Dec-82 & 1-Apr-03 \\
\hline ONR-6406 & ESTAIRE & 46.3000 & -80.8167 & 250.0 & 1991 & 2003 & * & 1-Mar-91 & 2-Jan-03 \\
\hline
\end{tabular}




\begin{tabular}{|c|c|c|c|c|c|c|c|c|c|}
\hline STATION ID & STATION NAME & LAT & LONG & $\begin{array}{l}\text { ELEV } \\
(\mathrm{m})\end{array}$ & $\begin{array}{l}\text { START } \\
\text { YR }\end{array}$ & $\begin{array}{l}\text { END } \\
\text { YR }\end{array}$ & & $\begin{array}{l}\text { ACTUAL } \\
\text { START }\end{array}$ & $\begin{array}{l}\text { ACTUAL } \\
\text { END }\end{array}$ \\
\hline ONR-6407 & GARSON & 46.5167 & -80.8500 & missing & 1998 & 2003 & & 3-Feb-98 & 1-Apr-03 \\
\hline ONR-6501 & DUMP CAMP & 46.6500 & -82.8167 & 320.0 & 1980 & 1986 & & 5-Mar-80 & 28-Feb-86 \\
\hline ONR-6502 & COBRA LAKE & 46.7667 & -83.8333 & 412.0 & 1986 & 1996 & * & 1-Apr-86 & 28-Mar-96 \\
\hline SCD-MB170 & VASSAR D-9 & 49.0833 & -95.8333 & 360.0 & 1962 & 1985 & * & 14-Feb-62 & 12-Mar-85 \\
\hline SCD-MB184 & WEST HAWK LAKE D-5 & 49.7333 & -95.2167 & 335.0 & 1962 & 1985 & & 12-Feb-62 & 11-Mar-85 \\
\hline CD-MB186 & WHITEMOUTH D-3 & 49.2833 & -95.9500 & 287.0 & 1962 & 1985 & & 12-Feb-62 & 11-Mar-85 \\
\hline SCD-ONO01 & ABITIBI CANYON & 49.9167 & -81.5667 & 229.0 & 1956 & 1985 & * & 1-Jan-56 & 15-Apr-85 \\
\hline SCD-ONOO3 & ADAMSVILLE & 44.8667 & -81.1667 & 222.0 & 1976 & 1980 & & 15-Dec-76 & 15-Apr-78 \\
\hline SCD-ON005 & AFTON & 46.9667 & -80.3333 & 351.0 & 1980 & 1985 & & 14-Mar-80 & 22-Apr-85 \\
\hline SCD-ON006 & ALBERMARLE & 44.8667 & -81.1667 & 229.0 & 1981 & 1982 & & 27-Nov-81 & 2-Apr-82 \\
\hline SCD-ON011 & ARMSTRONG & 50.2833 & -89.0333 & 351.0 & 1956 & 1985 & * & 1-Jan-56 & 15-Apr-85 \\
\hline SD-ON018 & ATIKOKAN & 48.7500 & -91.6167 & 393.0 & 1956 & 1988 & & 5-Jan-56 & 1-Apr-88 \\
\hline CD-ON019 & AUBREY FALLS & 46 & -83 & 6.0 & 1956 & 1985 & * & -56 & $y-85$ \\
\hline SCD-ON036 & BENNET CR & 46.5333 & -84.4000 & 191.0 & 1980 & 1981 & & 15-Dec-80 & 15-Apr-81 \\
\hline SCD-ON041 & BISCOTASING & 47.3000 & -82.1000 & 411.0 & 1956 & 1985 & * & 1-Jan-56 & 1-May-85 \\
\hline SCD-ONO47 & BOLANDS BAY & 46.6333 & -81.7667 & 305.0 & 1961 & 1985 & & 1-Jan-63 & 15-Apr-85 \\
\hline SCD-ONO49 & BONIS EADES STATION & 48.9333 & -79.9333 & 269.0 & 1956 & 1985 & * & 31-Jan-56 & 1-Apr-85 \\
\hline SCD-ON061 & BRULE ROAD & 46.5833 & -84.3667 & 274.0 & 1980 & 1985 & & 15-Dec-80 & 16-Apr-85 \\
\hline SCD-ON065 & CAMERON FALLS & 49.1333 & -88.3833 & 238.0 & 1956 & 1985 & * & 1-Jan-56 & 15-Apr-85 \\
\hline SCD-ON071 & CAPREOL PARK & 46.7167 & -80.9500 & 310.0 & 1982 & 1985 & & 1-Dec-82 & 15-Apr-85 \\
\hline SCD-ON077 & CHALLIES WHITE WATER & 49.1167 & -80 & missing & 1965 & 1985 & & 3-Ja & 1-Apr-85 \\
\hline CD-ON078 & CHAPLEAU & 47.8167 & -83.4000 & 427.0 & 1956 & 1985 & & 1-Jan-56 & 15-Apr-85 \\
\hline SCD-ON079 & CHAUDIERE D & 46.1167 & -80.0333 & 198.0 & 1981 & 1985 & & 15-Dec-81 & 22-Apr-85 \\
\hline SCD-ON087 & COLPOY BAY & 44.8000 & -81.1667 & 213.0 & 1976 & 1985 & * & 15-Dec-76 & 2-Apr-84 \\
\hline SCD-ON104 & DINORWIC & 49.7000 & -92.5000 & 379.0 & 1956 & 1984 & * & 1-Mar-56 & 5-Mar-84 \\
\hline SCD-ON106 & DOG LAKE DAM & 48.7000 & -89.6167 & 427.0 & 1956 & 1985 & * & 1-Jan-56 & 15-Apr-85 \\
\hline SCD-ON107 & DUMP CAMP BRIDGE & 46.6500 & -82.8167 & 320.0 & 1981 & 1985 & & 1-Feb-81 & 17-Mar-85 \\
\hline SCD-ON110 & E DAVIGNON CR & 46.5500 & -84.3667 & 198.0 & 1980 & 1981 & & 14-Dec-79 & 15-Apr-81 \\
\hline SCD-ON112 & EAR FALLS & 50.6333 & -93.1833 & 366.0 & 1956 & 1985 & & 1-Jan-56 & 15-Apr-85 \\
\hline SCD-ON113 & EAST KORAH & 46.5500 & -84.4000 & 221.0 & 1973 & 1985 & & 18-Dec-73 & 16-Apr-85 \\
\hline SCD-ON123 & FELIX & 47.2333 & -81.4000 & 411.0 & 1981 & 1985 & & 2-Mar-81 & 23-Apr-85 \\
\hline SCD-ON126 & FIELD & 46.3667 & -80.0500 & 236.0 & 1956 & 1980 & * & 3-Mar-56 & 3-Mar-80 \\
\hline SCD-ON130 & FOLEYET & 48.2333 & -82.4000 & 326.0 & 1956 & 1985 & & 1-Jan-56 & 15-Apr-85 \\
\hline SCD-ON131 & FORT CREEK & 46.5333 & -84.3500 & 213.0 & 1973 & 1981 & & 4-Feb-73 & 15-Apr-81 \\
\hline SCD-ON132 & FORT FRANCES & 48.6167 & -93.3500 & 341.0 & 1956 & 1984 & * & 3-Jan-56 & 1-Apr-84 \\
\hline SCD-ON134 & FORTH LINE & 46.5667 & -84.3333 & 243.0 & 1980 & 1985 & & 30-Nov-80 & 16-Apr-85 \\
\hline SCD-ON136 & FREDERICKHOUSE DAM & 48.7167 & -80.9500 & 290.0 & 1956 & 1985 & * & 1-Jan-56 & 1-May-85 \\
\hline SCD-ON137 & FREELE MILE 28 & 49.0667 & -80.4667 & 312.0 & 1960 & 1985 & & 1-Feb-60 & 1-Apr-85 \\
\hline SCD-ON145 & GERALDTON & 49.7667 & -86.9167 & 335.0 & 1956 & 1985 & * & 1-Jan-56 & 15-Apr-85 \\
\hline SCD-ON146 & GHOST RIVER & 48.5333 & -79.8333 & 381.0 & 1963 & 1985 & & 1-Jan-63 & 1-May-85 \\
\hline
\end{tabular}




\begin{tabular}{|c|c|c|c|c|c|c|c|c|c|}
\hline STATION ID & STATION NAME & LAT & LONG & $\begin{array}{l}\text { ELEV } \\
(\mathrm{m})\end{array}$ & $\begin{array}{l}\text { START } \\
\text { YR }\end{array}$ & $\begin{array}{l}\text { END } \\
\text { YR }\end{array}$ & & $\begin{array}{l}\text { ACTUAL } \\
\text { START }\end{array}$ & $\begin{array}{l}\text { ACTUAL } \\
\text { END }\end{array}$ \\
\hline SCD-ON151 & GORDON CHUTES & 46.4833 & -81.9667 & 366.0 & 1980 & 1985 & & 4-Mar-80 & 15-Apr-85 \\
\hline SCD-ON155 & HAWK JUNCTION & 48.0500 & -84.5667 & 366.0 & 1971 & 1985 & & 1-Feb-79 & 15-Apr-85 \\
\hline SCD-ON157 & HAZELWOOD LAKE & 48.5833 & -89.3000 & 442.0 & 1973 & 1985 & & 9-Feb-73 & 17-Apr-85 \\
\hline SCD-ON158 & HEARST & 49.7833 & -84.1167 & 259.0 & 1956 & 1985 & & 1-Jan-56 & 2-May-85 \\
\hline SCD-ON169 & HUNTA & 49.1000 & -81.3000 & 274.0 & 1956 & 1985 & * & 1-Jan-56 & 15-Apr-85 \\
\hline SCD-ON172 & IGNACE & 48.7500 & -91.6333 & 452.0 & 1956 & 1984 & * & 1-Mar-56 & 5-Mar-84 \\
\hline SCD-ON173 & INDIAN CHUTE & 47.8333 & -80.4333 & 299.0 & 1956 & 1985 & * & 1-Jan-56 & 1-May-85 \\
\hline SCD-ON176 & KAPUSKASING & 49.4167 & -82.4500 & 225.0 & 1956 & 1985 & & 1-Jan-56 & 15-Apr-85 \\
\hline SCD-ON177 & KAPUSKASING A & 49.4167 & -82.4667 & 229.0 & 1962 & 1984 & * & 8-Jan-62 & 11-Dec-84 \\
\hline SCD-ON178 & KAPUSKASING CDA & 49.4000 & -82.4333 & 218.0 & 1966 & 2001 & * & 23-Nov-66 & 9-Apr-01 \\
\hline SCD-ON183 & KENORA & 49.7833 & -94.4833 & 335.0 & 1956 & 1985 & * & 1-Mar-56 & 1-Apr-85 \\
\hline SCD-ON190 & KORAH & 46.5500 & -84.4000 & 229.0 & 1973 & 1980 & & 6-Feb-73 & 29-Feb-80 \\
\hline SCD-ON193 & LADY EVELYN LAKE & 47.4667 & -79.9333 & 290.0 & 1957 & 1985 & * & 1-Jan-57 & 15-Apr-85 \\
\hline SCD-ON194 & LANSDOWNE HOUSE & 52.2333 & -87.8833 & 256.0 & 1965 & 1988 & & 15-Nov-65 & 23-Dec-88 \\
\hline SCD-ON196 & LEIGH'S BAY ROAD & 46.5500 & -84.3667 & 198.0 & 1980 & 1985 & & 15-Dec-80 & 16-Apr-85 \\
\hline SCD-ON201 & LONG LAKE CONTROL DA & 49.0833 & -87.0667 & 320.0 & 1956 & 1985 & * & 15-Jan-56 & 15-Apr-85 \\
\hline SCD-ON211 & MARTEN RIVER & 46.7333 & -79.8000 & 305.0 & 1980 & 1985 & & 1-Mar-80 & 15-Apr-85 \\
\hline SCD-ON213 & MATTAGAMI DAM & 48.0000 & -81.5667 & 335.0 & 1956 & 1985 & & 1-Jan-56 & 15-Apr-85 \\
\hline SCD-ON214 & MCFARLANE LAKE & 46.4167 & -80.9500 & 230.0 & 1982 & 1985 & & 1-Feb-82 & 15-Apr-85 \\
\hline SCD-ON221 & MILNET & 46.8167 & -80.9500 & 335.0 & 1956 & 1985 & * & 1-Mar-56 & 15-Apr-85 \\
\hline SCD-ON223 & MINE CENTRE & 48.7667 & -92.6000 & 366.0 & 1956 & 1984 & * & 1-Mar-56 & 5-Mar-84 \\
\hline SCD-ON225 & MISTINIKON DAM & 48.0500 & -80.7167 & 320.0 & 1956 & 1985 & * & 1-Jan-56 & 1-May-85 \\
\hline SCD-ON244 & NESTOR FALLS & 49.1167 & -93.9000 & 329.0 & 1956 & 1984 & * & 1-Mar-56 & 5-Mar-84 \\
\hline SCD-ON246 & NICKEL OFFSET ROAD & 46.6500 & -81.2167 & 260.0 & 1982 & 1985 & & 1-Dec-82 & 15-Apr-85 \\
\hline SCD-ON247 & NICKELDALE RESERVOIR & 46.5333 & -80.9833 & 270.0 & 1982 & 1984 & & 1-Dec-82 & 15-Apr-84 \\
\hline SCD-ON248 & NIGHTHAWK & 48.5500 & -80.9667 & 290.0 & 1956 & 1985 & * & 1-Jan-56 & 1-May-85 \\
\hline SCD-ON256 & OBA & 49.0667 & -84.1000 & 335.0 & 1956 & 1985 & * & 1-Jan-56 & 15-Apr-85 \\
\hline SCD-ON263 & PAGWACHUAN & 49.7667 & -85.2333 & 213.0 & 1965 & 1985 & * & 1-Feb-79 & 15-Apr-85 \\
\hline SCD-ON271 & PICKLE LAKE & 51.4667 & -90.2000 & 369.0 & 1967 & 2001 & * & 1-Mar-67 & 23-Apr-01 \\
\hline SCD-ON279 & QUIBELL & 49.9500 & -93.4000 & 350.0 & 1956 & 1984 & * & 1-Mar-56 & 5-Mar-84 \\
\hline SCD-ON280 & RAT RAPIDS & 51.1667 & -90.2167 & 375.0 & 1956 & 1985 & & 1-Jan-56 & 1-May-85 \\
\hline SCD-ON281 & RED CEDAR LAKE DAM & 46.6833 & -79.9833 & 259.0 & 1956 & 1985 & * & 1-Jan-56 & 1-May-85 \\
\hline SCD-ON282 & RED LAKE & 51.0167 & -93.8167 & 381.0 & 1956 & 1985 & * & 1-Jan-56 & 15-Apr-85 \\
\hline SCD-ON283 & RED PINE HIAWATHA & 46.5833 & -84.2833 & 282.0 & 1973 & 1985 & & 4-Feb-73 & 16-Apr-85 \\
\hline SCD-ON285 & REDROCK & 46.3333 & -83.3000 & 213.0 & 1956 & 1985 & * & 1-Jan-56 & 15-Apr-85 \\
\hline SCD-ON290 & ROSSLYN & 48.3833 & -89.4333 & 229.0 & 1973 & 1985 & & 9-Feb-73 & 14-Apr-85 \\
\hline SCD-ON293 & SAULT STE MARIE A & 46.4833 & -84.5000 & 192.0 & 1971 & 1995 & * & 18-Dec-71 & 23-Apr-95 \\
\hline SCD-ON295 & SAVANNE & 48.9667 & -90.2500 & 459.0 & 1956 & 1984 & * & 5-Jan-56 & 5-Mar-84 \\
\hline SCD-ON296 & SAVANT LAKE & 50.2333 & -90.6833 & 439.0 & 1956 & 1984 & * & 1-Mar-56 & 5-Mar-84 \\
\hline SCD-ON299 & SEARCHMONT & 46.8167 & -84.0000 & 281.0 & 1983 & 1985 & & 5-Dec-83 & 9-Apr-85 \\
\hline
\end{tabular}




\begin{tabular}{|c|c|c|c|c|c|c|c|c|c|}
\hline STATION ID & STATION NAME & LAT & LONG & $\begin{array}{l}\text { ELEV } \\
(\mathrm{m})\end{array}$ & $\begin{array}{l}\text { START } \\
\text { YR }\end{array}$ & $\begin{array}{l}\text { END } \\
\text { YR }\end{array}$ & & $\begin{array}{l}\text { ACTUAL } \\
\text { START }\end{array}$ & $\begin{array}{l}\text { ACTUAL } \\
\text { END }\end{array}$ \\
\hline SCD-ON304 & SHERWOOD FOREST & 46.5500 & -84.3500 & 213.0 & 1973 & 1980 & & 4-Feb-73 & 15-Dec-80 \\
\hline SCD-ON305 & SHILLINGTON & 48.5500 & -80.7000 & 290.0 & 1956 & 1985 & $*$ & 1-Jan-56 & 1-May-85 \\
\hline SCD-ON306 & SHININGTREE & 47.4833 & -81.4167 & 396.0 & 1957 & 1985 & * & 1-Jan-57 & 15-Apr-85 \\
\hline SCD-ON309 & SIOUX LOOKOUT & 50.1167 & -91.9167 & 375.0 & 1956 & 1985 & & 1-Jan-56 & 1-Apr-85 \\
\hline SCD-ON311 & SIOUX LOOKOUT A & 50.1167 & -91.9000 & 390.0 & 1966 & 1985 & $*$ & 15-Nov-66 & 23-Mar-85 \\
\hline SCD-ON313 & SOUTH PORCUPINE & 48.4167 & -81.1833 & 305.0 & 1956 & 1985 & * & 1-Jan-56 & 1-May-85 \\
\hline SCD-ON324 & STEELE MILE 50 & 49.0167 & -79.9833 & 381.0 & 1960 & 1985 & & 1-Feb-60 & 1-Apr-85 \\
\hline SCD-ON327 & STIMSON DIAMOND & 48.9667 & -80.6000 & 294.0 & 1960 & 1985 & & 1-Feb-60 & 1-Apr-85 \\
\hline SCD-ON330 & STOBIE DAM & 46.5333 & -81.2833 & 260.0 & 1982 & 1985 & & 1-Dec-82 & 15-Apr-85 \\
\hline SCD-ON335 & SUDBURY A & 46.6167 & -80.8000 & 347.0 & 1965 & 1996 & & 8-Dec-65 & 1-Apr-96 \\
\hline SCD-ON337 & TANNIN & 49.6500 & -91.0000 & 448.0 & 1956 & 1984 & & 1-Mar-56 & 5-Mar-84 \\
\hline SCD-ON341 & TEESWATER & 44.9500 & -81.3167 & 300.0 & 1979 & 1985 & & 15-Feb-79 & 15-Apr-85 \\
\hline SCD-ON342 & TEMAGAMI & 47.0500 & -79.8167 & 298.0 & 1983 & 1985 & & 15-Dec-83 & 1-May-85 \\
\hline SCD-ON343 & TEMAGAMI & 47.0500 & -79.8333 & 305.0 & 1956 & 1985 & & 1-Jan-56 & 1-May-85 \\
\hline SCD-ON347 & THUNDER BAY & 48.4667 & -89.2500 & 244.0 & 1973 & 1985 & & 9-Feb-73 & 1-Apr-85 \\
\hline SCD-ON348 & THUNDER BAY A & 48.3667 & -89.3167 & 199.0 & 1969 & 1986 & & 23-Nov-69 & 25-Mar-86 \\
\hline SCD-ON366 & WALLS ROAD & 46.5000 & -84.5167 & 213.0 & 1981 & 1985 & & 3-Dec-81 & 16-Apr-85 \\
\hline SCD-ON367 & WANAPITEI & 46.4667 & -80.7833 & 259.0 & 1956 & 1980 & & 5-Mar-56 & 3-Mar-80 \\
\hline SCD-ON373 & WAWAITIN & 48.4500 & -81.3333 & 320.0 & 1956 & 1985 & & 1-Jan-56 & 1-May-85 \\
\hline SCD-ON377 & WHITE RIVER & 48.6000 & -85.2833 & 381.0 & 1962 & 1985 & & 1-Jan-63 & 15-Apr-85 \\
\hline SCD-ON379 & WIG LAKE & 49.4000 & -87.1833 & 381.0 & 1963 & 1985 & & 1-Jan-63 & 15-Apr-85 \\
\hline SCD-ON386 & WISHART PARK & 46.5667 & -84.2833 & 221.0 & 1973 & 1980 & & 4-Feb-73 & 15-Dec-80 \\
\hline SCD-QC335 & VILLE MARIE & 47.3167 & -79.4333 & 244.0 & 1956 & 1985 & & 13-Jan-56 & 13-Apr-85 \\
\hline
\end{tabular}

* Indicates gaps in data. 


\section{APPENDIX D: Snow Depth Stations in Canada}

\begin{tabular}{|c|c|}
\hline STATION ID & STATION NAME \\
\hline 6012198 & EAR FALLS \\
\hline 6012199 & EAR FALLS (AUT) \\
\hline 6014350 & LANSDOWNE HOUSE \\
\hline 6014353 & LANSDOWNE HOUSE (AUT \\
\hline 6016525 & PICKLE LAKE (AUT) \\
\hline 6016527 & PICKLE LAKE A \\
\hline 6016975 & RED LAKE A \\
\hline 6020379 & ATIKOKAN \\
\hline 6020384 & ATIKOKAN MARMION \\
\hline 6020559 & BARWICK \\
\hline 6020727 & BERGLAND \\
\hline 6022010 & DEVLIN \\
\hline 6022011 & DEVLIN BELLAMY \\
\hline 6022475 & FORT FRANCES \\
\hline 6022476 & FORT FRANCES A \\
\hline 6025203 & MINE CENTRE \\
\hline 6026852 & RAINY RIVER \\
\hline 6027825 & SLEEMAN \\
\hline 6028125 & STRATTON \\
\hline 6028127 & STRATTON ROEN \\
\hline 6028128 & STRATTON ROMYN \\
\hline 6032117 & DRYDEN \\
\hline 6032119 & DRYDEN A \\
\hline 6032120 & DRYDEN 'A' (AUT) \\
\hline 6032192 & EAGLE RIVER \\
\hline 6033697 & IGNACE TCPL 58 \\
\hline 6034075 & KENORA A \\
\hline 6034077 & KENORA TCPL 49 \\
\hline 6035002 & MARTIN TCPL 60 \\
\hline 6036904 & RAWSON LAKE \\
\hline 6037775 & SIOUX LOOKOUT A \\
\hline 6039136 & VERMILION BAY TCPL 5 \\
\hline 6040010 & ABITIBI CAMP 11 \\
\hline 6040011 & ABITIBI CAMP 11 \\
\hline 6040020 & ABITIBI CAMP 230 \\
\hline 6040022 & ABITIBI CAMP 300 \\
\hline
\end{tabular}

\begin{tabular}{|c|c|c|c|c|c|}
\hline $\begin{array}{l}\text { START } \\
\text { YEAR }\end{array}$ & $\begin{array}{l}\text { END } \\
\text { YEAR }\end{array}$ & & LAT & LONG & $\begin{array}{l}\text { ELEV } \\
(\mathrm{m})\end{array}$ \\
\hline 1930 & 1996 & * & 50.630 & -93.220 & 360.9 \\
\hline 1999 & 2003 & & 50.630 & -93.220 & 362.6 \\
\hline 1941 & 1989 & & 52.230 & -87.880 & 254.5 \\
\hline 1993 & 2003 & & 52.200 & -87.940 & 253.4 \\
\hline 1930 & 1990 & * & 51.450 & -90.220 & 390.8 \\
\hline 990 & 2003 & & 51.450 & -90.220 & 386.2 \\
\hline 933 & 2003 & * & 51.070 & -93.790 & 385.6 \\
\hline-966 & 1988 & & 48.750 & -91.620 & 395.3 \\
\hline 1980 & 2003 & * & 48.800 & -91.580 & 442.0 \\
\hline 1979 & 2003 & & 48.630 & -93.970 & 335.0 \\
\hline 1980 & 1981 & & 48.950 & -94.350 & 363.9 \\
\hline 1979 & 1992 & & 48.520 & -93.750 & 335.0 \\
\hline 1979 & 1992 & & 48.630 & -93.670 & 347.2 \\
\hline 1892 & 1995 & * & 48.620 & -93.420 & 343.2 \\
\hline 1976 & 2003 & & 48.650 & -93.430 & 342.0 \\
\hline 1916 & 2003 & * & 48.770 & -92.620 & 342.9 \\
\hline 1916 & 2003 & * & 48.720 & -94.530 & 316.0 \\
\hline 1964 & 1991 & & 48.720 & -94.420 & 335.3 \\
\hline 1970 & 1986 & & 48.780 & -94.050 & 358.1 \\
\hline 1979 & 1983 & * & 48.850 & -94.020 & 347.2 \\
\hline 1979 & 2003 & & 48.700 & -94.170 & 366.1 \\
\hline 1914 & 1997 & * & 49.780 & -92.830 & 371.9 \\
\hline 1970 & 2003 & & 49.830 & -92.750 & 412.7 \\
\hline 2000 & 2002 & & 49.830 & -92.740 & 412.7 \\
\hline 1986 & 1988 & & 49.820 & -93.220 & 350.0 \\
\hline 1970 & 1993 & & 49.480 & -92.000 & 473.0 \\
\hline 1938 & 2003 & & 49.790 & -94.370 & 406.1 \\
\hline 1970 & 1990 & * & 49.780 & -94.480 & 340.2 \\
\hline 1970 & 1983 & & 49.280 & -91.230 & 470.6 \\
\hline 1969 & 2003 & & 49.650 & -93.720 & 358.1 \\
\hline 1938 & 2003 & & 50.120 & -91.900 & 383.4 \\
\hline 1970 & 1984 & & 49.830 & -93.630 & 385.0 \\
\hline 1978 & 1983 & 太 & 48.930 & -89.350 & 442.0 \\
\hline 1983 & 1988 & & 48.850 & -89.120 & 491.0 \\
\hline 1970 & 1982 & & 49.350 & -89.370 & 457.2 \\
\hline 1978 & 1986 & & 49.630 & -89.750 & 426.7 \\
\hline
\end{tabular}




\begin{tabular}{|c|c|c|c|c|c|c|c|}
\hline STATION ID & STATION NAME & $\begin{array}{l}\text { START } \\
\text { YEAR }\end{array}$ & $\begin{array}{l}\text { END } \\
\text { YEAR }\end{array}$ & & LAT & LONG & $\begin{array}{l}\text { ELEV } \\
\text { (m) }\end{array}$ \\
\hline 6040325 & ARMSTRONG (AUT) & 1938 & 2002 & * & 50.290 & -88.910 & 322.5 \\
\hline 6040330 & ARMSTRONG JELLIEN & 1987 & 1992 & & 50.250 & -89.100 & 341.4 \\
\hline 6040572 & BEARDMORE & 1974 & 1986 & * & 49.620 & -87.950 & 304.8 \\
\hline 6041109 & CAMERON FALLS & 1924 & 1998 & * & 49.150 & -88.350 & 228.6 \\
\hline 6041110 & CAMERON FALLS (AUT) & 1998 & 2003 & & 49.150 & -88.340 & 232.6 \\
\hline 6041193 & CARAMAT & 1949 & 1983 & * & 49.270 & -85.830 & 338.3 \\
\hline 6041221 & CARIBOU ISLAND & 1935 & 1988 & * & 47.330 & -85.830 & 186.5 \\
\hline 6042067 & DORION TCPL 70 & 1970 & 1984 & & 48.820 & -88.520 & 192.6 \\
\hline 6042715 & GERALDTON & 1967 & 1981 & & 49.700 & -86.950 & 330.7 \\
\hline 6042716 & GERALDTON A & 1981 & 2003 & & 49.780 & -86.930 & 348.7 \\
\hline 6043452 & HEMLO BATTLE MOUNTAI & 1985 & 2001 & & 48.700 & -85.880 & 335.0 \\
\hline 6044298 & LAKEHEAD UNIVERSITY & 1969 & 2002 & * & 48.430 & -89.270 & 210.3 \\
\hline 6044903 & MANITOUWADGE & 1956 & 1995 & & 49.150 & -85.800 & 332.2 \\
\hline 6044959 & MARATHON & 1945 & 1983 & * & 48.720 & -86.400 & 189.0 \\
\hline 6044961 & MARATHON A & 1989 & 1999 & & 48.760 & -86.340 & 315.5 \\
\hline 6045541 & MYRT LAKE & 1980 & 1985 & & 48.470 & -90.720 & 518.2 \\
\hline 6045676 & NOLALU SSW22 & 1979 & 1985 & & 48.100 & -89.880 & 349.9 \\
\hline 6045781 & ONE ISLAND LAKE & 1992 & 1993 & & 48.650 & -89.420 & 457.2 \\
\hline 6046767 & PUKASKWA (AUT) & 1996 & 2002 & & 48.590 & -86.290 & 207.6 \\
\hline 6046770 & PUKASKWA NATL PARK & 1983 & 2003 & & 48.600 & -86.300 & 192.0 \\
\hline 6046856 & RAITH TCPL 64 & 1970 & 1984 & & 48.730 & -89.870 & 433.1 \\
\hline 6047810 & SLATE ISLAND & 1967 & 1989 & & 48.620 & -87.000 & 185.9 \\
\hline 6048145 & STURGEON LAKE & 1973 & 1994 & * & 49.880 & -90.970 & 428.2 \\
\hline 6048230 & TERRACE BAY & 1972 & 1999 & * & 48.800 & -87.100 & 289.0 \\
\hline 6048231 & TERRACE BAY A & 1996 & 2003 & & 48.820 & -87.100 & 289.6 \\
\hline 6048261 & THUNDER BAY A & 1941 & 2003 & * & 48.370 & -89.330 & 199.0 \\
\hline 6048864 & TRANQUILLO RIDGE & 1991 & 2003 & & 48.230 & -89.520 & 335.3 \\
\hline 6049095 & UPSALA (AUT) & 1993 & 2003 & & 49.030 & -90.470 & 488.5 \\
\hline 6049098 & UPSALA TCPL 62 & 1971 & 1985 & & 49.030 & -90.520 & 492.9 \\
\hline 6049443 & WELCOME ISLAND (AUT) & 1967 & 2002 & * & 48.370 & -89.120 & 211.4 \\
\hline 6049466 & WHITEFISH LAKE & 1980 & 2003 & & 48.280 & -89.920 & 399.0 \\
\hline 6050805 & BLIND RIVER HYDRO CE & 1982 & 1989 & & 46.200 & -83.020 & 189.0 \\
\hline 6052259 & ELLIOT LAKE A & 1995 & 2003 & & 46.350 & -82.560 & 331.3 \\
\hline 6052268 & ELLIOT LAKE STANLEIG & 1984 & 1997 & & 46.420 & -82.650 & 374.0 \\
\hline 6053463 & HIGH FALLS & 1977 & 1989 & & 47.920 & -84.720 & 221.0 \\
\hline 6053570 & HORNEPAYNE & 1917 & 1989 & * & 49.230 & -84.800 & 329.2 \\
\hline 6053575 & HORNEPAYNE A & 1990 & 1995 & & 49.200 & -84.770 & 335.0 \\
\hline 6053803 & IRON BRIDGE & 1988 & 1991 & * & 46.270 & -83.350 & 198.0 \\
\hline 6055210 & MISSISSAGI ONT HYDRO & 1970 & 1997 & & 46.430 & -83.380 & 225.6 \\
\hline 6055302 & MONTREAL FALLS & 1977 & 1999 & & 47.270 & -84.430 & 306.3 \\
\hline
\end{tabular}




\begin{tabular}{|c|c|c|c|c|c|c|c|}
\hline STATION ID & STATION NAME & $\begin{array}{l}\text { START } \\
\text { YEAR }\end{array}$ & $\begin{array}{l}\text { END } \\
\text { YEAR }\end{array}$ & & LAT & LONG & $\begin{array}{l}\text { ELEV } \\
\text { (m) }\end{array}$ \\
\hline 6057590 & SAULT STE MARIE 2 & 1958 & 2002 & & 46.530 & -84.330 & 211.8 \\
\hline 6057592 & SAULT STE MARIE A & 1945 & 2003 & * & 46.480 & -84.510 & 192.0 \\
\hline 6059409 & WAWA & 1970 & 1984 & & 48.000 & -84.800 & 297.2 \\
\hline 6060070 & AGNEW MINE & 1978 & 1983 & & 46.430 & -81.620 & 305.1 \\
\hline 6060773 & BISCOTASING & 1914 & 2000 & * & 47.300 & -82.100 & 406.9 \\
\hline 6061361 & CHAPLEAU A & 1978 & 2003 & & 47.820 & -83.350 & 446.5 \\
\hline 6061850 & CONISTON STP & 1962 & 2002 & & 46.480 & -80.850 & 267.6 \\
\hline 6062860 & GOGAMA TREE NURSERY & 1989 & 1992 & & 47.680 & -81.720 & 352.0 \\
\hline 6064460 & LIVELY & 1981 & 1991 & & 46.430 & -81.150 & 282.0 \\
\hline 6065006 & MASSEY & 1983 & 2003 & & 46.180 & -82.030 & 198.0 \\
\hline 6065250 & MONETVILLE & 1963 & 2003 & & 46.140 & -80.310 & 221.0 \\
\hline 6066873 & RAMSAY & 1973 & 1983 & & 47.450 & -82.330 & 429.8 \\
\hline 6066877 & RAMSEY 2 & 1984 & 1984 & & 47.470 & -81.870 & 402.0 \\
\hline 6067308 & ST CHARLES & 1980 & 1984 & * & 46.370 & -80.520 & 235.9 \\
\hline 6068150 & SUDBURY A & 1955 & 2003 & & 46.630 & -80.800 & 347.5 \\
\hline 6068158 & SUDBURY SCIENCE NORT & 1986 & 1996 & * & 46.470 & -81.000 & 263.0 \\
\hline 6068980 & TURBINE & 1914 & 1990 & * & 46.380 & -81.570 & 205.7 \\
\hline 6069165 & WABAGISHIK & 1978 & 1988 & * & 46.320 & -81.520 & 213.4 \\
\hline 6069197 & WAHNAPITAE-STOKES & 1990 & 1991 & & 46.430 & -80.720 & 750.0 \\
\hline 6069428 & WEBBWOOD & 1983 & 1986 & & 46.270 & -81.880 & 196.0 \\
\hline 6071712 & COCHRANE & 1910 & 1993 & * & 49.070 & -81.030 & 274.9 \\
\hline 6072183 & DYMOND ONT HYDRO & 1973 & 1998 & & 47.520 & -79.680 & 198.1 \\
\hline 6072224 & EARLTON AWOS & 2001 & 2002 & & 47.700 & -79.850 & 243.4 \\
\hline 6072225 & EARLTON A & 1938 & 2003 & & 47.700 & -79.850 & 243.2 \\
\hline 6072325 & ENGLEHART & 1948 & 2000 & * & 47.820 & -79.900 & 251.5 \\
\hline 6073810 & IROQUOIS FALLS & 1913 & 1998 & & 48.750 & -80.670 & 259.1 \\
\hline 6073840 & ISLAND FALLS & 1955 & 1996 & & 49.580 & -81.380 & 213.0 \\
\hline 6073960 & KAPUSKASING CDA & 1918 & 2001 & & 49.400 & -82.430 & 217.9 \\
\hline 6073975 & KAPUSKASING A & 1937 & 2003 & & 49.410 & -82.470 & 226.5 \\
\hline 6073980 & KAPUSKASING CDA ON & 2000 & 2003 & & 49.410 & -82.440 & 218.0 \\
\hline 6074209 & KIRKLAND LAKE & 1950 & 1996 & * & 48.150 & -80.000 & 324.0 \\
\hline 6074211 & KIRKLAND LAKE CS & 1997 & 2003 & & 48.150 & -80.000 & 324.0 \\
\hline 6075013 & MATHESON ONT HYDRO & 1983 & 1992 & & 48.530 & -80.470 & 274.0 \\
\hline 6075024 & MATTICE TCPL & 1967 & 1995 & & 49.600 & -83.170 & 233.2 \\
\hline 6075543 & NAGAGAMI (AUT) & 1993 & 2003 & & 49.750 & -84.160 & 264.0 \\
\hline 6075594 & NEW LISKEARD & 1924 & 1983 & * & 47.500 & -79.670 & 194.2 \\
\hline 6076572 & PORCUPINE ONT HYDRO & 1969 & 2001 & & 48.470 & -81.270 & 298.7 \\
\hline 6077845 & SMOKY FALLS & 1934 & 1997 & & 50.070 & -82.170 & 182.9 \\
\hline 6078285 & TIMMINS A & 1955 & 2003 & & 48.570 & -81.380 & 294.7 \\
\hline 6081928 & CRYSTAL FALLS & 1922 & 1988 & * & 46.450 & -79.870 & 227.1 \\
\hline
\end{tabular}




\begin{tabular}{|c|c|}
\hline STATION ID & STATION NAME \\
\hline 6082612 & FRENCH R CHAUDIERE D \\
\hline 6088144 & STURGEON FALLS \\
\hline 6092915 & GORE BAY \\
\hline 6092925 & GORE BAY A \\
\hline 6093004 & GREAT DUCK ISLAND \\
\hline 6094449 & LITTLE CURRENT \\
\hline 6097426 & SANDFIELD \\
\hline 6097915 & SOUTH BAYMOUTH \\
\hline 6121912 & COVE ISLAND \\
\hline 6121940 & CYPRUS LAKE CS \\
\hline 6128320 & TOBERMORY \\
\hline 6128323 & TOBERMORY CYPRUS LAK \\
\hline 6020LPQ & ATIKOKAN (AUT) \\
\hline $602 \mathrm{~B} 300$ & EMO HOSKINS \\
\hline 602FQ5L & RAINY RIVER-COOPER \\
\hline $602 \mathrm{~K} 300$ & EMO RADBOURNE \\
\hline $6042 \mathrm{MJ} 7$ & FLINT \\
\hline 6048K6J & THUNDER BAY MCS CENT \\
\hline $604 \mathrm{H} 26 \mathrm{~A}$ & THUNDER BAY POMBER \\
\hline 604HBFA & THUNDER BAY WPCP \\
\hline $604 \mathrm{HK} 61$ & THUNDER BAY PROVINCI \\
\hline 6045003 & THUNDER BAY A FIREHA \\
\hline 6050NNP & BAR RIVER \\
\hline 6059D09 & WAWA A \\
\hline $6069 K 90$ & WARREN \\
\hline 6070QK6 & BONNER LAKE \\
\hline 608A06G & CACHE BAY \\
\hline
\end{tabular}

$\begin{array}{llllll}\text { START } & \text { END } & & & & \text { ELEV } \\ \text { YEAR } & \text { YEAR } & & \text { LAT } & \text { LONG } & (\mathrm{m}) \\ 1970 & 2003 & & 46.130 & -80.020 & 198.1 \\ 1884 & 2002 & * & 46.370 & -79.930 & 201.0 \\ 1881 & 1983 & * & 45.920 & -82.470 & 190.5 \\ 1947 & 2002 & & 45.880 & -82.570 & 193.5 \\ 1966 & 1985 & & 45.650 & -82.970 & 182.9 \\ 1986 & 1989 & & 45.970 & -81.920 & 190.5 \\ 1998 & 2003 & & 45.680 & -81.980 & 229.0 \\ 1954 & 1993 & & 45.580 & -82.020 & 181.7 \\ 1965 & 1985 & * & 45.330 & -81.730 & 179.8 \\ 1995 & 2003 & & 45.230 & -81.530 & 190.0 \\ 1888 & 1983 & * & 45.250 & -81.670 & 182.9 \\ 1988 & 1994 & & 45.230 & -81.530 & 190.0 \\ 2000 & 2003 & & 48.760 & -91.630 & 389.3 \\ 1979 & 1993 & * & 48.750 & -93.850 & 351.1 \\ 1991 & 1993 & & 48.730 & -94.620 & 323.0 \\ 1979 & 2002 & * & 48.680 & -93.830 & 350.0 \\ 1979 & 2003 & & 48.350 & -89.680 & 274.0 \\ 1980 & 1983 & * & 48.320 & -89.380 & 231.6 \\ 1980 & 1987 & & 48.500 & -89.220 & 228.9 \\ 1961 & 1989 & & 48.400 & -89.230 & 184.4 \\ 1990 & 1990 & & 48.450 & -89.170 & 184.4 \\ 1995 & 1996 & & 48.370 & -89.320 & 199.0 \\ 1988 & 1992 & * & 46.430 & -84.050 & 180.0 \\ 1977 & 2003 & & 47.970 & -84.780 & 287.1 \\ 1987 & 1998 & & 46.430 & -80.320 & 212.0 \\ 1990 & 2003 & & 49.380 & -82.120 & 245.0 \\ 1981 & 1985 & & 46.380 & -80.020 & 198.1\end{array}$




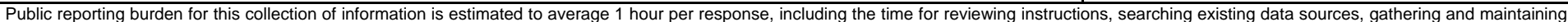

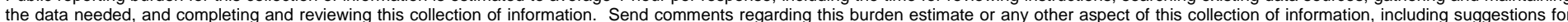

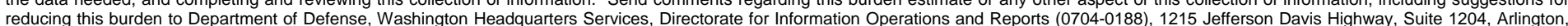

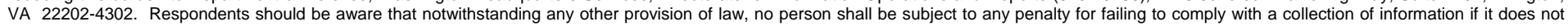
display a currently valid OMB control number. PLEASE DO NOT RETURN YOUR FORM TO THE ABOVE ADDRESS.

\begin{tabular}{l|l} 
1. REPORT DATE (DD-MM-YYYY) & 2. REPORT TYPE \\
May 2007 & Technical Report
\end{tabular}

4. TITLE AND SUBTITLE

Analysis of the Lake Superior Watershed Seasonal Snow Cover

6. AUTHOR(S)

Steven F. Daly, Timothy B. Baldwin, and Patricia Weyrick
3. DATES COVERED (From - To)

5a. CONTRACT NUMBER

5b. GRANT NUMBER

5c. PROGRAM ELEMENT NUMBER

5d. PROJECT NUMBER

5e. TASK NUMBER

5f. WORK UNIT NUMBER

8. PERFORMING ORGANIZATION REPORT NUMBER

ERDC/CRREL TR-07-5

U.S. Army Engineer Research and Development Center

Cold Regions Research and Engineering Laboratory

72 Lyme Road

Hanover, NH 03755-1290

9. SPONSORING / MONITORING AGENCY NAME(S) AND ADDRESS(ES)

Detroit District, U.S. Army Corps of Engineers

10. SPONSOR/MONITOR'S ACRONYM(S)

11. SPONSOR/MONITOR'S REPORT NUMBER(S)

\section{DISTRIBUTION / AVAILABILITY STATEMENT}

Approved for public release; distribution is unlimited.

Available from NTIS, Springfield, Virginia 22161.

13. SUPPLEMENTARY NOTES

\section{ABSTRACT}

Daily estimates of the snow water equivalent (SWE) distribution for the period from 1 December through 30 April for each winter season from 1979-80 through 2002-03 were calculated for the entire Lake Superior watershed. The calculations were based on numerous ground-based daily observations collected and compiled by the National Weather Service in the United States and by the Meteorological Service of Canada in Canada. The daily estimates of SWE were then used to determine the annual accumulation and melt period characteristics of the Lake Superior watershed, along with the annual series of maximum SWE volume and the incremental accumulated SWE volume. Selected results are also shown for the individual sub-basins. Maps were also prepared of the mean SWE distributions on the 1st and 15th day of each winter month.

\section{SUBJECT TERMS}

Lake Superior

Snow cover

16. SECURITY CLASSIFICATION OF:

\section{Snow water equivalent}

(16.

a. REPORT

$\mathrm{U}$ b. ABSTRACT

U
17. LIMITATION OF ABSTRACT

c. THIS PAGE
U
18. NUMBER OF PAGES

55 19a. NAME OF RESPONSIBLE PERSON

19b. TELEPHONE NUMBER (include area code) 